\title{
Sustainable Development
}

in Government

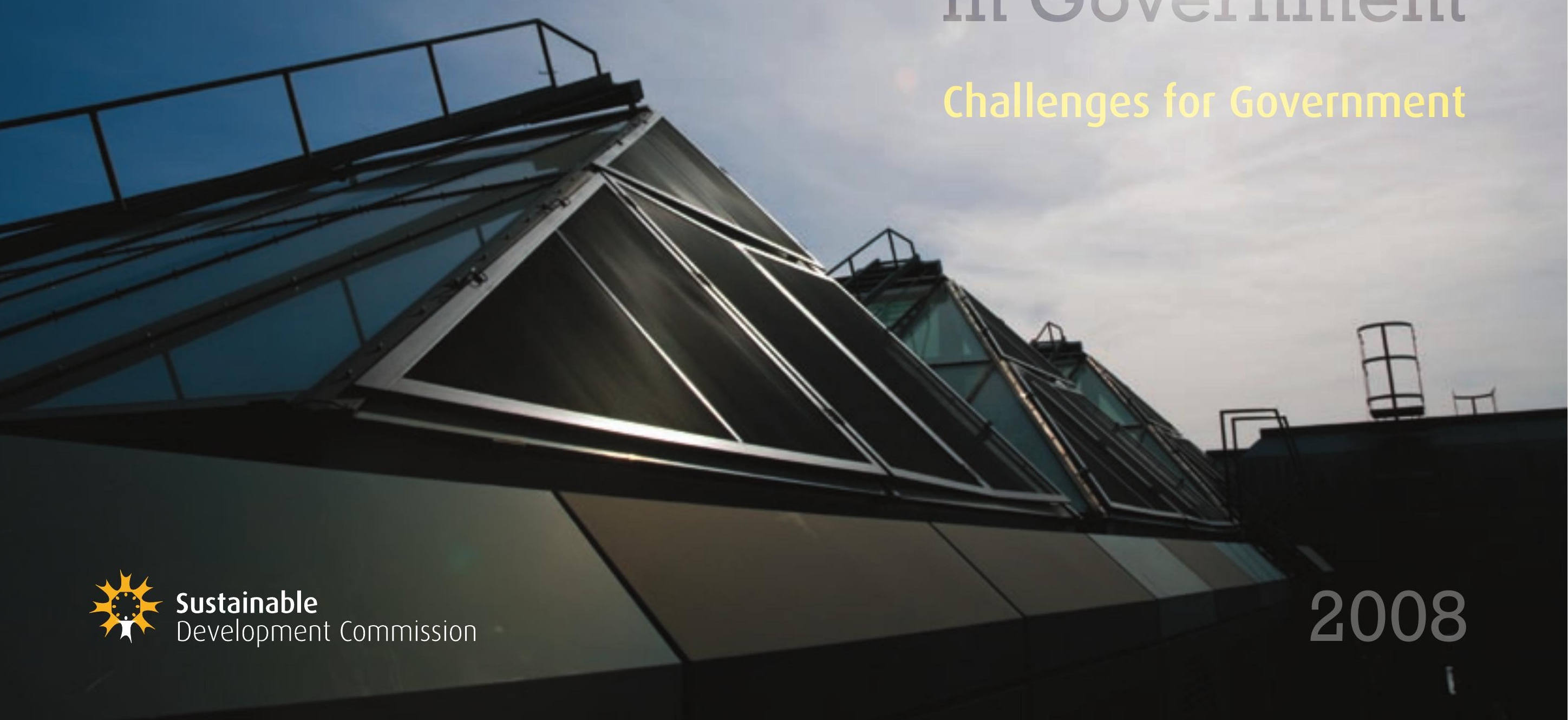




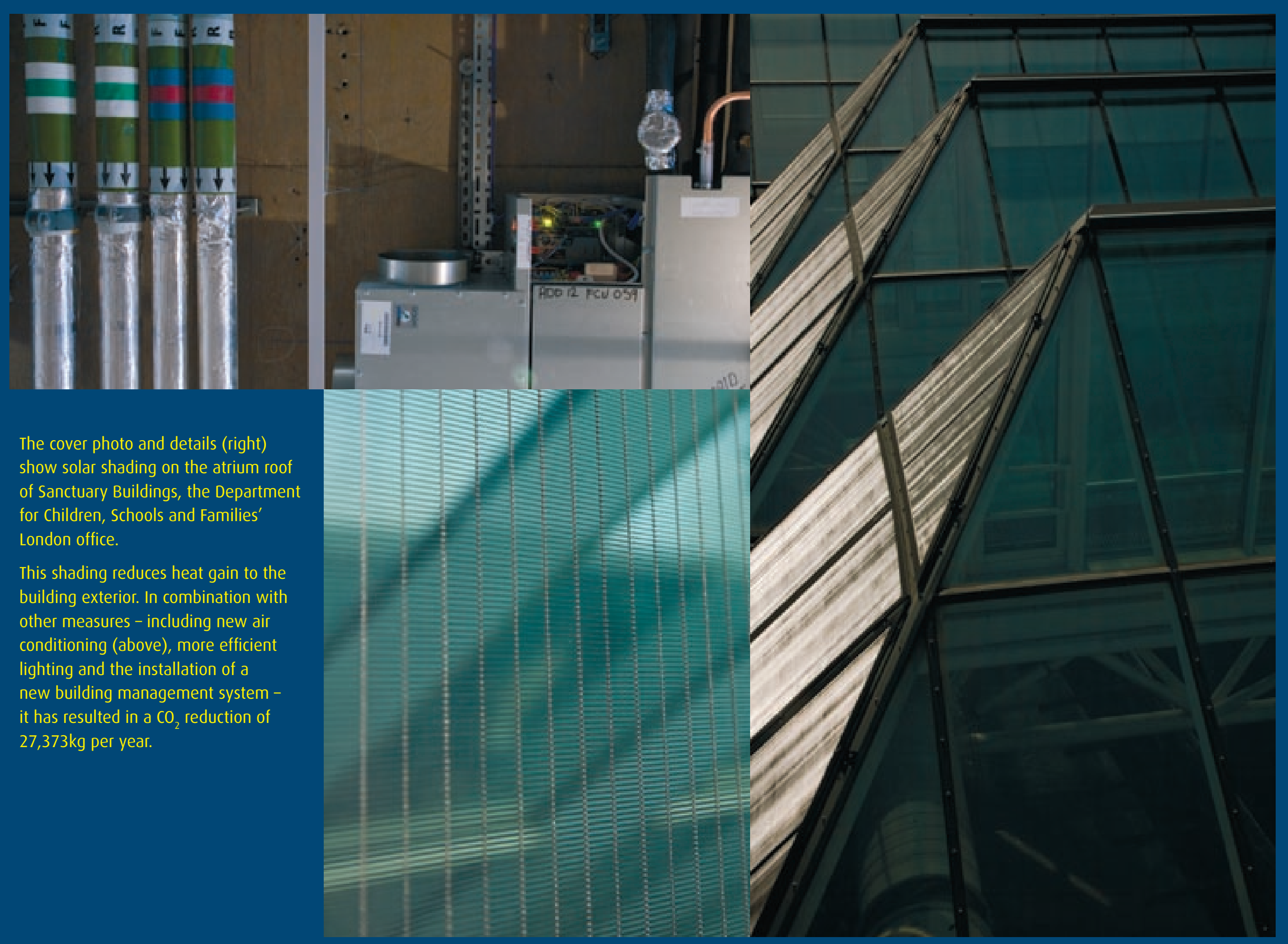




\section{Sustainable Development in Government 2008}

Challenges for Government 


\section{List of Figures}

Figure 1 Structure for analysis of the three thematic areas

Figure 2 Percentage contribution to pan government carbon emissions from offices

Figure 3 Reported carbon sources from the SDiG process 2007/08 (tonnes of carbon)

Figure 4 Comparison of energy sourced from fossil fuels and electricity between the baseline year and 2007/08 (kWh/m²)

Figure 5 Total percentage of electricity derived from renewable sources and Combined Heat and Power (CHP)

Figure 6 Percentage of government buildings at each Display Energy Certificate (DEC) rating

Figure 7 Percentage of government travel by road, rail and air (mileage)

Figure 8 Distribution of car engine sizes and fuel types across the government fleet 2007/08

Figure 9 Percentage of total waste arisings reported for $2007 / 08$

Figure 10 Pan government changes in levels of waste arisings and recycling (tonnes) from the baseline year

Figure 11 Total water consumption $\left(\mathrm{m}^{3}\right)$ from office and non-office locations for 2007/08

Figure 12 Total water consumption $\left(\mathrm{m}^{3}\right)$ from office and non-office locations in 2007/08 per FTE

Figure 13 Percentage of SSSI area in target condition

Figure 14 Proportion of total government land holdings designated as SSSI and included in SOGE targets

\section{List of Boxes}

Box 1 Key findings - Pan-government against the SOGE Targets

Box 2 Key findings - Pan-government against the Mandated Mechanisms

Box 3 Key findings - Pan-government against the SPAP Commitments

\section{List of Tables}

Table 1 Potential for Wind and PV on the UK Government estate

Table 2 Star rating scoring thresholds

Table 3 Traffic light indicators for performance against the SOGE targets

Table 4 Pan-government SOGE performance star rating

Table 5 Traffic light indicators of pan-government performance against the SOGE targets

Table 6 Traffic light indicators for mechanisms and SPAP commitments

Table 7 Pan-government mechanisms star rating

Table 8 Traffic light indicators of pan-government performance against the Mandated Mechanisms

Table 9 Pan-government performance star rating against the SPAP commitments

Table 10 Traffic light indicators of pan-government performance against the SPAP commitments

\section{Abbreviations}

BERR Department for Business, Enterprise and Regulatory Reform

BRE Building Research Establishment

BREEAM Building Research Establishment Environmental Assessment Method

BWEA British Wind Energy Association

CCC Committee on Climate Change

CESP Centre of Expertise in Sustainable Procurement

CHP Combined Heat and Power

CHPQA Combined Heat and Power Quality Assurance

CLG Department for Communities and Local Government

co Cabinet Office

$\mathrm{CO}_{2}$ Carbon dioxide

CRC Carbon Reduction Commitment

CSL Central Science Laboratory

DA Devolved Administration

DCMS Department for Culture, Media and Sport

DCSF Department for Children, Schools and Families

DEC Display Energy Certificate

DECC Department for Energy and Climate Change

Defra Department for Environment, Food and Rural Affairs
DFID Department for International Development

DfT Department for Transport

DH Department for Health

DIUS Department for Innovation, Universities and Skills DWP Department for Work and Pensions

EA Executive Agency

ECGD Export Credits Guarantee Department

EMS Environmental Management System

e-PIMS Electronic Property Information Mapping Service

EU European Union

FSA Food Standards Agency

FCO Foreign and Commonwealth office

FC Forestry Commission

FTE Full Time Equivalent

GB Great Britain

GCOF Government Carbon Offsetting Fund

GCTC Good Vehicle Testing Station

HMRC Her Majesty's Revenue and Customs

HMT Her Majesty's Treasury

HO Home Office

ICT Information and Communications Technology

LCVPP Low Carbon Vehicle Procurement Programme

LOD Law Officer's Department

MOD Ministry of Defence

MOJ Ministry of Justice

MOU Memorandum of Understanding

NDPB Non Departmental Public Body

OGC Office of Government Commerce

ONS Office for National Statistics

RAG Red, Amber and Green

RAG+ Red, Amber, Green and Blue

SCP Sustainable Consumption and Production

SDC Sustainable Development Commission

SDGE Sustainable Development on the Government Estate

SDiG Sustainable Development in Government

SOGE Sustainable Operations on the Government Estate

SPAP Sustainable Procurement Action Plan

SPTF Sustainable Procurement Task Force

SSSI Site of Special Scientific Interest

UK United Kingdom

VOSA Vehicle and Operator Services Agency 


\section{Contents}

Foreword

(1) Introduction

- Government commitments and targets

- About this report

- Report Structure

- Future intentions

2 Thematic Area Analysis

- Carbon

- Energy

- Travel

- Waste

- Water

- Biodiversity

3 SOGE Framework Performance Assessment -

SOGE Targets, Mandated Mechanisms and SPAP Commitments

How is government performing overall against the SOGE targets?

- Star Rating

- Traffic Lights

- Key Findings

Are departments using the tools/mechanisms in place to support performance improvement against the SOGE targets?

- Mechanisms Star Rating

- Traffic Lights

- Key Findings

To what extent are departments meeting the commitments

set out in the Sustainable Procurement Action Plan?

- SPAP Commitments Star Rating

- Traffic Lights

- Key Findings
4 Cross-cutting Issues and Findings

- Sustainable Development Reporting and Governance

- The SOGE Framework

- Data Issues

- Review of the SOGE Framework

- Wider Issues

\section{Summary of Issues and Recommendations}

- SDiG 08 - Issues and Recommendations map

- SDiG 08 - Issues and Recommendations table

\section{Annexes}

- Annex A - SOGE Framework

- Annex B - Case studies

- Annex C - SDiG scoring methodology

- Annex D - Assumptions for self-generated renewables on the government estate recommendation 



\section{Foreword}

\section{"We can now build a new green economy. Rise to one of the greatest peace time challenges of all, that will not only help our country prosper, but will build a better, more secure and more sustainable world."}

Gordon Brown

Low-carbon Industrial Summit, March 2009
The government understands the severity of the climate crisis, and the necessity of living within environmental limits. It also understands the benefits to be gained from a transition to a sustainable economy: the jobs created in environmental services, the social benefits of improving housing and reducing fuel poverty, the health benefits of good-quality green space. And it understands that the shift to a sustainable future must begin at home, with the government's own estate.

Government can have a significant impact on sustainability through managing its own business well: reducing carbon, managing biodiversity, promoting good employment practices. Its policies, designed to encourage businesses and individuals to act, need to be reinforced through practical action and leadership by government.

The Sustainable Development Commission has in past years been very critical of government's performance against its own sustainability targets. Although Ministers have always accepted the need to lead by example, delivery has lagged some way behind. In response to our criticisms, considerable efforts are now being made to improve performance. A new Centre of Expertise in Sustainable Procurement has been established, to provide co-ordination, help and guidance on sustainable operations and procurement. Permanent Secretaries are now held to account for their department's performance.

The results are beginning to show. As this report makes clear, government is doing better than ever, and has reduced waste, water consumption and emissions from road travel, for example. This is undoubtedly due to the hard work of dedicated practitioners in departments and across government. But it is still not on track to meet some crucial targets, including goals on carbon reduction for offices.

And the targets themselves don't match the scale of the challenge we face, particularly on climate change. Targets for carbon reduction and renewable energy use on the government estate do not match up to the national goal of $80 \%$ carbon emission reductions by 2050 . Although road travel has been reduced, this has not been linked to a more general shift toward more sustainable travel options - rail instead of air; or reducing the need to travel through better use of video-conferencing.

In this assessment, we report on government's progress against targets, but we also recommend ways to look beyond the targets at sustainability issues which affect the entire world and make real progress in six crucial areas: carbon, energy, travel, waste, water and biodiversity. The aim of this report is to highlight future challenges for government. Our recommendations are based on the data, dialogue with practitioners across government, and experience of progress elsewhere, in the business sector, for example.

Government has made real progress in meeting its own sustainability goals. We look forward to working collaboratively to ensure that it plays its own part in the transition to a sustainable society.

Rebecca Willis

Vice-Chair, Sustainable Development Commission 

S. 1 For

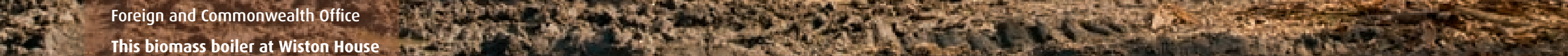
H.:- This biomass boiler at Wiston House th W. 1 is is fuelled with wood chip taken
from the surrounding woodland.

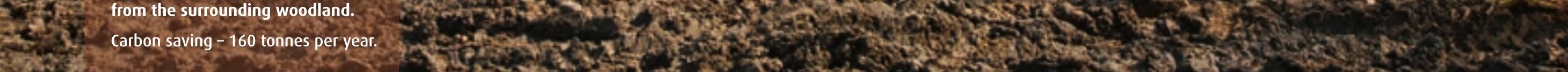


The UK government is committed to leading by example on sustainable development. Its 2005 Strategy, Securing the Future ${ }^{l}$, sets out a long-term vision for sustainable development in the UK. As the Strategy points out, the UK is living beyond its means: "From the loss of biodiversity ... to the negative effect our consumption patterns are having on the environment and the climate, our way of life is placing an increasing burden on the planet." The most urgent manifestation of this is, of course, climate change, and the UK has positioned itself as a leader on the global efforts to tackle carbon emissions.

\section{Government commitments and targets}

Sustainability begins at home, and the UK government has a duty to lead by example, to inspire and encourage the changes needed to achieve sustainable development. For central government, this means getting to grips with its own performance, including the way it powers its buildings, how its staff travel, the amount of waste it produces and how this waste is managed, the water it consumes and its responsibility as a steward for the biodiversity across its considerable landholdings. The government's influence and responsibility beyond its estate means that it must carefully consider the impacts of the money it spends.
The Sustainable Development Commission (SDC) is the UK government's independent adviser and watchdog on sustainable development, ${ }^{2}$ and as such has a duty to report on government's own sustainability performance. This publication, the annual Sustainable Development in Government (SDiG) report, assesses government operations and procurement practices. It sets out how well the government is meeting its targets and highlights future challenges for government.

The government believes that the management of its own estate should be an exemplar for the whole of the UK. ${ }^{3}$ In the government's own words, "a sustainably managed estate" is one that has:

- modern, resource efficient, low energy usage buildings

- well conserved and managed land 


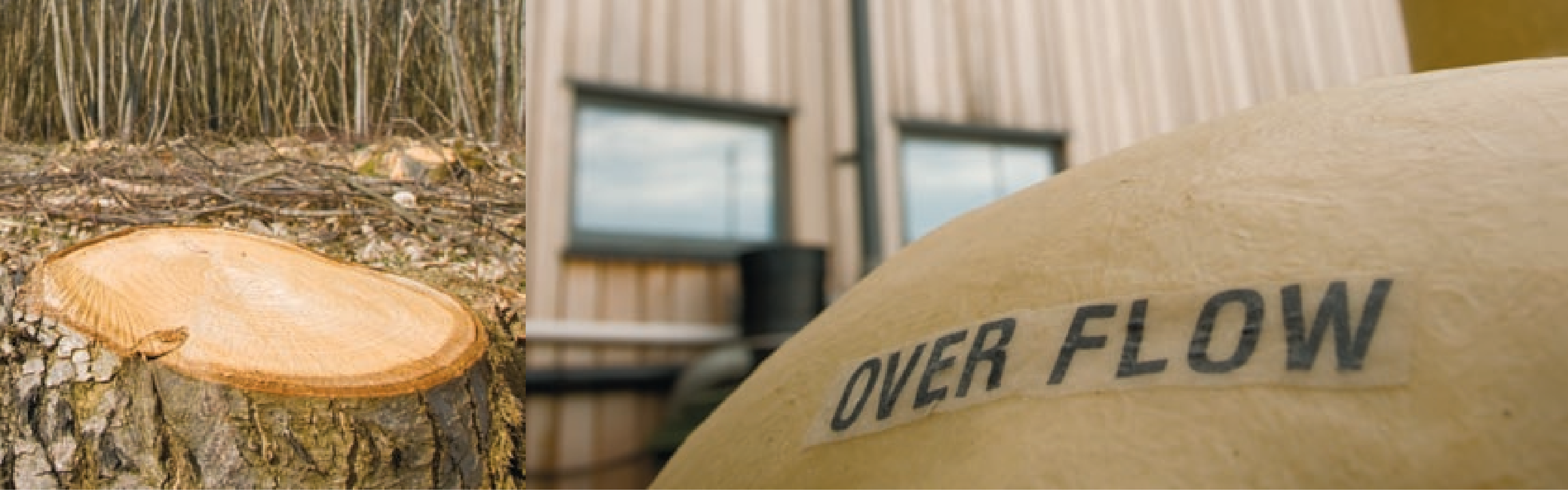

- efficient use of space and ways of working

- the principles of sustainable development embedded into working practices. ${ }^{4}$

It further notes that "sustainable operations are wholly consistent with good value for money and efficiency, and are part of building a modern and resource efficient public sector." ${ }^{15}$

This report is part of an assessment process which examines central government's performance on operations and procurement, as set out in the Framework for Sustainable Operations on the Government Estate (SOGE). ${ }^{6}$ It is based on data provided by departments for the period 2007/08.
The SOGE Framework consists of three elements:

1 SOGE Targets - 14 targets overall, including targets on reducing carbon emissions from offices and road vehicles, reducing waste arisings and water consumption, and improving energy efficiency, recycling rates and biodiversity. ${ }^{7}$ There are two additional targets carried forward from the former Sustainable Development on the Government Estate (SDGE) framework, ${ }^{8}$ as targets had not been reached. These targets relate to acquiring electricity from renewable and combined heat and power (CHP) sources.

2 Mandated Mechanisms - Departments have been asked to use certain mechanisms and processes to help them improve performance. These 'mandated mechanisms' include sustainability appraisals of office relocations; applying the Building Research Establishment Environmental Assessment Method

(BREEAM) standards 9 to new builds or major refurbishments, and using formal Environmental Management Systems (EMS).

3 Commitments from the Sustainable Procurement Action Plan (SPAP) - the SPAP is government's action plan for embedding sustainability in its procurement practices. The commitments cover leadership and accountability on sustainable procurement, budgeting and accounting practice, building capacity, raising standards and supplier engagement.

For full details of the SOGE Framework see Annex A. 
Government as a whole has made significant steps towards reducing waste, water consumption and emissions from road travel, achieving a rating of 4 stars out of 5 against the SDC's star rating methodology (compared to 3 out of 5 last year). Please refer to Chapter 3 for further information on the star ratings. The SDC recognises the hard work by practitioners across government that is behind this progress. However, while carbon emissions from offices show an improvement from both the baseline year of 1999/00 and from 2006/07, they are still not falling fast enough to meet the target of a $12.5 \%$ reduction by 2011/12. And while recycling and electricity sourced from renewables are both on track to meet targets, both are down on last year's totals.

For further information on performance please see our SDiG 08 assessment on our website: www.sd-commission.org.uk/sdig2008/
Since last year's report, the SDC has worked closely with government to improve internal governance structures and capabilities for delivery. Responding to recommendations made by the SDC, the government announced a new Centre of Expertise in Sustainable Procurement (CESP) within the office of Government Commerce (OGC), and also appointed a Chief Sustainability officer to lead this agenda in government. CESP is tasked with ensuring appropriate government action and delivery around sustainable operations and procurement. CESP produced a government operations and procurement Delivery Plan in August 2008. The Delivery Plan set out the trajectories and initiatives government and departments have developed to achieve the SOGE targets. The SDC provided support and advice during the drafting of the Plan. The Permanent Secretaries of the government departments also now have sustainable operations targets in their personal objectives, which has helped raise the priority level of this agenda across government.

CESP's future work programme promises to drive further improvements within departments and across government, and the SDC welcomes these initiatives as encouraging signs of strong leadership and support. Some examples include:

- Guidance for departments on the coordination of the Carbon Reduction Commitment (CRC)

- A departmental focused support programme targeted specifically at areas where focus is needed to meet 2010/11 commitments

- Development of a cross-government energy efficiency retrofit programme 


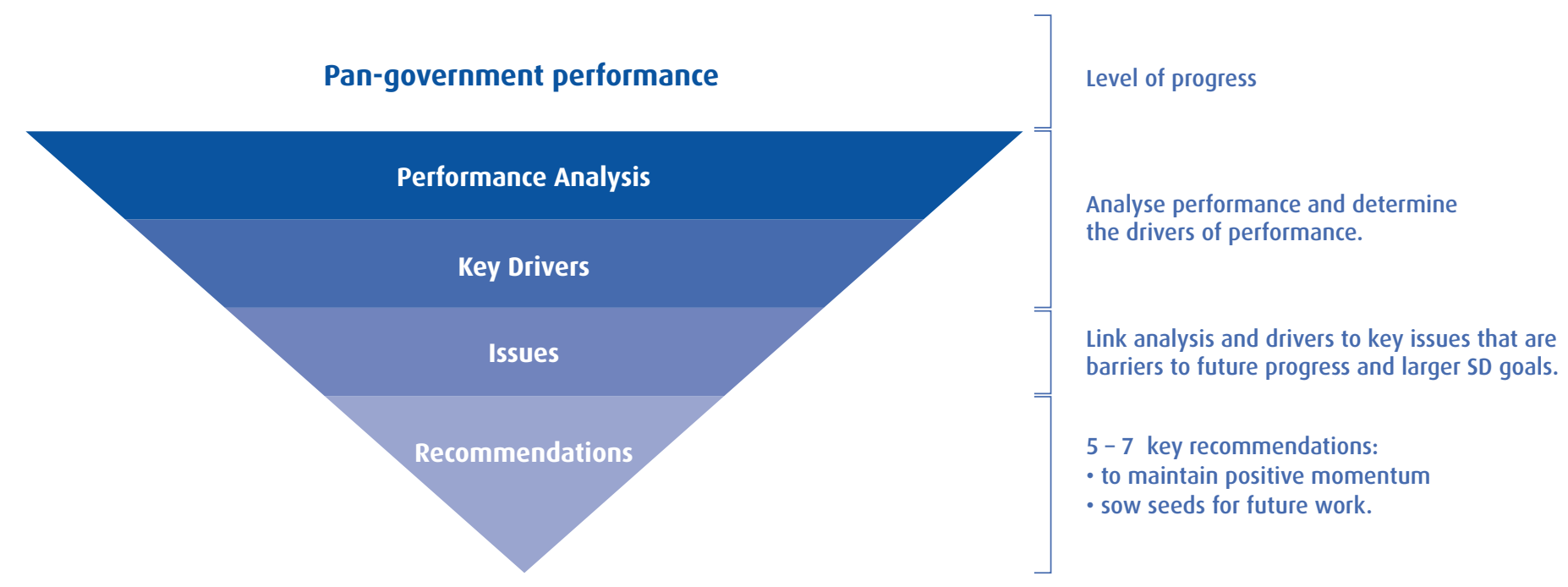

\section{Report Structure}

Chapter 2 takes a detailed look at six areas of government performance relating to the SOGE targets. These areas are:
- Carbon
- Waste
- Energy
- Water
- Travel
- Biodiversity

For each area, we assess government's performance against the relevant SOGE targets, drill down into the reasons why performance is as reported, and identify the specific issues and challenges. Each section ends with specific recommendations for future improvements. A short summary of each case study relevant to the thematic areas is also provided; for full case studies see Annex B.

Chapter 3 provides a summary of overall government performance against the SOGE Framework. While this report is focused primarily on assessing government's performance against the SOGE targets as the operational outcomes for government, government's performance against the mandated mechanisms and Sustainable Procurement Action Plan (SPAP) commitments is also briefly examined. This section assesses how government is using the tools and initiatives at its disposal to improve its performance against the sustainable operations agenda and whether government is meeting the commitments as set out in the SPAP.

Chapter 4 discusses related performance findings from the SDiG process itself (e.g. data quality and coverage) and highlights cross-cutting issues within the current SOGE Framework and from the current process.

Chapter 5 summarises the issues and recommendations highlighted in Chapters 2 and 4. These are presented both as a table and as a map which shows the linkages and relationships between the issues and the corresponding recommendations.

\section{Future intentions}

One of our key recommendations is the need for government and all its departments, agencies, non departmental public bodies (NDPBs) and other bodies to understand their carbon footprint, thus enabling them to manage and minimise the carbon impacts of all their operations and key procurement activities. Reducing carbon emissions and dealing with climate change are by no means the totality of sustainable development; however the transformation to a low carbon economy and society must be at the centre of a sustainable vision. For the SDiG 09 report next year the SDC will explore the feasibility and usefulness of producing a carbon footprint of government to aid in understanding carbon impacts, identifying priority areas for reductions and building greater understanding of footprinting methodologies. 

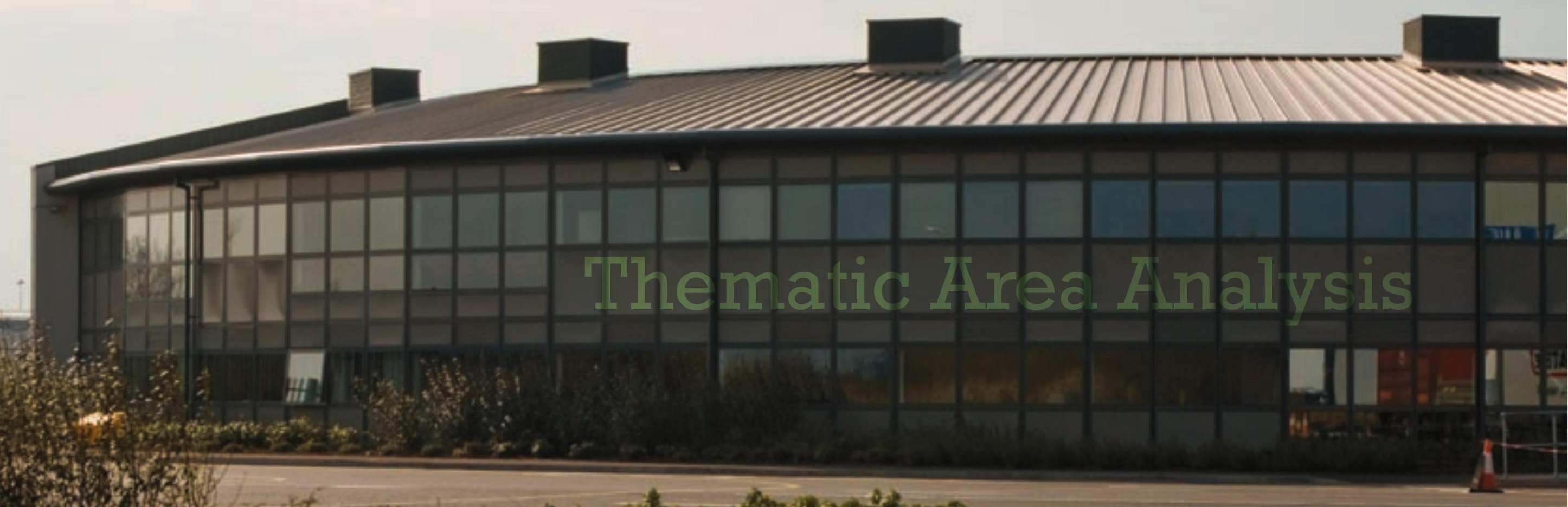

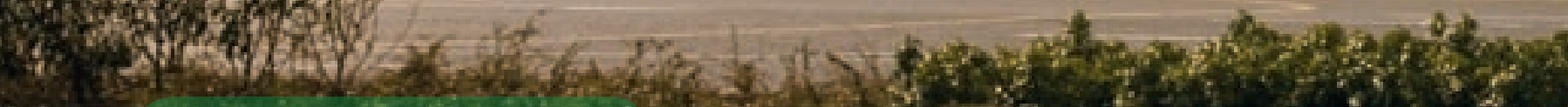

Vehicle and Operator Services Agency

This Goods Vehicle Testing Station generates electricity from its solar

panels, reduces water consumption

through a rainwater-harvesting

system, and minimises energy

use by heating and cooling with a

continual air flow system. 


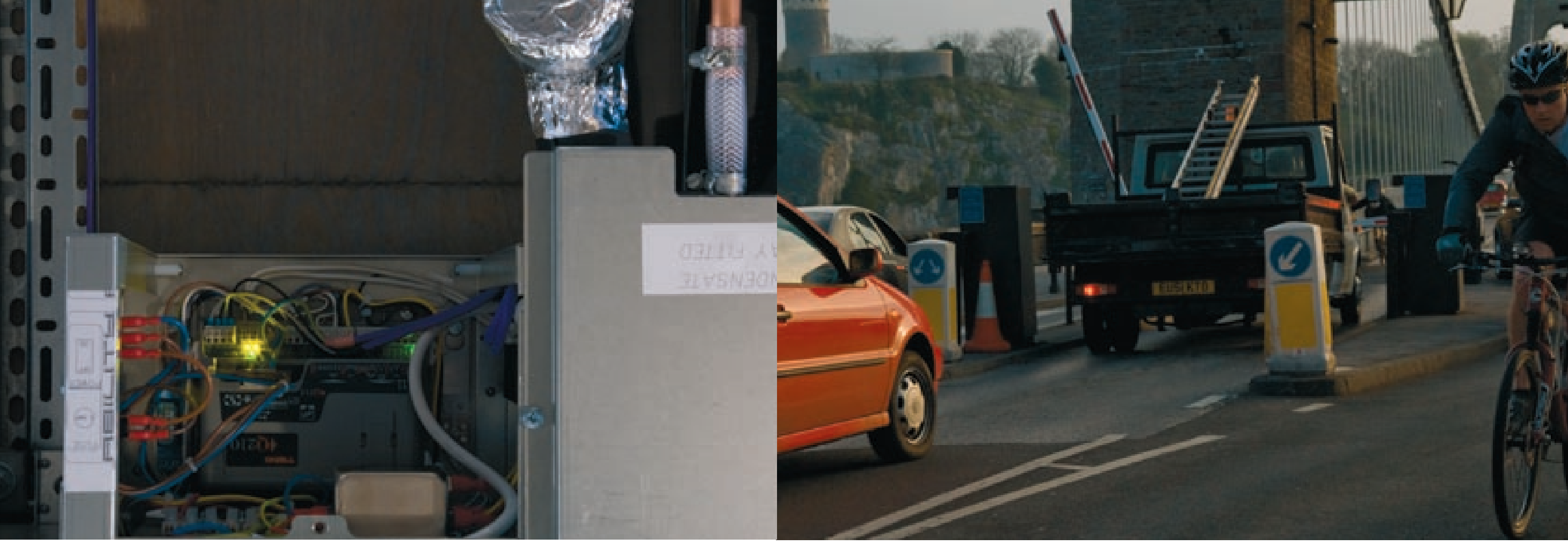

\section{Carbon}

The latest science tells us that the UK will have to reduce its carbon emissions by more than the current commitment of $\mathbf{8 0} \%$ by $\mathbf{2 0 5 0}$ if there is to be any hope of minimising the effects of climate change and allowing much needed development elsewhere in the world. As the effects of climate change are dependent on the cumulative carbon emissions in the atmosphere, the issue is not just whether we reach the 2050 target, but also how we get there. In other words, we must make early carbon reductions. ${ }^{10}$ The role of the government is crucial in creating the right policy framework to drive the scale and speed of transformation needed in society. Whilst government's direct emissions are a small fraction of the total, it needs to lead by example. The new carbon budgets for the UK established in the Climate Change Act could be undermined if government does not tackle its own emissions.

All aspects of government operations (e.g. energy use, travel, waste arisings, water use, land management and procurement) are likely to have a carbon impact, either directly or indirectly. Two sources of carbon emissions are assessed against government's own targets: offices and road-based administrative travel, which together are responsible for the highest amount of carbon emissions. The current targets do not, therefore, take into account the carbon impacts of government's other activities, such as rail and air travel and non-office sites on its estate, despite the potential for significant reduction in these areas.

\section{Performance against targets}

Offices target

Departments to reduce carbon emissions from offices by $12.5 \%$ by $2010 / 11$, relative to $1999 / 2000$ levels.

- Government reported a reduction of $6.3 \%$ in carbon emissions from offices since the baseline year

- Whilst this is an improvement of 2.3\% from 2006/7, government is still not on track to meet its carbon emissions from offices target. The rate of reduction must be accelerated. 


\section{Figure 2 Percentage contribution to pan-government carbon emissions from offices}

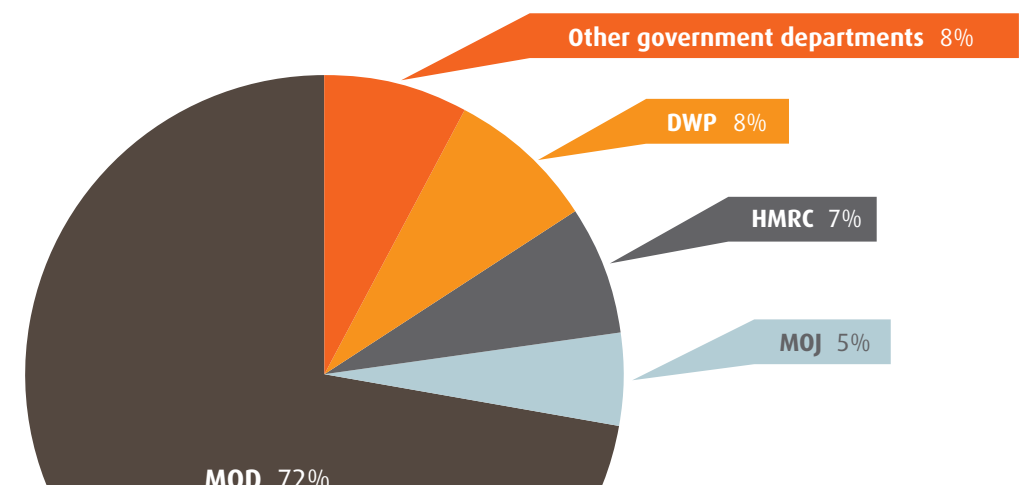

MOD $72 \%$

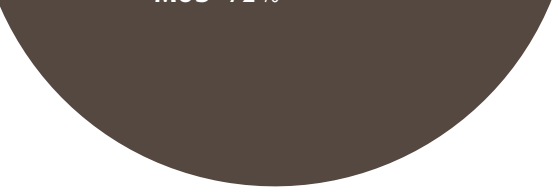

\section{Vehicles target}

Departments to reduce carbon emissions from road vehicles used for government administrative operations by $15 \%$ by $2010 / 11$, relative to $2005 / 06$ levels.

- Government reported a reduction in carbon emissions from road vehicles of $\mathbf{1 0 . 3} \%$ since the baseline year

- This is an excellent improvement on 2006/07 results (which demonstrated a 1.5\% increase), and also means that government is on track to meet its target.

\section{What is driving carbon performance?}

- The Ministry of Defence accounts for $72 \%$ of reported carbon emissions (Figure 2); however the MOD reports on non-offices as well as offices. Although MOD's carbon emissions are higher this year than those reported in 2006/07, last year's figures included the privatised research laboratory, QinetiQ. Therefore, MOD's 2007/08 performance still shows an improvement compared to the 1999/00 baseline year (a 10.3\% decrease) as well as an improvement from 2006/07 once QinetiQ is removed and a more accurate comparison is available (MOD's 2006/07 performance falls from an $11.6 \%$ carbon emissions reduction to a $7.7 \%$ reduction once QinetiQ is removed). In contrast, carbon emissions from the civil estate (non-MOD) remain above that of the baseline year. Despite the continued poor performance of the civil estate relative to the baseline year, this year's performance has improved compared to last year (a reduction from a $22 \%$ increase in carbon emissions from the baseline last year compared to a $5.3 \%$ increase this year against the baseline year). This offsets the slight worsening of MOD's performance, and accounts for the pangovernment improvement from last year.

- DWP, HMRC and MOJ together account for approximately $20 \%$ of civil estate carbon emissions from offices (Figure 2). While all three are still not on track to meet the target, all three have reported considerable improvements when compared to 2006/07. However, these improvements are driven by either adjustments to the baselines in the case of DWP and HMRC, or considerably better data quality in the case of MOJ. The rebaselining was for valid and acceptable reasons and allows for a more accurate picture of performance.

- Historically, data quality has been poor. This year, the SDiG process included an extensive baseline adjustment exercise to ensure comparability and better quality data. For example, the privatisation of QinetiQ resulted in a one-off "windfall" and skewed figures in SDIG 07..$^{11}$ These figures have now been removed from baseline data.

- Government has made good progress on reducing carbon emissions from heating and fossil fuels (a 22.5\% reduction). However, this is offset by poor performance on reducing carbon emissions from electricity (a 3\% increase).

This is particularly a concern for the civil estate where carbon emissions from electricity have risen by $16 \%$ since the baseline. For further information on this issue, see the Energy thematic area analysis. 


\section{Issues}

- The government is not leading by example, ${ }^{12}$ or contributing enough to UK wide emissions reduction targets, as it is not currently on track to meet its own target for carbon emissions from offices.

- The full carbon impact of government's operations and procurement, including the supply chain, has not been quantified. Full and accurate carbon footprinting is essential if emissions are to be reduced and sustainability goals are to be achieved.

- Government has reported that it produces $42,356 \mathrm{kWh}$ of electricity and $832,131 \mathrm{kWh}$ of heat from self-generated renewable sources. The electricity is from photovoltaics (322 kWh) on the MOD Defence Estates, and wind power (42,034 kWh) in three departments: DfT, MOJ and MOD (Defence Estates). The heat is from biomass at FCO (378,560 kWh), and from solar water heating by the MOD Navy and Army $(453,571 \mathrm{kWh})$. This means that energy from self-generated renewables is just a tiny fraction of overall energy consumption, less than $0.01 \%$. This does not include any energy from CHP.

- Government has committed all departments to participate in the Carbon Reduction Commitment (CRC), a legally binding climate change and energy saving scheme in which organisations have to measure their carbon emissions and pledge reductions. They can trade - selling surplus reductions to others, or buying credits if they produce too much carbon. The scheme extends much further into the public sector as school, hospitals, prisons and local authorities will also be included. While government is planning to produce guidance for departments, at the moment there is little understanding of the implications of the scheme. The baseline for the CRC is the same year as the target year for the interim SOGE target, which means departments may already have achieved early carbon reductions, and may therefore have a more difficult starting point. Poor performance by public sector organisations in the scheme will result in the loss of large sums of public money to the other organisations in the CRC who may be starting from an easier starting point; this includes the private sector.

- Despite ministerial approval for a renewed contract for the Government Carbon offsetting Fund (GCOF), a clear stance on carbon neutrality and carbon offsetting is still lacking. Given this current lack of clarity, the current commitment for the central government office estate to be carbon neutral by 2012 may cost the taxpayer millions of pounds in carbon offsetting per year.

- While the largest contribution to government's overall reported carbon emissions comes from buildings (Figure 3), emissions from travel (including road-based travel) are a significant proportion of the total. For more information on travel, please see the Trovel thematic area analysis.
Figure 3 Reported carbon sources from the SDiG process 2007/08 (tonnes of carbon)

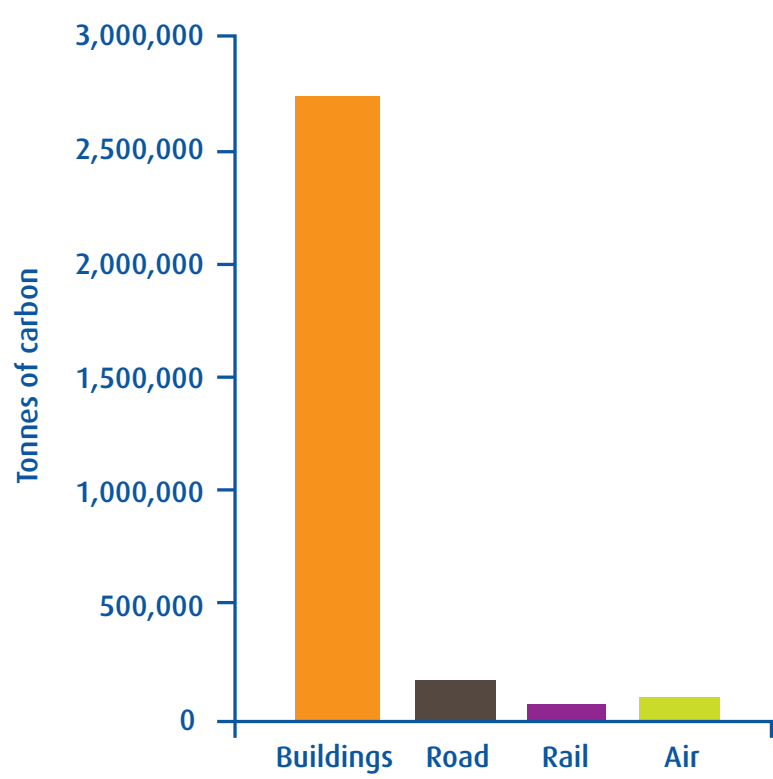

Carbon source 


\begin{tabular}{|c|l|l|l|l|}
\hline & $\begin{array}{l}\text { Size of } \\
\text { investment }(£ M)\end{array}$ & $\begin{array}{l}\text { Power generated } \\
\text { in } \mathrm{MW}\end{array}$ & $\begin{array}{l}\text { Annual yield } \\
\text { in GWh }\end{array}$ & $\begin{array}{l}\text { Annual } \mathrm{CO}_{2} \text { savings } \\
\text { (tonnes of } \mathrm{CO}_{2} \text { ) }\end{array}$ \\
\hline Wind Turbine & $£ 2,659$ & 1,300 & 2,887 & $1,639,735$ \\
\hline Small 50 kW & $£ 1,120$ & 403 & 530 & 300,780 \\
\hline Medium 100 kW & $£ 692$ & 299 & 786 & 446,318 \\
\hline Large 100 kW & $£ 847$ & 598 & 1,572 & 892,637 \\
\hline Photovoltaic & $£ 1,125$ & 330 & 280,500 & 159,324 \\
\hline Total & $\mathfrak{£ 3 , 7 8 4}$ & $\mathbf{1 , 6 3 0}$ & $\mathbf{2 8 3 , 3 8 7}$ & $\mathbf{1 , 7 9 9 , 0 5 9}$ \\
\hline
\end{tabular}

\section{Recommendations}

- Government and all its departments, agencies, NDPBs and other bodies need to produce carbon footprints to help them understand the carbon impacts of all their operations and procurement activities as the first step in understanding all of their impacts. This is key to the carbon reduction strategies which government needs in order to meet its internal target as well as its commitments under the Climate Change Act 2008.

- Government should also work to capture and quantify all types of impacts through the supply chain in all areas of its spend. An organisation's carbon impacts can be divided into boundaries based on three "scopes". ${ }^{13}$ Scopes 1 and 2 deal with direct and indirect emissions from energy use and fleet vehicles. "Scope 3 " of carbon footprints deals with the carbon impacts of outsourced and supply chain activities, embedded carbon in products as well as indirect travel emissions such as air and rail travel, taxi and hire cars.

- Continued energy efficiency initiatives must be a priority for government. While low cost energy efficiency improvements should be considered first, government should also develop a programme of support (advice and finance) for self-generated renewable energy on the government estate where reasonably practicable. In addition, government should actively promote the take up of the Salix fund - a rolling financing mechanism investing $£ 20 \mathrm{~m}$ in low carbon and energy efficiency technologies. ${ }^{14}$ Only one department
(Defra) has applied for Salix funding to date. This should include regional or collaborative schemes to allow departments to work together and share costs as well opportunities.

- The SDC has undertaken initial research exploring the potential for self-generated renewables on the government estate using wind energy and solar photovoltaics (PV) as examples of two appropriate technologies. The result of this study identifies the size of the investment required, the potential energy production, and the associated carbon savings for both technological types. ${ }^{15}$ Biomass was also considered, but insufficient information existed to draw any conclusions. Table 1 above gives the preliminary findings 


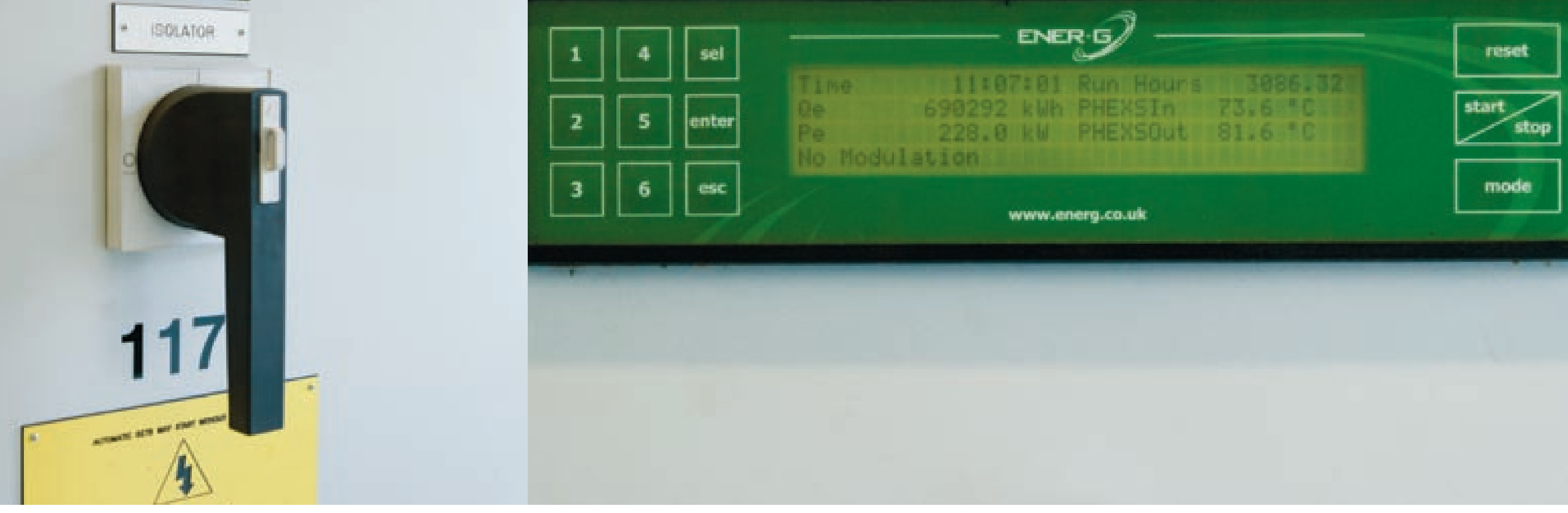

\section{Energy}

Energy is required to light, cool and heat office buildings and power IT systems across the government estate. At present the majority of energy used by government is directly or indirectly produced using fossil fuels. Ensuring that energy is used efficiently has important environmental, economic and social benefits.

The use of fossil fuels and electricity is a key contributor to UK greenhouse gas emissions and climate change. In addition, these types of fuel are finite and the UK is heavily reliant on foreign suppliers. This means that the security of energy supply is likely to become less reliable in the coming years, which will have a significant impact upon future generations.

Government is currently assessed against three energy-related areas: energy efficiency per square metre $\left(\mathrm{m}^{2}\right)$, the percentage of electricity sourced from renewables and the percentage of electricity sourced from Combined Heat and Power (CHP). Using electricity from renewable sources and CHP helps government to achieve its sustainability goals. Procuring electricity from renewable sources sends a strong signal to the market, and CHP is a more efficient process of converting energy and reducing carbon emissions than can be obtained from traditional electricity sources. The current CHP target is not applicable for a department if more than $85 \%$ of electricity is sourced from renewables.

\section{Performance against targets}

\section{Energy efficiency target}

Departments to increase their energy efficiency per $\mathrm{m}^{2}$ by $15 \%$ by 2010 , relative to $1999 / 00$ levels

- Government reported a $7.2 \%$ improvement in energy efficiency per $\mathrm{m}^{2}$ from the baseline year

- Although this represents some progress, performance is down from 2006/07, when excellent progress was reported (an improvement of $21.7 \%$ in energy efficiency per $\mathrm{m}^{2}$ from the baseline year). 
Figure 4 Comparison of energy sourced from fossil fuels and electricity between the baseline year and 2007/08 $\left(\mathrm{kWh} / \mathrm{m}^{2}\right)$

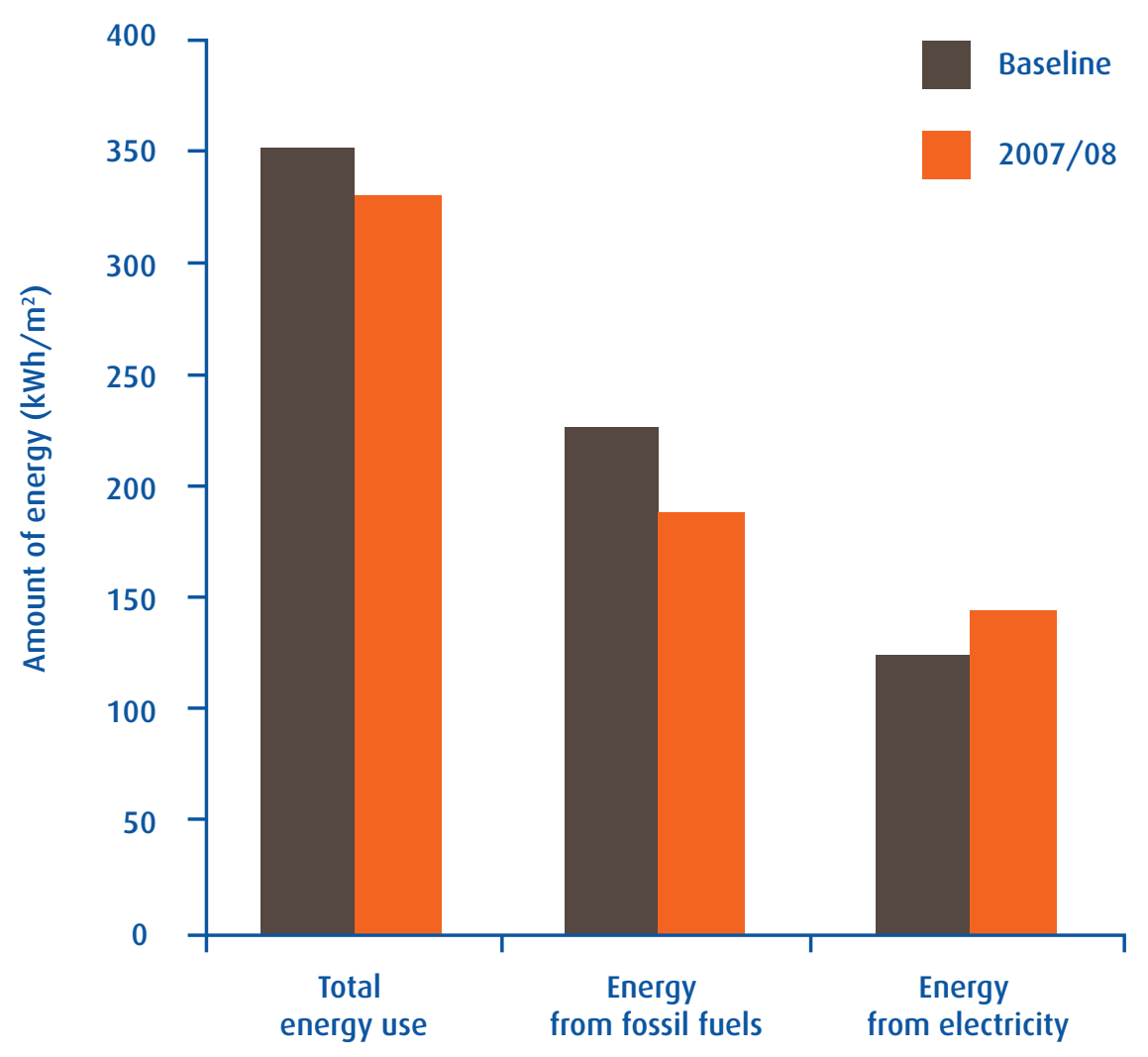

Fuel source
Figure 5 Total percentage of electricity derived from renewable sources and combined heat and power (CHP)

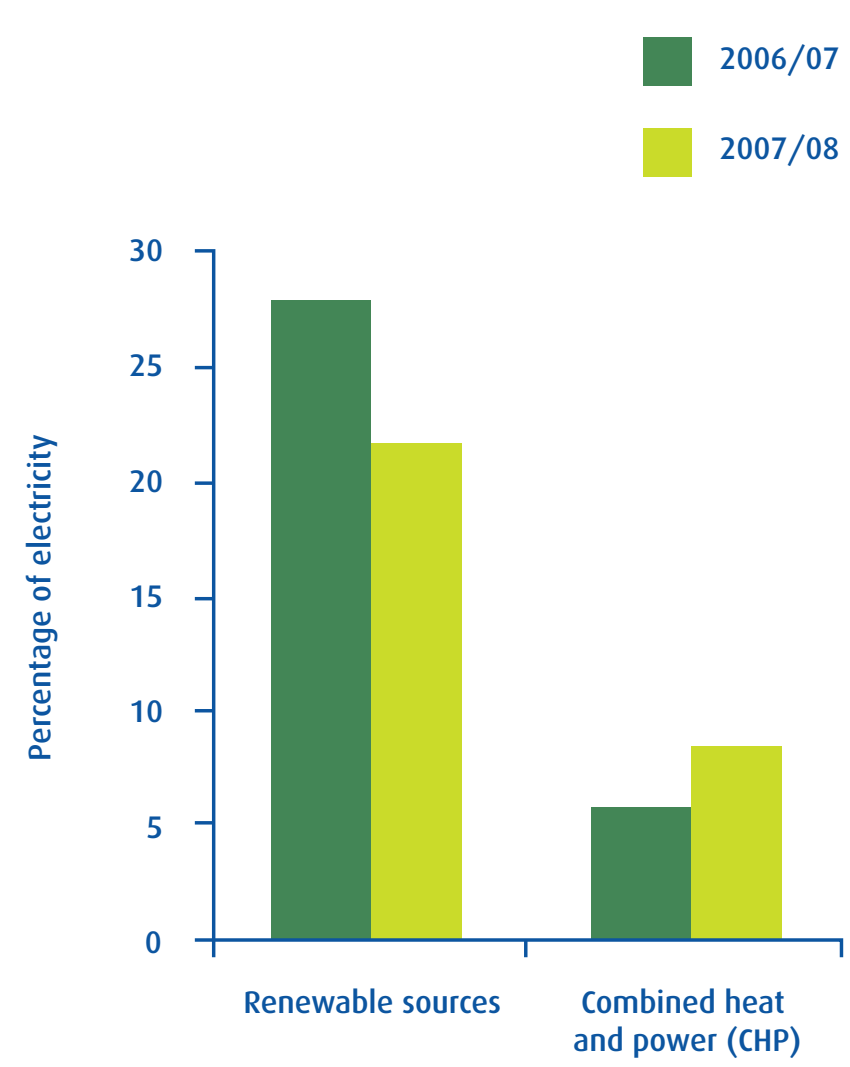

Electricity source 


\section{Issues}

- Government electricity usage is on the rise since the baseline. One of the key drivers may be the proliferation of computers, printers, laptops, chargers, lobby televisions, mobile phones and other Information and Communications Technology (ICT) and associated impacts e.g. air conditioning of server rooms as well as severe levels of waste due to the disposal of old ICT (including toxic materials). Government must address the root causes of both the energy consumption rise and its increasing waste, to encourage industry to improve ICT equipment life span, eco-design and energy consumption. ${ }^{18}$

- Sustainability in government buildings in terms of design and operations is poor. Pan-government figures continue to show poor performance against the BREEAM commitment, which ensures certain sustainable standards in the design of buildings. Only $42 \%$ of total projects (new build and major refurbishments) have achieved the required standard. For some departments this may be because BREEAM does not account for their unique operations (e.g. rural based sites). In terms of operational performance, as of January 2009 all public sector buildings with a total floor area of over $1000 \mathrm{~m}^{2}$ are required to have a Display Energy Certificate (DEC) showing the energy usage of a building and its operational rating from A to $G, A$ being the best and $G$ the worst. ${ }^{19}$ At the end of October 2008 only $49.5 \%$ of the buildings which are required to have a DEC actually did, with $59 \%$ of these buildings

\section{Figure 6 Percentage of government buildings at each Display Energy Certificate (DEC) rating}

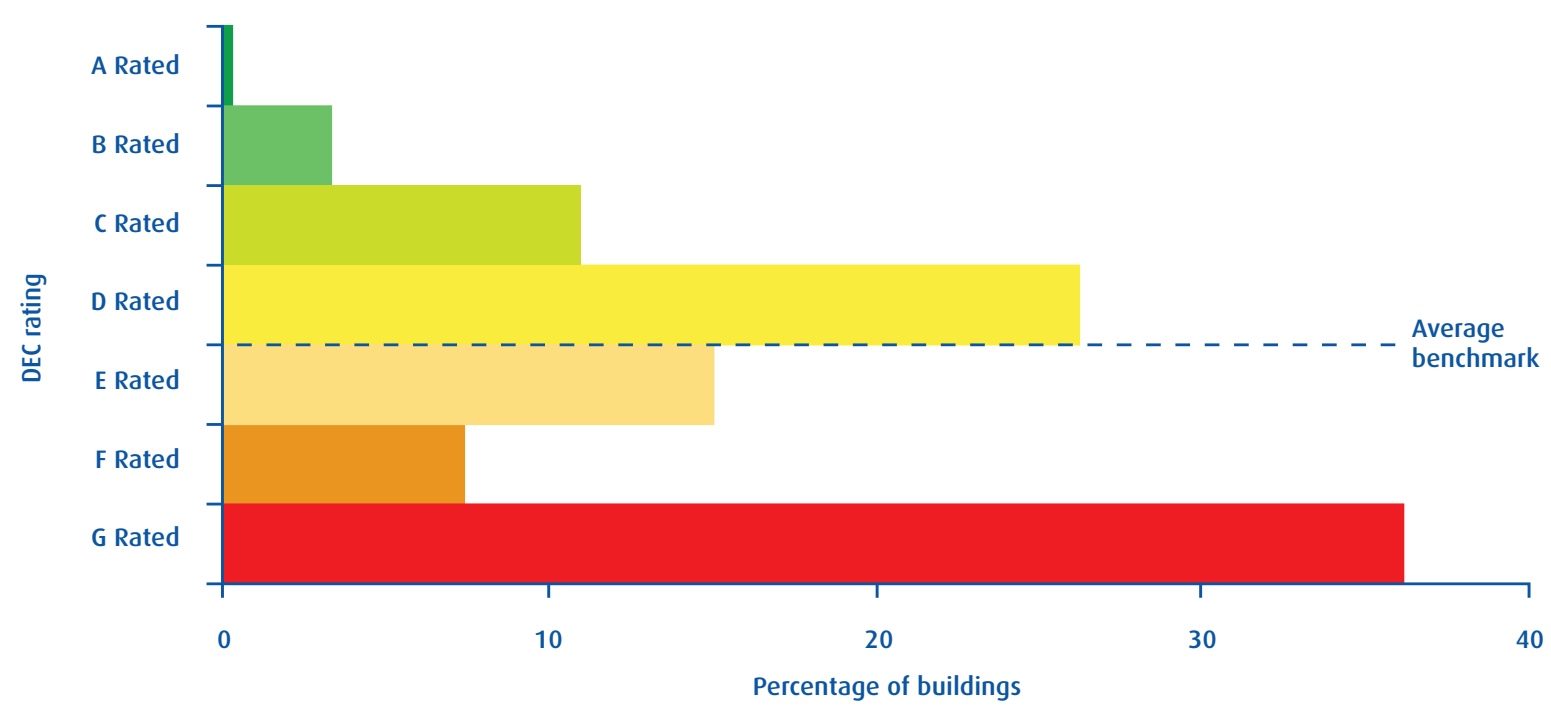

achieving a rating below the average benchmark (see Figure 6). Climate change adaptation, in addition to mitigation, is vital. As the climate changes, the demands on the estate infrastructure and energy consumption will increase; government must consider how it will respond to erratic weather changes and long-term temperature rises to maintain comfortable working conditions for employees.

- In the previous operational target framework, the target for CHP included the specification that energy sources from CHP must be of Good Quality. ${ }^{20}$ The current CHP SOGE target was carried forward from the previous framework; however, the stipulation for Good Quality CHP was lost when the SOGE targets were agreed. The total CHP generated electricity consumed on the government estate in 2007/08 was 311 gigawatt hours; however only 19 gigawatt hours come from Good Quality CHP (GQCHP). Therefore only $6 \%$ of the total CHP electricity consumed on the government estate in 2007/08 comes from good quality sources.

- Increasing energy efficiency is also about changing people's behaviour to reduce their energy consumption. If public sector workers are encouraged to consider the impacts of their energy use, this could have far-reaching effects across households and communities. 


\section{Recommendations}

- Whilst the existing Greening Government ICT Strategy (launched July 2008) represents an encouraging step towards making ICT usage more sustainable, government must consider urgently raising the ambition level of the Strategy as industry awareness and action has gathered around this agenda. The Chief Information Officers and Chief Technology officers have responded well to the first set of targets but they must now be increased. The Strategy itself acknowledges there is a need to work with departments and industry to explore and invest in radical green ICT solutions, ${ }^{21}$ but also to consider issues relating to life cycle impact and disposal of old IT hardware. Some solutions could include initiatives such as:

- Extended procurement cycles to a mandatory minimum of four years. Equipment replacement must be carefully evaluated and not judged on electricity usage alone but rather the wider $\mathrm{CO}_{2}$ output of the production, manufacturing and full lifecycle of the equipment as stated in the Strategy

- Reduce duplication of equipment per person. For example, cease allowing two computers per staff member

- Government and outsourced data centres must adhere to the basic principles included in the European Data Centre Code of Conduct to ensure server optimisation, the removal of over-duplication of data, as well as sharing data centres and using appropriate levels of ambient room temperatures in server rooms
- Ensure procurement of equipment at the highest international standards as well as working with supply chains to reduce unnecessary packaging.

- Departments must continue to improve the standards of buildings to achieve greater energy efficiency (e.g. zero carbon new public sector buildings by 2018 as announced in Budget 08). This means achieving post-construction certificates for operations as well as meeting BREEAM (or more appropriate) standards for design and ensuring DEC ratings are improved by one rating annually, particularly those below the average benchmark. Departments must also ensure that consideration of the changing climate is taken into account in clearly defined sustainability appraisals applied to all new builds, major refurbishments, re-locations and estate rationalisation.

- Government must ensure that any new CHP plants brought online are of Good Quality standard, must update existing CHP plants to the Good Quality standard where reasonably practicable, and must register with the $\mathrm{CHP}$ Quality Assurance (CHPQA programme).

\section{Case Studies}

Department for Children, Schools and Families (DCSF)

\section{Flexible Workspace Project}

The DCSF Flexible Workspace Project was a refurbishment instigated to reduce DCSF's carbon footprint while helping to create more efficient and flexible office space and working practices within the building. For further details see Annex B.

Department of Environment, Food and Rural Affairs (Defra)

\section{Lion House Alnwick}

Lion House in Alnwick, Northumberland is a multi-award winning flagship ultra low-emissions development which is designed to achieve exemplary standards of sustainability and environmental performance. It achieved the highest BREEAM score in the UK in 2008 and an A+ Energy Performance Asset Rating (scoring minus 14, the highest possible achievement and the first of its kind on the government estate). For further details see Annex B. 


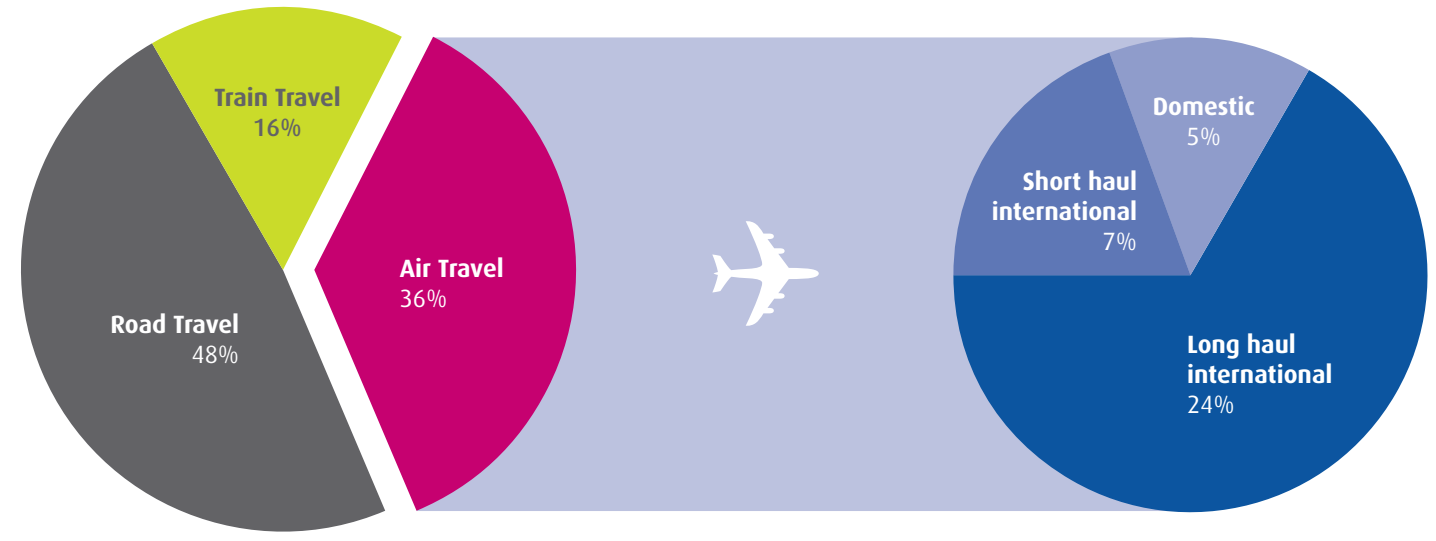

\section{What is driving travel performance?}

- Ten departments have adjusted baseline data due to Machinery of Government Changes to include new or better data. In these cases, improvements will be down to better data quality rather than improved performance. For further details on rebaselining, see Chapter 4.

- While performance overall seems to have improved since 2006/07, the primary driver behind this is that the data collected by departments for the $2007 / 08$ period is far more accurate. Future comparisons with 2008/09 data will show more clearly whether government performance against this target is improving.

\section{Issues}

- The amount and accuracy of data relating to different modes of transport is variable. Rail travel data can be difficult to collect due to poor management information systems, while air travel data is often collected by travel providers to a high quality. However, analysis quality issues, particularly in the application of the carbon conversion factors by some

- The UK targets to reduce carbon emissions now include aviation. As air travel accounts for $36 \%$ of government's total travel (Figure 7), and with long-haul flights making up the majority of this, this needs to be reflected in government's own framework to reduce emissions from all types of air travel. of the road travel data still shows serious data departmental practitioners.
For some departments with clear international remits, the percentage of travel carbon emissions is understandably high (DFID 98\%, FCO - 98\% and ECGD - 76\%). But other departments without such remits still show a much greater percentage than the pangovernment average (CO - $87 \%$ and FSA $77 \%)$.

- Domestic air travel is often cheaper than domestic rail travel. Managers within government, operating to their allocated budgets, will naturally seek to get the most from those budgets and may therefore be inclined to choose the cheapest option for travel.

- Mileage can be claimed at rates above fuel costs to account for wear and tear. However, this difference incentivises civil servants to drive their own cars for work.

- There is a lack of government guidance to induce behaviour change and ensure individuals and departments take the most sustainable travel options.

- The government's fleet consists mainly of small/medium diesel vehicles (Figure 8). Despite a target for new vehicle procurement of $130 \mathrm{gCO}_{2} / \mathrm{km}$, there is a lack of clear commitment to procure ultra-low carbon vehicles, as well as a lack of guidance to induce behaviour change to ensure the most sustainable travel options are taken. 


\section{Recommendations}

- Government must produce a clear pangovernment travel strategy which provides mandates, guidance and information to departments to enable them to make sustainable travel decisions, including reducing the need to travel. A part of this strategy should be for a significant programme of investment in and encouragement of ICT solutions (such as videoconferencing), as well as providing guidance to the other types of support available, such as the Energy Saving Trust's green fleet programme..$^{22}$ The SDC is currently working in partnership with the Centre of Expertise in Sustainable Procurement (CESP) on a review of sustainable travel for the public sector and will make recommendations for future work.

- Government should implement controls restricting domestic/GB air travel, as well as flights to Paris and Brussels. These shorter flights should be avoided in the first instance using alternative forms of communication; however where this is not possible they should be taken using more sustainable methods of travel such as rail. As shown in Figure 7, this will reduce carbon emissions from domestic flights by up to $5 \%$.

- Current travel strategies provide a perverse financial incentive for vehicle travel by allowing staff to claim mileage at rates above fuel costs. Instead, government should incentivise staff to use more sustainable
Figure 8 Distribution of car engine sizes and fuel types across the government fleet 2007/08

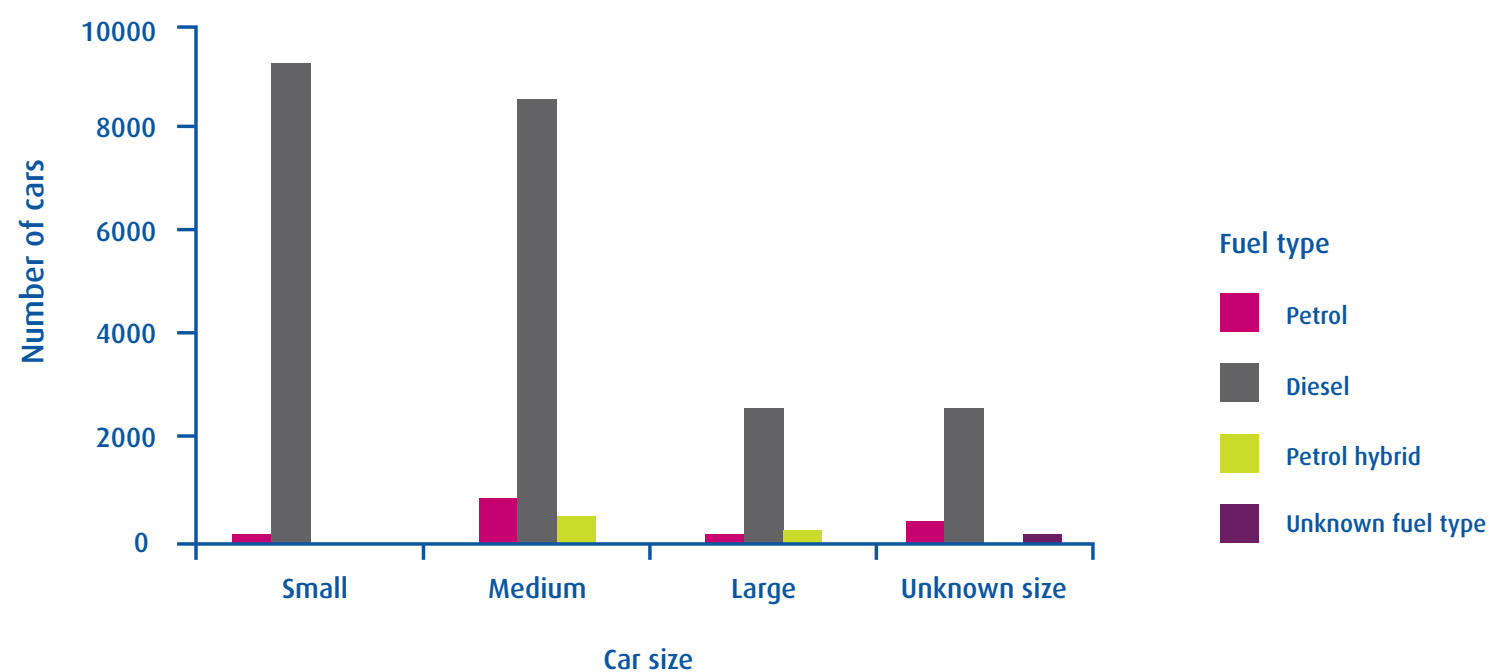

methods of travel, or avoid traveling by working from home. For example, a programme to partially reimburse home workers for household fuel bills would cut down on required office space, reduce workplace fuel bills and reduce commuter congestion.

- The Low Carbon Vehicle Procurement Programme (LCVPP) represents a commitment by government to be a leader in the procurement of lower carbon vehicles, which the SDC welcomes. However, as the programme focuses on vans in the first phase $(£ 20 \mathrm{~m})$, government must broaden the commitment to include all sizes and types of ultra-low carbon vehicles, including electric vehicles powered by renewable energy sources. The SDC recommends an announcement of a significantly larger fund in the future to replace government fleet vehicles with ultra-low carbon vehicles which would help government meet its carbon reduction commitments, as well as stimulating innovation in the industry. To achieve real results in this area, government should consider an investment of $£ 250 \mathrm{~m}^{23}$ in addition to the $£ 30 \mathrm{~m}$ earmarked for a subsequent phase of LCVPP. 
Figure 9 Percentage of total waste arisings by department reported for $2007 / 08$

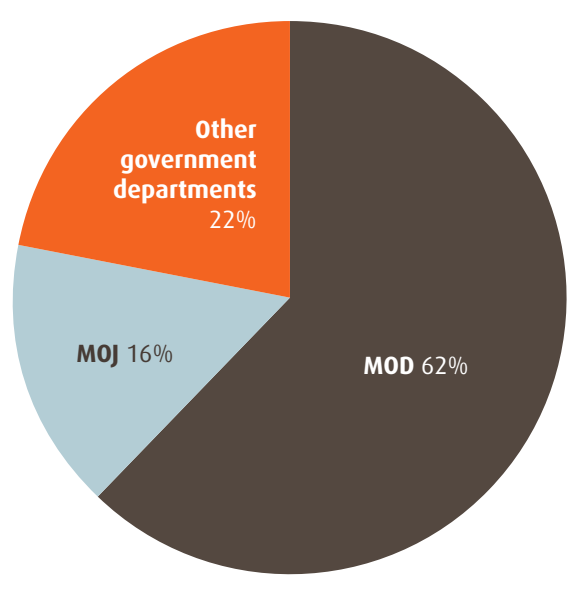

\section{Recycling target}

Departments to increase their recycling figures to $40 \%$ of their waste arisings by 2010

\section{- Pan-government performance reported} $35.0 \%$ recycling of their waste arisings

- Whilst this is still on track for the target, and most departments either held their performance rating or improved, this represents an overall decrease from 2006/07 when $38.5 \%$ recycling was reported.

Figure 10 Pan government

changes in levels of

waste arisings and

recycling (tonnes)

from the baseline year

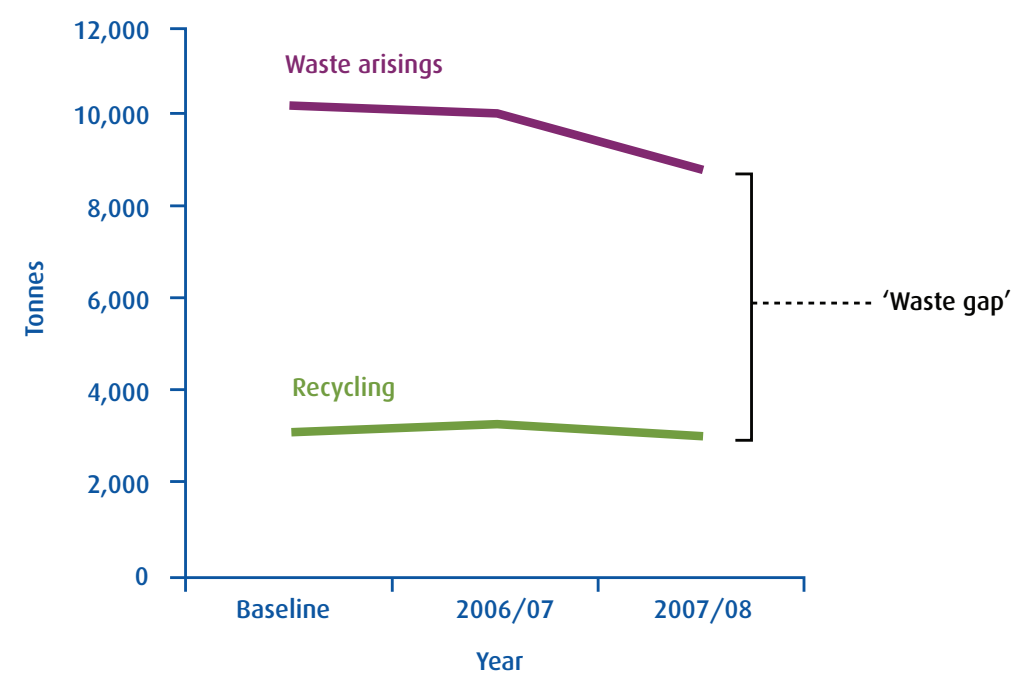

What is driving waste and recycling performance?

Waste

- The scope of coverage has improved over the 2007/08 period with eight departments reporting waste figures for the first time.

- MOD and MOJ have a significant skewing effect on pan-government performance (Figure 9). While MOJ's data has improved, the quality of MOD's data is currently poor due to the challenge they face in managing their estate, e.g. transient military population going on and returning from operations and training, and the management of waste through long term facility management contracts let before the need to provide waste data. Improvements in MOD's waste data quality next year will have a very significant influence on pan-government performance. As reported last year, MOD is removed from pan-government figures as it has no baseline data.

\section{Recycling}

- Improved data from MOJ has ensured that the government's good performance against the recycling target has continued for the year 2007/08.

- The ongoing improvement of waste management contracts and good work with facilities management professionals has also ensured performance remains on target this year.

- Despite being on track to meet this target, the pan-government recycling rate is down slightly from the 2006/07 reporting year; however this may in part be due to improved data quality. Next year's 2008/09 data will help show more clearly whether this is a one year anomaly or a continuing trend. 


\section{Issues}

- The way in which we dispose of the resources and products we use has an enormous impact on the environment. Effective and responsible demand management is vital in reducing these impacts.

- A high level of waste production and its associated impacts is not solved solely by greater levels of recycling. Reduction in the amount of waste produced should be the primary concern. There is a current 'waste gap' (Figure 10) between the high levels of waste produced and more moderate levels of recycling. Ultimately as waste production

\section{Recommendations}

- Government must advocate the use of sustainable procurement practices to better control the input of consumable materials into departmental operations, in addition to the positive contractual changes already made to manage the outflow of waste materials. Recycling is not the solution to the waste problem.

- While the primary emphasis must be on reducing the amount of waste produced in accordance with the waste hierarchy, infrastructure to recycle is available and government has a responsibility to set and enforce contracts which make use of this infrastructure to its full capacity. falls and waste recovery (e.g. external re-use, recycling, composting and energy from waste) increases, the two lines of this graph should converge, thereby closing the 'waste gap'.

- Waste contracts and recycling services are not being used to their full capacity. Opportunities for collaborative procurement across government to share these contracts and services, where it would be beneficial, have not been fully recognised.

- Waste to landfill does feature in an organisation's carbon footprint and so

- Where waste volumes are low and costs are high, the use of inter-organisational waste contracts should be explored to achieve economies of scale. For example, larger volume waste streams could be undertaken on a more regional basis which allow for more cost effective and innovative waste and recycling solutions.

- Any major public sector capital expenditure projects should seek to aggressively reduce waste arisings throughout product life cycles, as well as sharing knowledge of these processes within government, and with the private sector. reducing the amount of waste sent to landfill can reduce an organisation's carbon footprint.

- The Landfill Tax rate for $2007 / 08$ was $£ 24$ per tonne and will increase by $£ 8$ per year until 1st April 2010. The escalation of this tax discourages the disposal of waste to landfill making recycling more cost effective. This would mean that at 2007/08 levels, the amount of waste after waste recovery $(289,242$ tonnes), if it is sent to landfill, would cost government $£ 6,941,815$ in 2008/09 and rise to $£ 11,569,691$ in $2010 / 11$.

\section{Case Studies}

Department for Work and Pensions (DWP) Swap Shop

The Sustainable Development Team within DWP developed the intranet based Swap Shop site to minimise waste and impact on budgets by ensuring that surplus or unwanted goods were redistributed around the DWP businesses. For further details see Annex B. 
Water use in new builds and major refurbishments target

Reduce water consumption to an average of $3 \mathrm{~m}^{3}$ per person/year for all new office builds or major office refurbishments

- Government reported average water consumption in new builds and major refurbishments as $10.6 \mathrm{~m}^{3}$

- This is poor performance against the target and must be improved upon for next year.

\section{What is driving water performance?}

- The MOD contributes the vast majority of the saving $\left(7.6\right.$ million $\mathrm{m}^{3}$ of the 8.6 million $\mathrm{m}^{3}$ saved), predominantly due to the leakage reduction work undertaken through the Project Aquatrine PFI (Private Finance Initiative) where private companies have taken on water and waste water services.

- There have been significant changes in the scope and the quality of the data reported e.g. data was provided by the Royal Mint as part of the HMT departmental family, and MOD provided an improved estimation of water consumption.

- While greater coverage is good practice, the inclusion of non-office operational activities can have a large skewing effect on the

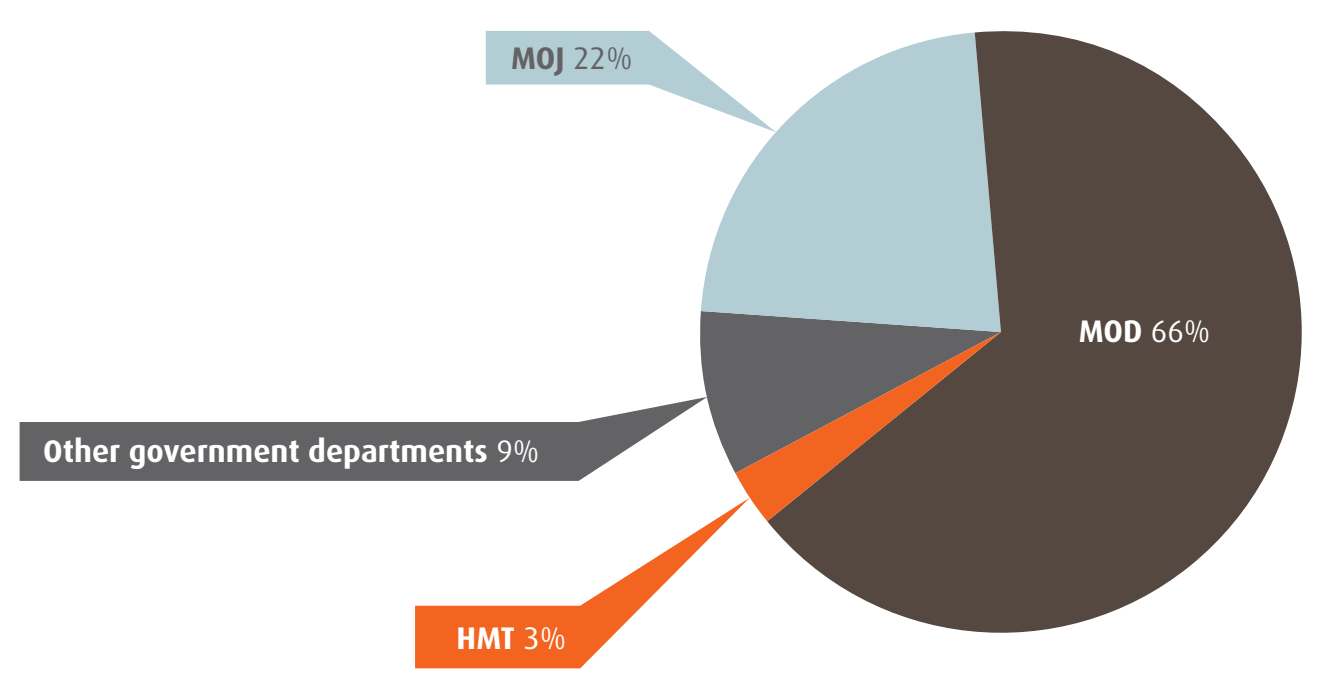

water consumption of some departments. For example, HMT and DCMS include Royal Mint and Royal Parks respectively, both of which use a large amount of water in their operations. Therefore, both DCMS and HMT show much higher water consumption figures per full-time equivalent (FTE) than the pangovernment average (Figure 12). For example, MOD provided improved data which included its on-site leakage. Other comparisons are made difficult by the uniqueness of different departments' operations. Much of the MOD's water is used for non-people related activities, e.g. washing aircraft, vehicles or tanks.

- Eight departments rebaselined their water consumption figures this year including MOD and $\mathrm{MO}$ ), the two highest water users whose progress against this target has helped improve pan-government performance through better quality data.

- The increased prevalence of water metering alongside the implementation and application of environmental management systems (EMS) is helping to encourage government water users to monitor and manage water efficiency.

- Departmental performance against the new build/refurbishment target suggests that opportunities for increased water efficiency, as a result of the inclusion of new efficient devices in new builds and refurbishment projects, has not yet been realised. 
Figure 12 Total water consumption $\left(\mathbf{m}^{3}\right)$ from office and non-office locations for $2007 / 08$ per FTE

" HMT figure includes Royal Mint and National Savings \& Investments.

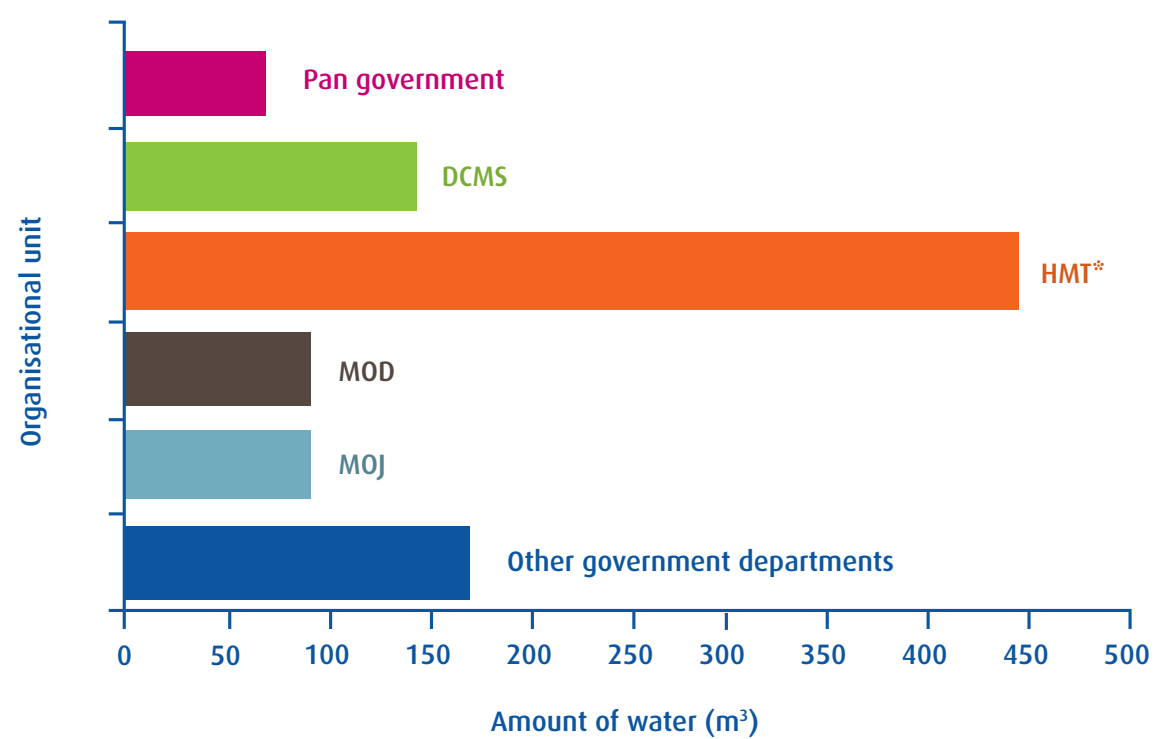

\section{Issues}

- The water footprint of the central government estate is largely unknown. An understanding of this is essential in considering the wider impacts of government's operational and procurement activity on water use.

- Water use may be affected by other initiatives intended to drive forward the sustainability agenda, such as the installation of showers to encourage staff to cycle to work. The larger benefits of sustainable development should be considered holistically to ensure decisionmaking is balanced and identifies all possible impacts.
- Heating water is more energy intensive and therefore has a larger carbon footprint than the treatment and supply of water. ${ }^{24}$ While catering and cleaning services require hot water, the move to install showers for staff, as mentioned above, will further increase hot water consumption on the government's estate. This will have implications for energy consumption, which could potentially be mitigated by the introduction of solar therma water heating systems.

- Climate change is expected to increase pressure on the UK's water resources and alter public demand so that the reuse and capture of water, though rainwater harvesting and use of grey water systems for example, will become increasingly important. 


\section{Recommendations}

- Government and departments should begin to develop the methodologies to produce water footprints in order to help them understand the water consumption used through their operations and procurement practices, including embedded water in products. Normalising this information into per person figures, as well as installing water meters, will allow departments to benchmark performance and identify areas for improved water efficiency in order to reduce overall water consumption.
- To increase water efficiency across the estate, government should explore the possibility of setting up a spend-to-save scheme based on the Salix Fund energy efficiency scheme which uses a revolving public fund mechanism. The size of such a fund would be relatively small. Preliminary research indicates that a fund of around $£ 3 \mathrm{~m}$ for the public sector "water Salix" scheme could save roughly 20\% of annual water use and have a payback period of less than a year. ${ }^{25}$ Further research must be undertaken in order to make fully informed decisions.

\section{Case Studies}

Vehicle and Operator Services Agency (VOSA) Eco-goods vehicle testing station (GVTS)

The concept was to design and build a sustainable office block to accompany VOSA's new goods vehicle testing station (GVTS) which incorporates many features that reduce its environmental impact, including a rainwater-harvesting system (pictured right) which recycles rainwater, reducing the mains water consumption of the site and the burden on discharge processes. For further details see Annex B.

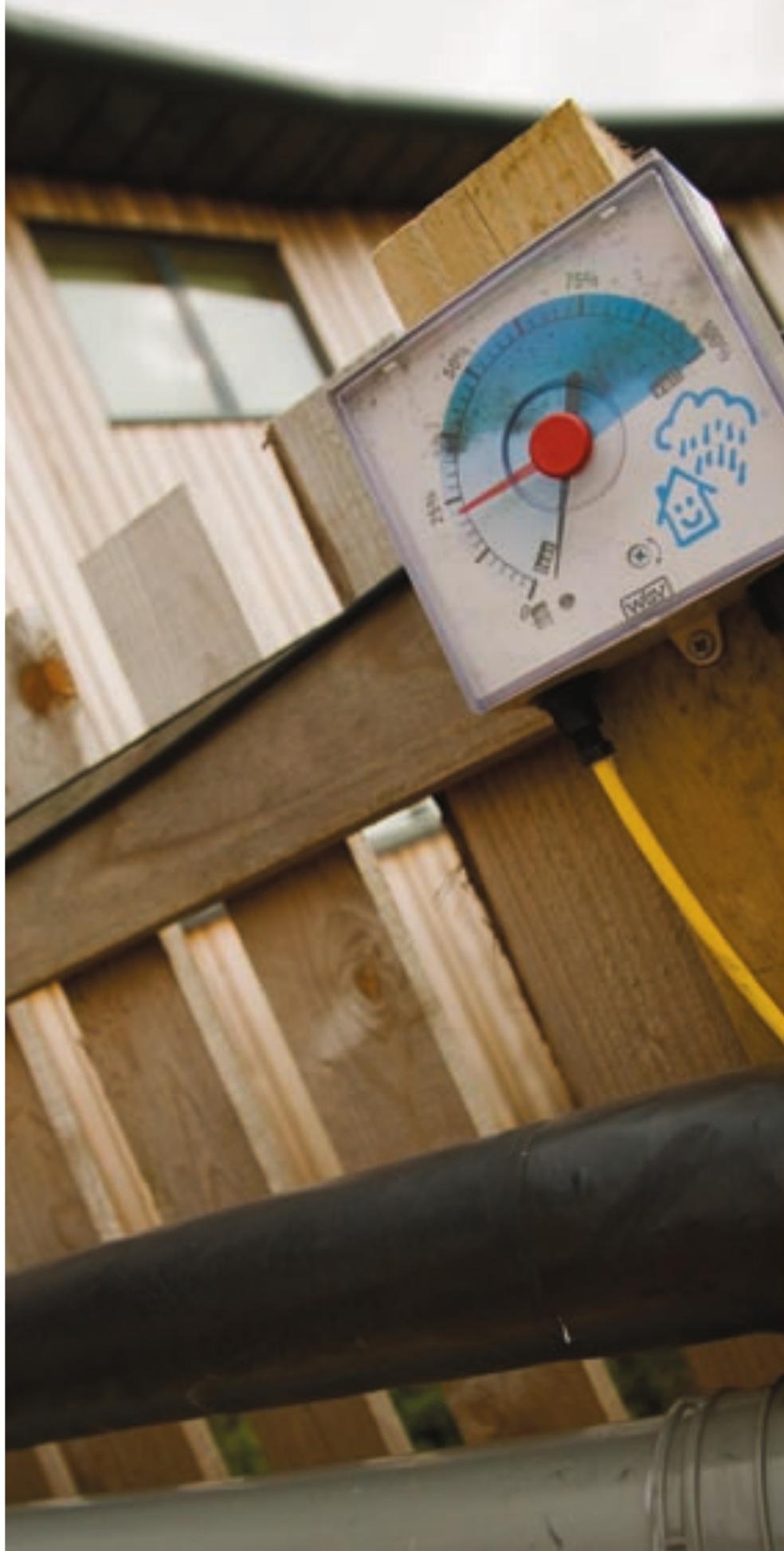




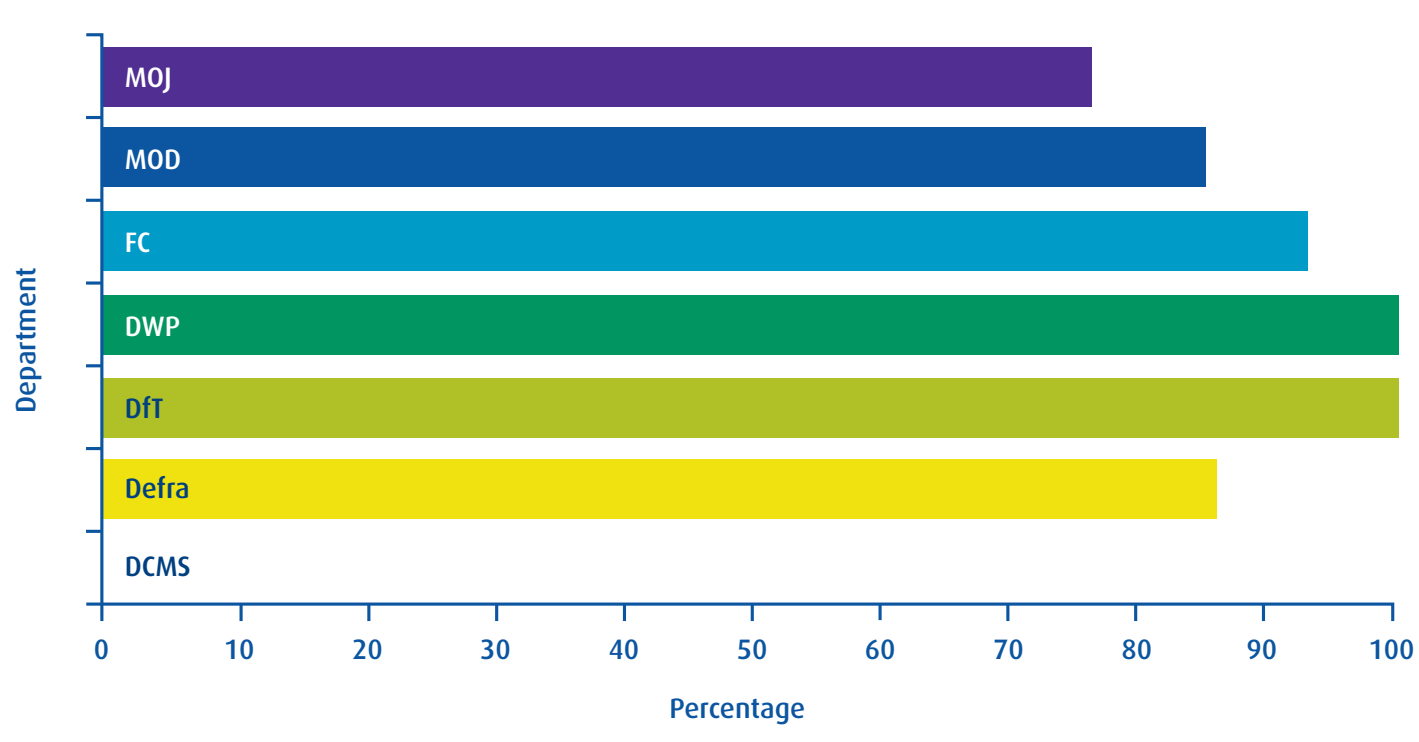

\section{What is driving biodiversity performance?}

- The target only directly affects seven departments who have SSSIs in their ownership or control (Figure 13).

- Performance has been strong since the target changed to those SSSIs under sole ownership from SSSIs with sole or partial ownership in 2006.

- DCMS's performance against this target is poor due to the limited scope of the assessment in which only one feature of the site is examined. According to DCMS all other features of its SSSI were in a 'favourable condition'.

\section{Issues}

- Biodiversity is about more than the management of SSSIs. As a large landholder government should be looking beyond this target to identify ways in which it can consider more comprehensively the diverse and dynamic nature of biodiversity throughout its estates and operations.

- Not all departments are biodiversity experts and so do not necessarily have the appropriate expertise to effectively manage and conserve the biodiversity of their estate.

- Favourable performance against this target depends on an annual assessment conducted by Natural England of one of the SSSI features designated as SSSI and included in SOGE targets

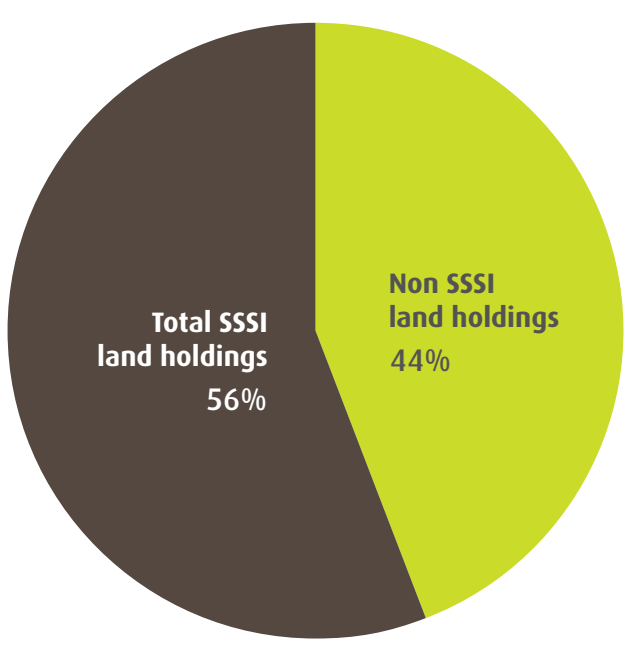

at one unit of the SSSI. The feature assessed at any one annual assessment may be different from the previous assessment, resulting in a

lack of continuity. This variation of assessment adds a layer of uncertainty as to whether government will achieve the target.

- Just over half of all land holdings are designated SSSIs and are therefore included in biodiversity targets (Figure 14). As the scope of the SOGE target is limited to SSSIs, a significant $44 \%$ of government's landholdings are not accounted for, limiting the potential for improving the quality of these landholdings and promoting biodiversity across the government's estate. 


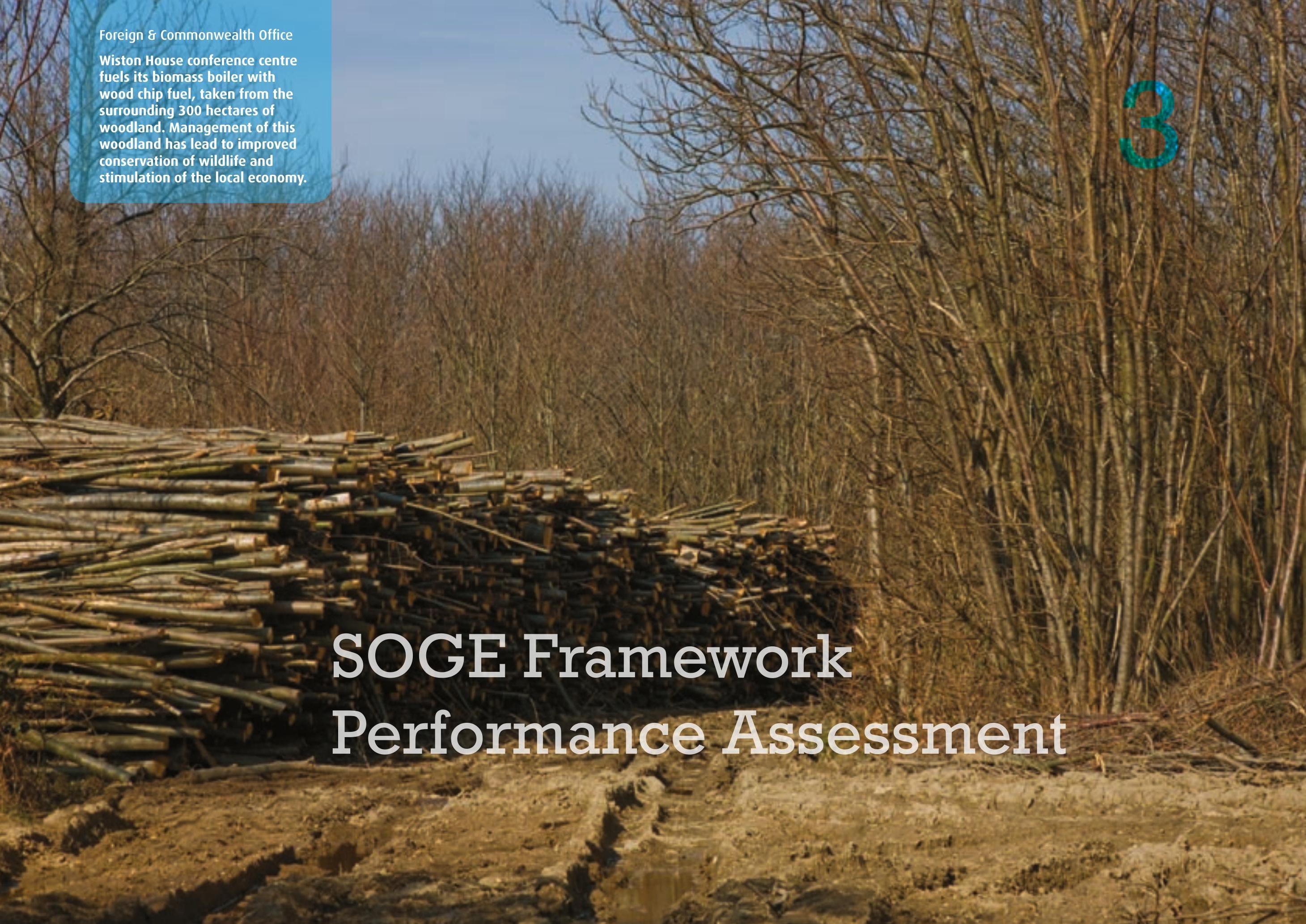

187 Foreign \& commonwealth office

fuels its biomass boiler with

\section{SOGE Framework}

Performance Assessment

mas: क 


\section{SOGE Targets}

\section{How is government performing overall against the Sustainable Operations on the Government Estate (SOGE) targets?}

Individual departments have a mixed record on achieving the SOGE targets. However, taken overall, it is clear that the government has made progress. Specifically:

- Government is "on track" or better in six of the ten SOGE target areas which have been assessed

- Carbon emissions from offices and the CHP target both show only "some progress" and so government is not sufficiently on track to meet these targets. However, encouragingly both targets show an improvement from last year's performance, with a $2.3 \%$ reduction in carbon emissions from offices and a 2.9\% increase against the CHP target since 2006/07

- "Some progress" was made against the energy efficiency per $\mathrm{m}^{2}$ target and "no progress" was made against the water consumption from new builds and major refurbishments target. However, there are fundamental issues with these targets and their corresponding metrics and therefore performance against either target can be misleading. For example, the energy efficiency target may be positive and the carbon reduction target negative if increased energy consumption is proportionally smaller than increased floor space. For the water target, major refurbishments over $£ 0.5 \mathrm{~m}$ are included in the target metric. However, as many of the refurbishments are purely decorative and have no impact on a building's plumbing, performance is misleading.

\section{Table 2 star rating scoring thresholds}

\begin{tabular}{|c|c|}
\hline $\begin{array}{l}\text { Performance star } \\
\text { rating }\end{array}$ & Definition \\
\hline 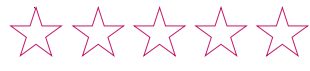 & Less than $25 \%$ of target points \\
\hline$\star \hat{\psi} \hat{r} \hat{r}$ & $25-39 \%$ of target points \\
\hline 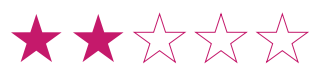 & $40-54 \%$ of target points \\
\hline 수추 & $55-69 \%$ of target points \\
\hline 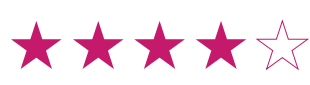 & $70-84 \%$ of target points \\
\hline 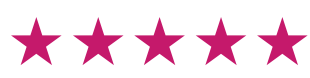 & $85 \%$ or more of the target points \\
\hline
\end{tabular}

\section{Table 3 Traffic light indicators for performance against the SOGE targets}

\begin{tabular}{|l|l|}
\hline $\begin{array}{l}\text { 'Excellent progress warranting recognition' which could mean a future target } \\
\text { performance level has already been achieved }\end{array}$ \\
\hline $\begin{array}{l}\text { 'Good progress' which is defined as being on track to hit the target } \\
\text { 'Some progress' which recognises that some progress has been made, but is } \\
\text { not sufficient to be on track to meet the target }\end{array}$ \\
\hline $\begin{array}{l}\text { 'No progress or poor progress' where no progress or, in our judgement, only } \\
\text { slight progress has been made. Red is also used where data was 'not known' }\end{array}$ \\
\hline Not applicable \\
\hline
\end{tabular}


Government has scored four out of five "stars" in the SDC's star rating system, one more than 2006/07 (see Table 4). ${ }^{26}$ The SDC welcomes this progress and recognises the hard work by practitioners in all departments and organisations covered by this process over the last few years.

Traffic light indicators are used to illustrate performance against the SOGE targets. Pangovernment performance against each target is illustrated in Table 5. The colours are based on the level of progress made using a RAG+ system (red, amber, green and blue) as set out in Table 3.
A 'direction of travel' indicator has been added to highlight whether performance has improved (an 'up' arrow) or worsened (a 'down' arrow) since 2006/07. For the full scoring methodology used for the SDiG assessment, see Annex C.
Table 4 Pan-government SOGE performance star rating

\begin{tabular}{|c|c|}
\hline \multicolumn{2}{|c|}{ Overall rating } \\
\hline & $78 \%$ \\
\hline $\begin{array}{c}\text { An improvement of } \\
1 \text { star compared to } \\
2006 / 07 .\end{array}$ & $\begin{array}{c}\text { An improvement of } \\
12.7 \% \text { compared to } \\
2006 / 07 .\end{array}$ \\
\hline
\end{tabular}

Table 5 Traffic light indicators of pan-government performance against the SOGE targets

\begin{tabular}{|c|c|c|c|c|c|c|c|c|c|}
\hline \multicolumn{3}{|c|}{ Climate Change and Energy } & \multicolumn{2}{|c|}{$\begin{array}{c}\text { Sustainable Consumption } \\
\text { and Production }\end{array}$} & \multicolumn{3}{|c|}{ Natural Resource Protection } & \multicolumn{2}{|c|}{$\begin{array}{c}\text { Renewable Energy } \\
\text { and CHP }\end{array}$} \\
\hline 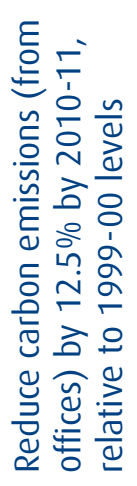 & 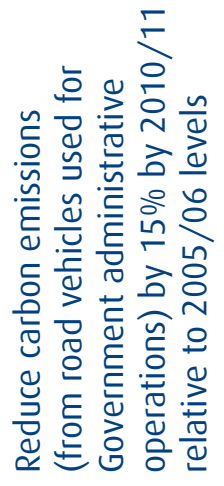 & 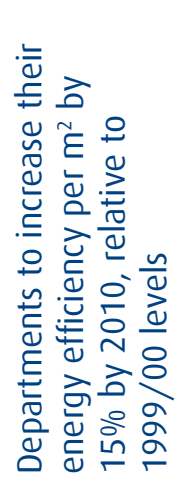 & 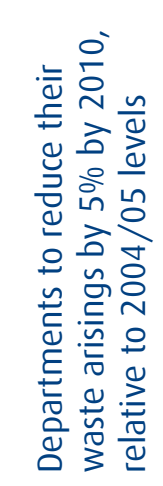 & 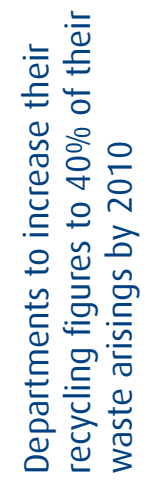 & 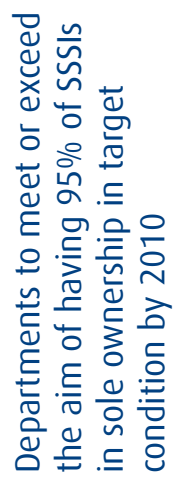 & 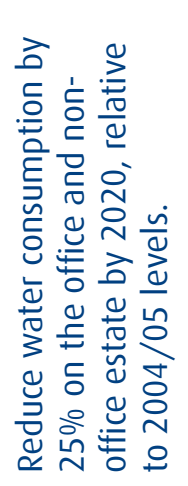 & 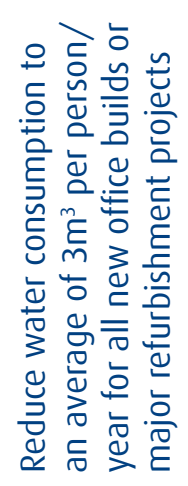 & 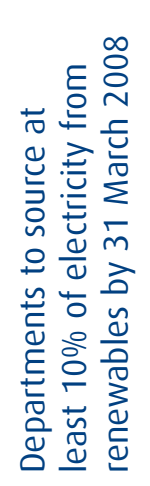 & 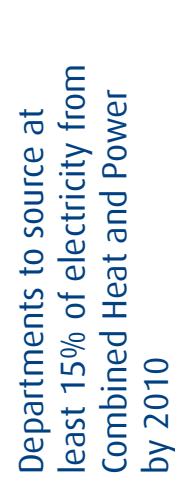 \\
\hline & & & & & & & & $\nabla$ & \\
\hline
\end{tabular}




\section{Mandated Mechanisms}

- A decrease of $6.3 \%$ in carbon emissions from offices since the baseline year. This is an improvement of $2.3 \%$ from 2006/07. However, government is still not on track to meet the $2010-11$ target of a $12.5 \%$ decrease, and rate of reduction still needs to be accelerated to meet the SOGE target.

- Good progress against the renewables target with $\mathbf{2 2} \%$ of electricity derived from renewable sources. However, government is performing less well than 2006/07 when $28.3 \%$ of electricity was derived from renewable sources.

- Some progress against the CHP target with a total of $8.7 \%$ of electricity derived from CHP, compared to 2006/07's 5.8\%. However, government is still not on track to source at least $15 \%$ of electricity from CHP by 2010 .

- Carbon emissions from road vehicles have improved dramatically this year since $2006 / 07$ with a reduction of $10.3 \%$ from the baseline. Performance has gone from an increase in carbon emissions against the baseline in 2006/07 (1.5\%) to making good progress in reductions this year.
- Performance against the waste target reported excellent progress with a $\mathbf{2 8 . 8} \%$ reduction in waste arisings since the baseline year, which already exceeds the $\mathbf{2 0 1 0}$ target. This is also a dramatic improvement since 2006/07 when a 5.3\% reduction in waste arisings since the baseline year was reported.

- Performance against the recycling target reported good progress with a recycling rate of $\mathbf{3 5 . 0} \%$. However this was a slight drop compared to 2006/07 (38.5\%).

- Biodiversity shows good progress against the target with $88 \%$ of SSSIs in target condition. Performance has improved from $82 \%$ of SSSIs in target condition in 2006/07, and this needs to be sustained to meet the $95 \%$ by 2010 target.

- Excellent performance has been made against the water consumption target, with a $\mathbf{1 7 . 8 \%}$ reduction in water consumption. This is a marked improvement from $2006 / 07$ 's $0.1 \%$ reduction against the baseline year.
Are departments using the tools and mechanisms in place to support performance improvement against the SOGE targets?

The extent to which government is implementing the tools and mechanisms to achieve sustainability goals is relatively poor. Specifically:

- Government is only "on track" (a green traffic light) to meet one of the five mandated mechanisms

- Of the rest of the mechanisms, government has made "no/poor progress" (a red traffic light) against two mechanisms and only "some progress" (an amber traffic light) against the remaining two.

Government has scored two out of five "stars" in the SDC's rating system. ${ }^{27}$ In order to continue improving performance against the SOGE targets government needs to work harder to ensure that these tools and initiatives are implemented across government. Due to slight changes in the scoring methodology, this rating is not comparable to last year.

Traffic light indicators are used to illustrate performance against the mandated mechanisms and the SPAP commitments, as shown in Table 8. The colours are based on the level of progress made using a RAG system (red, amber and green) as set out in Table 6. 
- Figures continue to show poor performance against the Building Research Establishment Environmental Assessment Method (BREEAM) commitment, with only $\mathbf{4 2} \%$ of total projects (new build and major refurbishments) achieving the required standard. However, this is up significantly from last year when only $8 \%$ of total projects achieved the required standard

- Implementation of Environmental Management Systems (EMS) has shown some progress towards full coverage across government with $\mathbf{5 4 . 7} \%$ of sites and $\mathbf{6 8 . 2} \%$ of staff covered. This still falls short of the $80 \%-100 \%$ coverage of staff and/or sites which would be considered good progress. However, this is a major improvement from last year when only $23.7 \%$ of sites and $26.5 \%$ of staff were covered

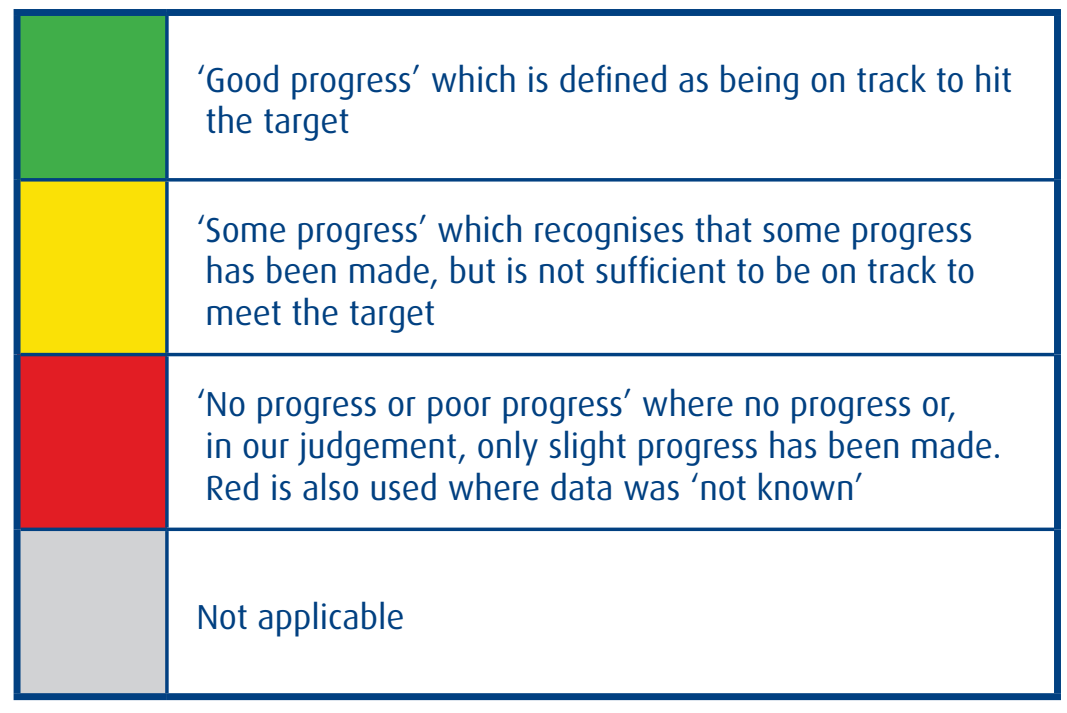

Table 7 Pan government mechanisms star rating

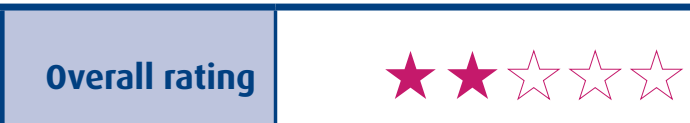

\section{Table 8 Traffic light indicators of pan-government performance against the Mandated Mechanisms}

\section{Application of BRE's}

Environmental Assessment

Method excellent standards or

equivalent, to all new builds

and major refurbishments

\section{Coverage of certified and}

non-certified Environmental

Management Systems (EMS)

\section{All departments to conduct} Sustainability Appraisals of

office relocations
Departments to adopt The Carbon Trust's Carbon Management Programme or Energy Efficiency Accreditation Scheme
Sustainable

Development

Commission (SDC)

review of 'operations'

element of SDAP 


\section{SPAP Commitments}

To what extent are departments meeting the commitments set out in Annex B of the Sustainable Procurement Action Plan (SPAP)?

The UK Government has enormous buying power. The way in which this money is spent should development objectives. As outlined in the SPAP, published in March 2007, government was set a target to become one of the EU leaders on sustainable procurement by 2009. However, government's compliance against the specific commitments laid support delivery of the government's sustainable out in the SPAP is mixed.

Specifically:

- "Good progress" (a green traffic light) has been made against three of the six commitments in the SPAP

- "No or poor progress" (a red traffic light) is evident against one commitment, while "some progress" (an amber traffic light) has been made against the remaining commitments.

\section{Table 9 Pan-government's performance star rating against the SPAP commitments}

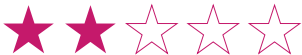

Government has scored two out of five "stars" in the SDC's star rating system (see Table 2 for the scoring thresholds). Government is not yet on track to meet all of the SPAP commitments and urgently needs to address these if it is to become an EU leader in sustainable procurement by the end of 2009. This rating was assessed for the first time this year.

Traffic light indicators are used to measure government's performance against achieving the commitments in the SPAP, as shown in Table 10. The colours are based on the level of progress made using a RAG system (red, amber and green) as set out in Table 6.

Table 10 Traffic light indicators of pan-government performance against the SPAP commitments

\begin{tabular}{|l|l|l|l|l|l|}
\hline $\begin{array}{l}\text { Permanent secretaries } \\
\text { have the SOGE targets } \\
\text { and SPAP commitments } \\
\text { incorporated into their } \\
\begin{array}{l}\text { personal performance } \\
\text { objectives }\end{array}\end{array}$ & $\begin{array}{l}\text { Staff with operations } \\
\text { and/or procurement } \\
\text { responsibilities have } \\
\text { the sustainable } \\
\text { operations targets } \\
\text { and/or SPAP } \\
\text { commitments } \\
\text { incorporated into their } \\
\text { personal performance } \\
\text { objectives }\end{array}$ & $\begin{array}{l}\text { SDAP delivering } \\
\text { procurement actions }\end{array}$ & $\begin{array}{l}\text { Including clauses for } \\
\text { Quick Wins/extended } \\
\text { mandatory product } \\
\text { standards (for all } \\
\text { relevant contracts - } \\
\text { new and existing) or } \\
\text { removing sub standard } \\
\text { contracts }\end{array}$ & $\begin{array}{l}\text { Engagement with } \\
\text { key suppliers } \\
\text { on sustainable } \\
\text { development, the } \\
\text { sustainable operations } \\
\text { targets and the SPAP } \\
\text { commitments }\end{array}$ & $\begin{array}{l}\text { Use of the Sustainable } \\
\text { Procurement Task Force } \\
\text { Flexible Framework }\end{array}$ \\
& & & & & \\
\hline
\end{tabular}


- All departments indicated that their Permanent Secretaries (or equivalent) have had the SOGE targets incorporated into their performance agreements, compared to 10 of 21 in 2006/07.

14 of the $\mathbf{2 1}$ departments included clauses for Quick Wins/extended mandatory product standards in all relevant contracts. This is up from 12 departments in 2006/07, but is still very disappointing.

- 19 of the $\mathbf{2 1}$ departments have reported using the Flexible Framework.

This is up from 17 out of 21 departments in 2006/07. 
The Goods Vehicle Testing Station in Bristol is an example of sustainable design and build.

During construction, waste was

reduced by $\mathbf{5 0} \%$ and recycling

increased by $20 \%$, compared with

conventional methods.

In use, the building saves $20 \%$ on

energy for heating and $50 \%$ on

water use for toilets.

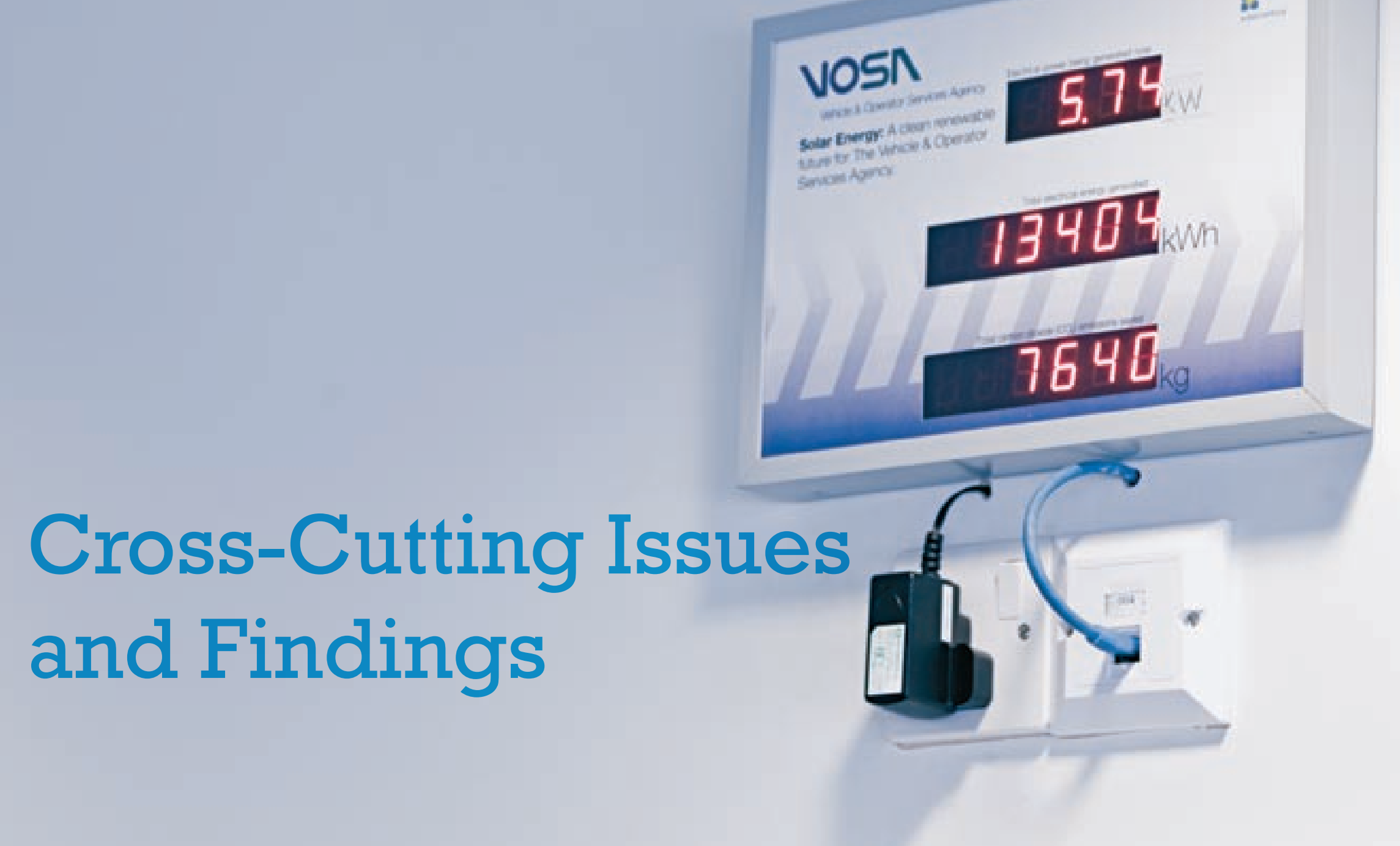




\section{Data Issues}

\section{- Data quality}

Data quality remains a concern, with many instances of errors and clarifications required to produce a final dataset. This emphasises the need for external verification of data before it is signed-off within departments. Government must also ensure that rigorous, centralised verification of the entire dataset is undertaken before sign-off.

\section{- Data collection}

For the past three years the SDC has gathered the performance data for SDiG as reported by departments through an online data collection platform. However, this has always remained government's data, not the SDC's. Last year the OGC and CESP worked with the SDC to use an

\section{Review of the SOGE Framework}

Government is currently undertaking a review of the SOGE Framework to improve its robustness. The SDC supports the review, as several of the targets government departments are required to meet have conflicting and not altogether comprehensive outcomes, or are no longer challenging enough. In particular:

- There is an issue with the way in which the energy efficiency target is measured, that is, energy use per $\mathrm{m}^{2}$. Progress against the energy efficiency target may be positive and progress against the carbon reduction target negative if increased energy consumption is proportionally smaller than increased floor existing central government property database, e-PIMS, to collect data. This year data collection is being fully transferred back to government for the period covering 2008/09 and will be collected centrally by CESP using a more advanced questionnaire via e-PIMS in future years. Not only will this reduce the reporting burden on departments by allowing data used for different purposes to be collected just once, this will also engender greater ownership and responsibility for the data which should in turn improve data quality. This will be extremely important as data quality remains an issue particularly on travel and waste. Government must focus on these areas.

space. The overriding aim for each department should be to reduce energy consumption and reduce carbon emissions. However, it is possible to increase energy consumption and still show a positive performance against the energy efficiency target.

- The waste and recycling targets are not ambitious enough. 0 n the whole, departments have shown that these targets are highly achievable and so applying more challenging targets will deliver greater benefits over time.

- The water consumption in the new build/ major refurbishments target is problematic

\section{- Historical data}

Machinery of Government changes and improved Environmental Management Systems (EMS) mean that historical data is often not of a high quality. The SDC oversaw a process for improving the quality of data through reviewing departmental baselines for the SOGE targets. The SDC produced guidance for departments detailing when "rebaselining" is appropriate, as well as chairing a panel (including CESP and Defra) to approve rebaselining cases. With over 40 cases approved, data quality has improved in many cases, but remains varied across departments and by theme. Government should ensure that for any future Machinery of Government changes, the process of rebaselining is undertaken.

because the value threshold for inclusion in the major refurbishment programme is $£ 0.5$ million and higher. In many cases this may include refurbishments which are purely decorative and so do not affect the water infrastructure of a building.

- The current biodiversity target concerns only SSSIs, and only specific features of these SSSIs. As SSSIs account for just over half of government's landholdings, a more comprehensive target is required to cover all of these landholdings in order to promote biodiversity across the government's estate. 
Vehicle and Operator Services Agency

Busy commuter routes, such as the Clifton Bridge shown here, were

eased by the move away from cars

and $1,579 \mathrm{~kg}$ of $\mathrm{CO}_{2}$ were saved.

\section{Anst}

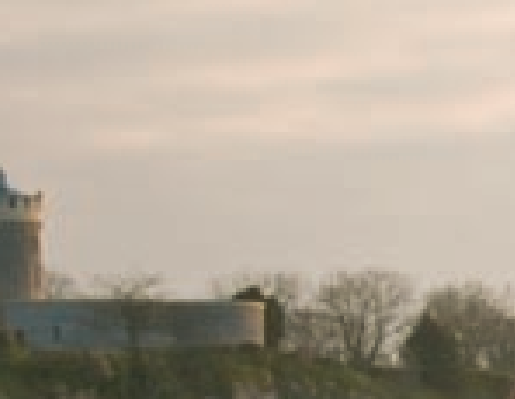

.
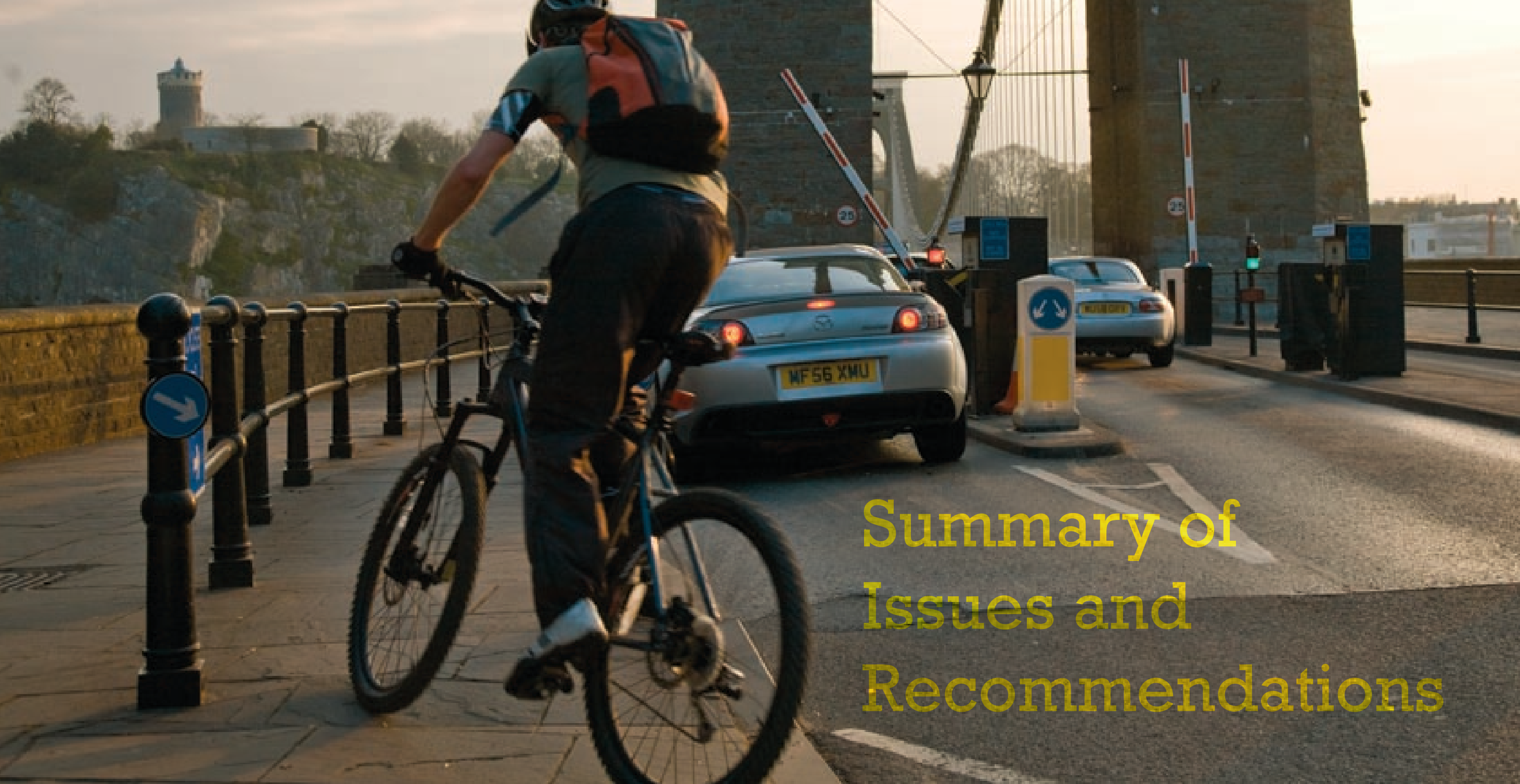


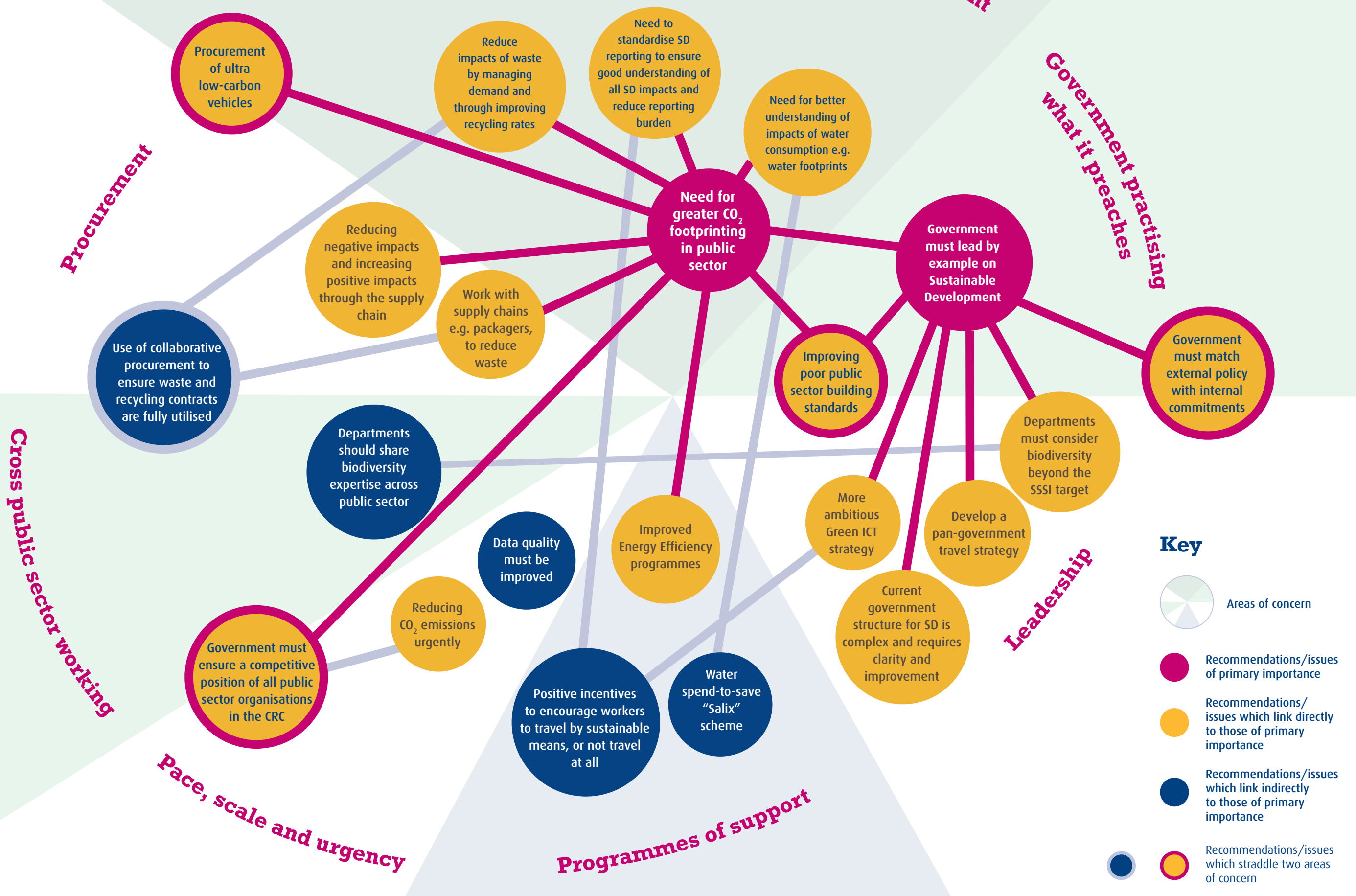


This section lists the issues and recommendations highlighted in Chapter 2 by each of the 6 thematic areas under examination.
The map opposite summarises the issues and recommendations from the SDiG 08 report against relevant areas of concerns. Linkages between the issues and recommendations show the interconnected nature of the sustainable operations and procurement agenda and serve to highlight the recommendations of primary concern. The map shows that there is an urgent need for government to understand all of its impacts, starting with its carbon footprint, if it is to fulfil its commitment of leading by example on sustainable development.

\begin{tabular}{|c|c|c|}
\hline Theme & Issue & Recommendation \\
\hline \multirow{5}{*}{ 동 } & \multicolumn{2}{|r|}{ Not enough progress reducing emissions } \\
\hline & $\begin{array}{l}\text { The government is not leading by example, or } \\
\text { contributing enough to UK wide emissions targetsi, } \\
\text { as it is not currently on track to meet its own carbon } \\
\text { emissions from offices target. }\end{array}$ & $\begin{array}{l}\text { Continued energy efficiency initiatives must be a priority for government. While low } \\
\text { cost energy efficiency improvements should be considered first, government should also } \\
\text { develop a programme of support (advice and finance) for self-generated renewable } \\
\text { energy on the government estate where reasonably practicable. Also, government } \\
\text { should actively promote the take up of the Salix fund - a rolling financing mechanism } \\
\text { investing £20m in low carbon and energy efficiency technologies.i" Only one department } \\
\text { (Department for Environment, Food and Rural Affairs) has applied for funding to date. } \\
\text { This should include regional or collaborative schemes to allow departments to work } \\
\text { together and share costs as well opportunities. }\end{array}$ \\
\hline & \multicolumn{2}{|c|}{ Carbon footprinting and supply chain/coverage } \\
\hline & \multirow[t]{2}{*}{$\begin{array}{l}\text { The full carbon impact of government's operations } \\
\text { and procurement, including the supply chain, } \\
\text { has not been quantified. Full and accurate carbon } \\
\text { footprinting is essential if emissions are to be } \\
\text { reduced and sustainability goals are to be achieved. }\end{array}$} & $\begin{array}{l}\text { Government and all its departments, agencies, NDPBs and other bodies need to produce } \\
\text { carbon footprints to help them understand the carbon impacts of all their operations and } \\
\text { procurement activities as the first step in understanding all of their impacts. This is key } \\
\text { to the carbon reduction strategies which government needs in order to meet its internal } \\
\text { target as well as its commitments under the Climate Change Act } 2008 \text {. }\end{array}$ \\
\hline & & $\begin{array}{l}\text { An organisation's carbon impacts are divided into boundaries based on three "scopes".iii } \\
\text { Scopes } 1 \text { and } 2 \text { deal with direct and indirect emissions from energy use and fleet vehicles. } \\
\text { "Scope } 3 \text { " of carbon footprints deals with the carbon impacts of outsourced and supply } \\
\text { chain activities, as well as indirect travel emissions such as air travel, taxis, and hire cars. }\end{array}$ \\
\hline
\end{tabular}

i The Climate Change Bill has committed the UK to reducing its carbon emissions by $80 \%$ by 2050 . Budget 2008 announced the government's ambition that new public sector non-domestic buildings would be zero carbon from 2018, and other new non-domestic buildings would be zero carbon from 2019

ii www.salixfinance.co.uk/the company.html

iii For further information on the scopes (or operational boundaries) of a carbon footprint, please see: www.ghgprotocol.org/files/ghg-protocol-revised.pdf 


\section{Renewable energy}

Government has reported that it produces 42,356 kWh of electricity and $832,131 \mathrm{kWh}$ of heat from self-generated renewable sources. The electricity is from photovoltaics (322 kWh) on the MOD Defence Estates, and wind power $(42,034 \mathrm{kWh})$ in three departments: DfT, MOJ and MOD (Defence Estates). The heat is from biomass at FCO $(378,560 \mathrm{kWh})$, and from solar water heating by the MOD Navy and Army $(453,571 \mathrm{kWh})$. This means that energy from selfgenerated renewables is just a tiny fraction of overall energy consumption; $<0.01 \%$. This does not include any energy from CHP.
The SDC has undertaken initial research exploring the potential for wind energy and solar photovoltaics (PV) as two appropriate technologies for the government estate. The result of this study identifies the size of the investment required, the potential energy production, and the associated carbon savings for both technological types. Biomass was also considered, but insufficient information existed to draw any conclusions. Table 1 gives the preliminary findings of our work, but further research must be undertaken in order to make fully informed decisions. In particular, there are likely significant carbon savings possible through small-scale heat installations (i.e. solar thermal, heat pumps, biomass heat and biogas heat). The carbon savings from the type of investment in self-generated renewables proposed in Table 1 would account for $68 \%$ of government's carbon emissions from offices in 2007/08. There would also be significant cost savings from energy bills once the payback periods are realised. Other benefits would include a boost to the green technology sector as well as the construction industry. The SDC is currently working with the Department of Energy and Climate Change and other government bodies to explore the barriers and solutions to the use of more sustainable energy in the public sector. 


\section{Carbon Reduction Commitment (CRC)}

As recommended in SDiG 07, Government has committed all departments to participate in the Carbon Reduction Commitment (CRC), a legally binding climate change and energy saving scheme in which organisations have to measure their carbon emissions and pledge reductions. They can trade - selling surplus reductions to others, or buying credits if they produce too much carbon. The scheme extends much further into the public sector as school, hospitals, prisons and local authorities will also be included. While government is planning guidance for departments, at the moment there is little understanding of the implications of the scheme. The baseline for the CRC is the same year as the target year for the interim SOGE target which means departments may already have achieved many 등 carbon reductions, and may therefore have a more difficult starting point. Poor performance by public sector organisations in the scheme will result in the loss of large sums of public money to the other organisations in the CRC who may be starting from an easier starting point. This will include the private sector.
Government must immediately begin to prepare for participation in CRC post-2011. It should ensure that there is clear understanding of the scheme followed by development of carbon reduction initiatives beyond the interim SOGE target in order to ensure a competitive position in the scheme. However, it should be noted that the CRC also presents an opportunity for financial incentives to achieve top-level carbon reduction performances.

\section{Carbon neutrality/offsetting}

Despite ministerial approval for a renewed contract for the

Government Carbon Offsetting Fund (GCOF), a clear stance on carbon neutrality and carbon offsetting is still lacking. Given this current lack of clarity, the current commitment for the central government office estate to be carbon neutral by 2012 may cost the taxpayer millions of pounds in carbon offsetting per year.
The newly formed Department of Energy and Climate Change (DECC) is currently undertaking a consultation to define carbon neutrality; the consultation closes on 21st May 2009.iv On the back of this, government must produce a clear policy stance on carbon neutrality, carbon offsetting and zero carbon status. This must include advising public sector organisations on how and when offsetting can be used, must indicate how carbon emissions will be avoided and reductions continuously sought, and must ensure that any offsetting is used only as a part of an integrated strategy for carbon management. 
Heat v Electricity. Increase in electricity consumption (due to ICT?)

Government electricity usage is on the rise since the baseline and one of the key drivers may be the proliferation of

computers, printers, laptops, chargers, lobby televisions, mobile phones and other Information and Communications Technology

(ICT), as well as associated impacts e.g. air conditioning of server rooms as well as severe levels of waste in the disposal of old ICT (including toxic materials). Government must address the root causes of both the energy consumption rise and its increasing waste, to encourage industry to improve ICT equipment life span, eco-design and energy consumption ${ }^{v}$.
Whilst the existing Greening Government ICT Strategy (launched July 2008) represents an encouraging step towards making ICT usage more sustainable, government must consider urgently raising the ambition level of the Strategy as industry awareness and action has gathered around this agenda. The Chief Information officers and Chief Technology officers have responded well to the first set of targets but they must now be increased. The Strategy itself acknowledges there is a need to work with departments and industry to explore and invest in radical green ICT solutions, ${ }^{\text {vi }}$ but also to consider issues relating to life cycle impact and disposal of old IT hardware. Some solutions could include initiatives such as:

- Extended procurement cycles to a mandatory minimum of four years. Equipment replacement must be carefully evaluated and not judged on electricity usage alone but rather the wider $\mathrm{CO}_{2}$ output of the production, manufacturing and full lifecycle of the equipment as stated in the Strategy

- Reduce duplication of equipment per person. For example, cease allowing two computers per staff member

- Government and outsourced data centres must adhere to the basic principles included in the European Data Centre Code of Conduct to ensure server optimisation, the removal of over-duplication of data, as well as sharing data centres and using appropriate levels of ambient room temperatures in server rooms

- Ensure procurement of equipment at the highest international standards as well as working with supply chain to reduce unnecessary packaging.

v As an indication on the impact of ICT in data centres, please see: http://ec.europa.eu/information_society/activities/sustainable_growth/docs/com_2008_241_1_en.pdf

vi Pg. 7, Cabinet office, Greening Government ICT: Efficient, Sustainable, Responsible, July 2008 


\section{Performance against building standards is poor}

Sustainability in government buildings in terms of design and operations is poor. Pan-government figures continue to show poor performance against the BREEAM commitment which ensures certain sustainable standards in the design of buildings. Only $42 \%$ of total projects (new build and major refurbishments) have achieved the required standard. For some departments this may be because BREEAM does not account for their unique operations (e.g. rural based sites). In terms of operational performance, as of 1st October 2008 all public sector buildings with a total floor area of over $1000 \mathrm{~m}^{2}$ are required to have a Display Energy Certificate (DEC) showing the energy usage of a building and its operational rating from $A$ to $G$, A being the best and $\mathrm{G}$ the worstrii. At the end of October 2008 only $49.5 \%$ of the buildings which are required to have a DEC actually did, with 59\% of these buildings achieving a rating below the average benchmark (see Figure 6). Climate change adaptation, in addition to mitigation, is vital. As the climate changes, the demands on the estate infrastructure and energy consumption will increase; government must consider how it will respond to erratic weather changes and long-term temperature rises to maintain comfortable working conditions for employees.
Departments must continue to improve the standards of buildings to achieve greater energy efficiency (e.g. zero carbon new public sector buildings by 2018 as announced in Budget 08). This means achieving post-construction certificates for operations as well as meeting BREEAM (or more appropriate) standards for design. Departments must also ensure that consideration of the changing climate is taken into account in clearly defined sustainability appraisals applied to all new builds, major refurbishments, re-locations and estate rationalisation.

\section{Good Quality CHP}

Originally the SOGE target for CHP included the specification that energy sources from CHP must be of Good Quality viii. However, this stipulation was lost when the SOGE targets were agreed. The total CHP generated electricity consumed on the government estate in 2007/08 was 311 gigawatt hours however only 19 gigawatt hours comes from Good Quality CHP (GQCHP).

Therefore only $6 \%$ of the total CHP electricity consumed on the government estate in 2007/08 comes from good quality sources.

vii www.communities.gov.uk/planningand building/theenvironment/energyperformance/publiccommercialbuildings/displayenergycertificates/

viii A definition of Good Quality CHP can be found at the CHP Quality Assurance Programme site https://www.chpqa.com/guidance_notes/GUIDANCE_NOTE_10.pdf

Government must ensure that any new CHP plants brought online are of Good Quality standard, must update existing CHP plants to the Good Quality standard where reasonably practicable, and must register with the CHP Quality Assurance (CHPQA programme). 


\section{Lack of a pan-government travel strategy/plan}

The amount and accuracy of data relating to different modes of transport is variable. Rail travel data can be difficult to collect due to poor management information systems, while air travel data is often collected by travel providers to a high quality. However, analysis of

the road travel data still shows serious data quality issues, particularly in the application of the carbon conversion factors by some

departmental practitioners.

The UK targets to reduce carbon emissions now include aviation. As ai travel accounts for 36\% of government's total travel (Figure 7), and with long-haul flights making up the majority of this, this needs to be reflected in government's own framework to reduce emissions from all types of air travel. For some departments with clear international remits, the percentage of travel carbon emissions is understandably high (DFID - 98\%, FCO - 98\% and ECGD - 76\%). But other departments without such remits still show a much greater percentage than the pan-government average (CO - 87\% and FSA - 77\%).

There is a lack of government guidance to induce behaviour change and ensure individuals and departments take the most sustainable travel options.
Government must produce a clear pan-government travel strategy which provides mandates, guidance and information to departments to enable them to make sustainable travel decisions, including reducing the need to travel. A part of this strategy should be for a significant programme of investment in and encouragement for ICT solutions (such as videoconferencing), as well as providing guidance to the other support available, such as the Energy Saving Trust's green fleet programme. ${ }^{\text {ix }}$ The SDC is currently working in partnership with the Centre of Expertise in Sustainable Procurement (CESP) on a review of sustainable travel for the public sector and will make recommendations for future work.

\section{Air travel (not a target)/cheaper option than rail}

Domestic air travel is often cheaper than domestic rail travel.

Managers within government, operating to their allocated budgets, will naturally seek to get the most from those budgets and may therefore be inclined to choose the cheapest option for travel.
Government should implement controls restricting domestic/GB air travel, as well as flights to Paris and Brussels. These shorter flights should be avoided in the first instance using alternative forms of communication; however where this is not possible they should be taken using more sustainable methods of travel such as rail. As shown in Figure 7, this will reduce carbon emissions from domestic flights by up to $5 \%$.

ix www.energysavingtrust.org.uk/business/Business/Transport-in-business 
Civil Servants incentivised to drive own cars to work (grey fleet)

Mileage can be claimed at rates above fuel costs to account for wear and tear. However, this difference incentivises civil servants to drive their own cars for work.
Current travel strategies provide a perverse financial incentive for vehicle travel by allowing staff to claim mileage at rates above fuel costs. Instead, government should incentivise staff to use more sustainable methods of travel, or avoid travelling by working from home.

For example, a programme to partially reimburse home workers for household fuel bills would cut down on required office space, reduce workplace fuel bills and reduce commuter congestion.

Procurement of vehicles - target exists but does it go far enough?

The government's fleet consists mainly of small/medium diesel vehicles (Figure 8). Despite a target for new vehicle procurement of $130 \mathrm{gCO}_{2} / \mathrm{km}$, there is a lack of clear commitment to procure ultra-low carbon vehicles, as well as a lack of guidance to induce behaviour change to ensure the most sustainable travel options are taken.
The Low Carbon Vehicle Procurement Programme (LCVPP) represents a commitment by government to be a leader in the procurement of lower carbon vehicles, which the SDC welcomes. However, as the programme focuses on vans in the first phase $(£ 20 \mathrm{~m})$, government must broaden the commitment to include all sizes and types of ultralow carbon vehicles, including electric vehicles powered by renewable energy sources. The SDC recommends an announcement of a significantly larger fund in the future to replace government fleet vehicles with ultra-low carbon vehicles, which would help government meet its carbon reduction commitments, as well as stimulating innovation in the industry. To achieve real results in this area, government should consider an investment of $£ 250 \mathrm{~m}^{\mathrm{x}}$ in addition to the $£ 30 \mathrm{~m}$ earmarked for a subsequent phase of LCVPP.

x SDiG 08 data collected from departments indicates a government fleet size of 23,556 vehicles. As a proxy for ultra-low carbon vehicles, we have used the 2009 Ford Fiesta ECOnetic, which the government's Act on $\mathrm{CO}_{2}$ website lists as the most fuel efficient new car (www.direct.gov.uk/actonc02) at $98 \mathrm{gCO} / \mathrm{km}$. If $100 \%$ replacement is assumed, and using the current price of the Fiesta ECOnetic of $£ 12 \mathrm{~K}$ as a per unit estimate, the cost of such a programme would be $£ 283 \mathrm{~m}$. 


\section{Waste contracts and recycling}

Waste contracts and recycling services are not being used to their full capacity. Opportunities for collaborative procurement across government to share these contracts and services, where it would be beneficial, have not been fully recognised.

\section{Carbon impacts of waste}

Waste to landfill does feature in an organisation's carbon footprint and so reducing the amount of waste sent to landfill can reduce an organisation's carbon footprint.
While the primary emphasis must be on reducing the amount of waste produced in accordance with the waste hierarchy,

infrastructure to recycle is available and government has a duty to set and enforce contracts which make use of this infrastructure to its full capability.

Where waste volumes are low and costs are high, the use of inter-organisational waste contracts should be explored to achieve economies of scale. For example, larger volume waste streams could be undertaken on a more regional basis which allow for more cost effective and innovative waste and recycling solutions.

Work with producers and packagers

Any major public sector capital expenditure projects should seek to reduce aggressively waste arisings throughout product life cycles, as well as sharing knowledge of these processes both within government, and with the private sector. 


\section{Demand management through procurement}

The way in which we dispose of the resources and products we use has an enormous impact on the environment. Effective and responsible demand management is vital in reducing these impacts.

A high level of waste production and its associated impacts is not solved by greater levels of recycling. Reduction in the amount of waste produced should be the primary concern. There is a current 'waste gap' between the high levels of waste produced and more moderate levels of recycling Ulitmately, as waste production falls and waste recovery (e.g. external re-use, recycling, composting and energy from waste) increases, this gap should close.

\section{Landfill Tax}

The Landfill Tax rate for 2008/09 is £24 per tonne and will increase by $£ 8$ per year until $1^{\text {st }}$ April 2010. The escalation of this tax discourages the disposal of waste to landfill making recycling more cost effective. This would mean that at 2007/08 levels, the amount of waste after waste recovery

( 289,242 tonnes), if it is sent to landfill, would cost government $£ 6,941,815$ in $2008 / 09$ and rise to $£ 11,569,691$ in $2010 / 11$.
Government must advocate the use of sustainable procurement practices to better control the input of consumable materials into departmental operations, in addition to the positive contractual changes already made to manage the outflow of waste materials. Recycling is not the solution to the waste problem. 
The water footprint of the central government estate is largely unknown of SD need to be considered holistically to ensure decision-
An understanding of this is essential in considering the wider impacts of government's operational and procurement activity on water use.

Government and departments should begin to develop water footprints to help them understand the water consumption used through their operations and procurement practices, including embedded water in products.

Normalising this information into per person figures, as well as installing water meters, will allow departments to benchmark performance and identify areas for improved water efficiency in order to reduce overall water consumption.

\section{Water usage effected by other initiative (e.g. cycling to work)}

Water use may be affected by other initiatives intended to drive forward the sustainability agenda, such as the installation of showers to encourage staff to cycle to work. The larger benefits making is balanced and idenitifies all possible impacts.

To increase water efficiency across the estate, government should explore the possibility of setting up a spend-to-save scheme based on the Salix Fund energy efficiency scheme which uses a revolving public fund mechanism. The size of such a fund would be relatively small. Preliminary research indicates that a fund of around $£ 3 \mathrm{~m}$ for the public sector "water Salix" scheme could save roughly $20 \%$ of annual water use and have a payback period of less than a year.i Further research must be undertaken in order to make fully informed decisions.

xi Figures are based on discussions with water experts, and very roughly use $£ 0.50$ to $£ 1$ per person relative to the intensity of water usage at each site, e.g. offices at low end of the spectrum compared to hospitals and prisons at the high end. 


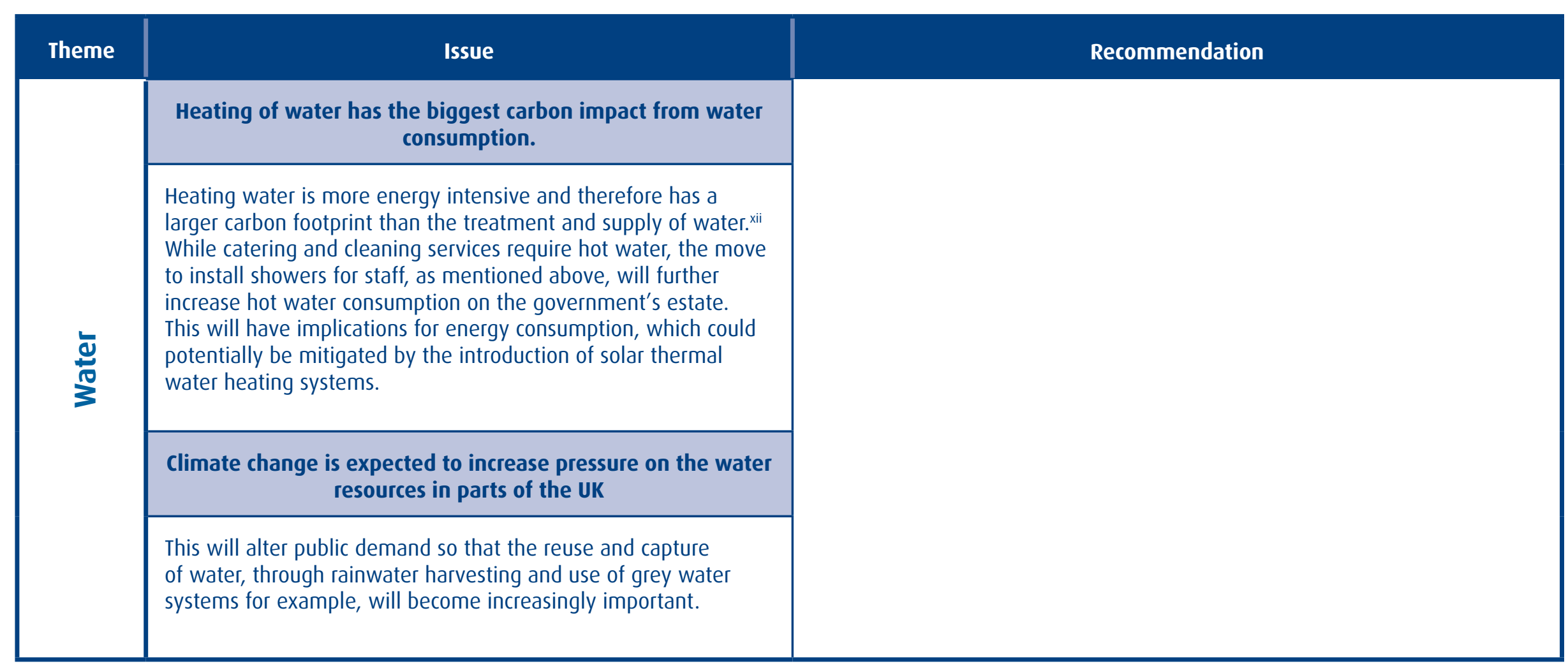

xii Defra's Water Strategy, 2007. 
Biodiversity is about more than the management of SSSIs

As a large landholder government should be looking beyond this target to identify ways in which it can more comprehensively consider the diverse and dynamic nature of biodiversity throughout its estates and operations.

Favourable performance against this target depends on an annual assessment conducted by Natural England of one of the SSSI features at one unit of the SSSI. The feature assessed at any one annual assessment may be different from the previous assessment, resulting in a lack of continuity. This variation of assessment adds a layer of uncertainty as to whether government will achieve the target.

Just over half of all land holdings are designated SSSIs and are therefore included in biodiversity targets. As the scope of this target is limited to SSSIs, a significant $44 \%$ of government's landholdings are not accounted for, limiting the potential for improving the quality of these landholdings and promoting biodiversity across the government's estate.
Some departments already use site or area management plans; however government should consider more detailed indicators, such as the GRI biodiversity indicators, to further monitor and report performance beyond the SSSI target. Departments should encourage staff engagement with green spaces as a way of improving understanding of the importance of biodiversity as well as engendering associated social and health benefits. Furthermore, as a large landholder, government needs to encourage biodiversity as a key indicator of what it grows and how it grows it.

\section{Not all departments are biodiversity experts}

They may not necessarily have the appropriate expertise to

effectively manage and conserve the biodiversity of their estate.
Government departments such as MOD and the Forestry Commission have unique expertise on biodiversity issues on government-owned land.

Their experience, alongside Defra specialists (including the statutory nature conservation specialists), should be used to inform the wider government and public sector estate, so that all landholders encourage biodiversity and share best practice. 


\begin{tabular}{|c|c|c|}
\hline Theme & Issue & Recommendation \\
\hline \multirow{5}{*}{ 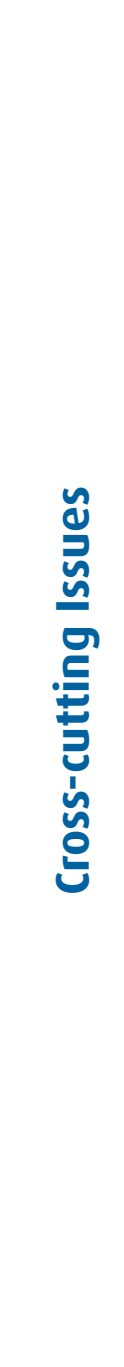 } & \multicolumn{2}{|r|}{ SD Reporting and Governance } \\
\hline & $\begin{array}{l}\text { Proliferation of reporting methodologies on } \\
\text { sustainable development }\end{array}$ & $\begin{array}{l}\text { With the increasing number of SD-related reporting requirements, government needs to } \\
\text { standardise and improve SD reporting methods to reduce the burden on organisations } \\
\text { and to develop a greater understanding of sustainability impacts, which will enable } \\
\text { further progress. }\end{array}$ \\
\hline & $\begin{array}{l}\text { Confusing governance structure in government on the } \\
\text { sustainable development agenda }\end{array}$ & $\begin{array}{l}\text { While the creation of the government's Centre in Expertise for Sustainable Procurement } \\
\text { (CESP) has sharpened government's focus on improving sustainable operations and } \\
\text { procurement, this has resulted in an increasingly complex governance structure for } \\
\text { the wider sustainable development agenda and has increased confusion in roles and } \\
\text { responsibilities. Government, in consultation with the SDC, must urgently review the } \\
\text { structures in place, clarify roles and responsibilities, and produce a simplified governance } \\
\text { plan, including clarity over how operational and policy initiatives relate to each other and } \\
\text { are co-ordinated. }\end{array}$ \\
\hline & \multicolumn{2}{|r|}{ The SOGE Framework } \\
\hline & Scope of assessment & $\begin{array}{l}\text { The current SOGE framework applies to the UK-based operations of all central government } \\
\text { departments and their executive agencies (EAs). As well as typical administrative } \\
\text { functions expected of government departments, the report captures less obvious } \\
\text { operations such as prisons, courts, job centres and the Royal Parks. Departments are also } \\
\text { encouraged to include self-selected non-departmental public bodies (NDPBs) in the scope } \\
\text { of their reporting. The targets largely exclude: } \\
\text { - The overseas estate (for example FCO posts). However, one exception is the MOD, } \\
\text { which has reported data from some of its overseas operations } \\
\text { - The devolved administrations (DAs) for Wales, Scotlandxiii and Northern Ireland } \\
\text { (although some activities of the central Whitehall departments are located in the } \\
\text { DAs; for example MOD bases and DFID's East Kilbride office). } \\
\text { - The wider public sector: local government, NHS trusts, police forces and } \\
\text { constabularies, and educational establishments. }\end{array}$ \\
\hline
\end{tabular}

xiii The sustainable development performance of the Scottish Government, including consideration of its own operational performance, has been assessed and reported by the SDC in Sustainable Development: A review of progress by the Scottish Government, SDC, November 2008. 


\begin{tabular}{|c|c|c|}
\hline \multirow{2}{*}{ 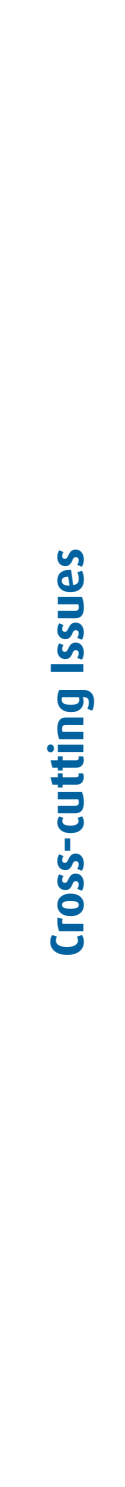 } & Insufficient and confusing assessment coverage and structures & $\begin{array}{l}\text { Given that the requirement for central government departments and their } \\
\text { executive agencies (EAs) to report dates back to the previous assessment } \\
\text { framework (2001/02), it remains hugely disappointing that there is not yet } \\
100 \% \text { coverage. This year } 47 \text { of a total of } 56 \text { EAs }(84 \%) \text { reported as a part } \\
\text { of the SDiG process. This is down } 1 \% \text { from last year. This points to a larger } \\
\text { problem of exactly which government bodies are included in this process. } \\
\text { There has been some confusion over the classification of certain government } \\
\text { bodies as to whether they are classified as EAs, and confusion also over } \\
\text { whether non-ministerial departments come under the umbrella of 'central } \\
\text { government departments'. Many government bodies therefore still do not } \\
\text { report on their impacts through the sDiG process as it has never been made } \\
\text { clear exactly who is included. Government should undertake a review of } \\
\text { coverage so that it is clear who is in and who is out of the scope of the } \\
\text { assessment. Ultimately the aim should be for } 100 \% \text { coverage of all central } \\
\text { government departments, Executive Agencies, NDPBs and other bodies. } \\
\text { There is also a need for greater granularity of performance data within the } \\
\text { wider departmental family so that individual agencies' and organisations' } \\
\text { performance can be separated out from that of the larger department. }\end{array}$ \\
\hline & Urban bias of the SOGE targets & $\begin{array}{l}\text { The SOGE targets were primarily designed with urban-based office sites in } \\
\text { mind, so departments with dispersed, largely rural estates, for example the } \\
\text { Forestry Commission and the Ministry of Defence often have unique difficulties } \\
\text { and challenges in meeting the targets. A better understanding of the } \\
\text { differences between the estates of individual departments, and the different } \\
\text { ways in which they should be managed, is required. }\end{array}$ \\
\hline
\end{tabular}




\begin{tabular}{|c|c|c|}
\hline Theme & Issue & Recommendation \\
\hline \multirow{4}{*}{ 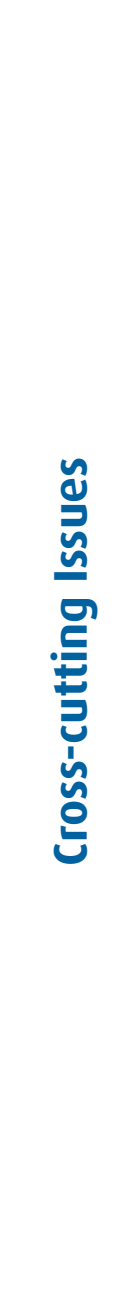 } & Tenancy/landlord issues & $\begin{array}{l}\text { Some departments have difficulties with meeting targets where they are } \\
\text { not the sole occupier or owner of a building. Government should offer a } \\
\text { programme to incentivise existing private landlords to work with public } \\
\text { sector tenants to ensure that government's targets are met. Departments } \\
\text { should also ensure that new rental contracts are entered into only for } \\
\text { buildings which meet the highest building standards. For example, those } \\
\text { having a Display Energy Certificate (DEC) above the average benchmark, } \\
\text { i.e. with a rating of A, B,C or D. }\end{array}$ \\
\hline & \multicolumn{2}{|r|}{ Data issues } \\
\hline & Data quality & $\begin{array}{l}\text { Data quality remains a concern, with many instances of errors and } \\
\text { clarifications required to produce a final dataset. This emphasises the need } \\
\text { for external verification of data before it is signed-off within departments. } \\
\text { Government must also ensure that rigorous, centralised verification of the } \\
\text { entire dataset is undertaken before sign-off. }\end{array}$ \\
\hline & Data collection & $\begin{array}{l}\text { For the past three years the SDC has gathered the performance data for } \\
\text { SDiG as reported by departments through an online data collection platform. } \\
\text { However, this has always remained government's data, not the SDC's. } \\
\text { Last year the OGC and CESP worked with the SDC to use an existing central } \\
\text { government property database, e-PIMS, to collect data. This year data } \\
\text { collection is being fully transferred back to government for the period covering } \\
2008 / 09 \text { and will be collected centrally by CESP using a more advanced } \\
\text { questionnaire via e-PIMS in future years. Not only will this reduce the } \\
\text { reporting burden on departments by allowing data used for different purposes } \\
\text { to be collected just once, this will also engender greater ownership and } \\
\text { responsibility for the data which should in turn improve data quality. } \\
\text { This will be extremely important as data quality remains an issue - particularly } \\
\text { on travel and waste. }\end{array}$ \\
\hline
\end{tabular}


Historical data (EMS) mean that historical data is often not of a high quality. The SDC oversaw a process for improving the quality of data through reviewing departmental baselines for the SOGE targets. The SDC produced guidance for departments detailing when

"rebaselining" is appropriate, as well as chairing a panel (including CESP and Defra) to approve rebaselining cases. With over 40 cases approved, data quality has improved in many cases, but remains varied across departments and by theme. Government should ensure that for any future Machinery of Government changes, the process of rebaselining is undertaken.

\section{Review of the SOGE Framework}

Government is currently undertaking a review of the SOGE Framework to improve its robustness. The SDC supports the review, as several of the targets government departments are required to meet have conflicting and not altogether comprehensive outcomes, or are no longer challenging enough. In particular:

- There is an issue with the way in which the energy efficiency target is measured, that is, energy use per $\mathrm{m}^{2}$. Progress against the energy efficiency target may be positive and progress against the carbon reduction target negative if increased energy consumption is proportionally smaller than increased floor space. The overriding aim for each department should be to reduce energy consumption and reduce carbon emissions. However, it is possible to increase energy consumption and still show a positive performance against the energy efficiency target.

- The waste and recycling targets are not ambitious enough. On the whole, departments have shown that these targets are highly achievable and so applying more challenging targets will deliver greater benefits over time.

- The water consumption in the new build/major refurbishments target is problematic because the value threshold for inclusion in the major refurbishment programme is $£ 0.5$ million and higher. In many cases this may include refurbishments which are purely decorative and so do not affect the water infrastructure of a building.

- The current biodiversity target concerns only SSSIs, and only specific features of these SSSIs. As SSSIs account for just over half of government's landholdings, a more comprehensive target is required to cover all of these landholdings in order to promote biodiversity across the government's estate. 


\begin{tabular}{|l|l|l|}
\hline \multicolumn{2}{|c|}{ Issue } & \multicolumn{2}{|c|}{ Recommendation } \\
\cline { 2 - 4 } & Behaviour change & $\begin{array}{l}\text { The way in which the government and the public sector operate has an } \\
\text { impact far beyond any direct impacts on carbon emissions, water use and } \\
\text { so on. Transforming its operations and supply chains will have a powerful } \\
\text { multiplier effect on all those who work in the public sector, citizens when } \\
\text { they are using public services and the huge variety of businesses and social } \\
\text { enterprises which supply goods and services. }\end{array}$ \\
\cline { 2 - 4 } & Social impacts & $\begin{array}{l}\text { These are not measured through the current soGE Framework. As a part of } \\
\text { improved and standardised reporting methodologies, government should } \\
\text { work with practitioners to improve the way in which social impacts are } \\
\text { measured and quantified on and off-site, and through supply chains. }\end{array}$ \\
\cline { 2 - 4 } & The impact of a department on SD & $\begin{array}{l}\text { The SDC's intention is to undertake more in-depth assessments to } \\
\text { evaluate the overall contribution to sustainable development made by } \\
\text { individual departments. This will includes policies as well as operations } \\
\text { and procurement and will build on the evidence as provided through } \\
\text { the SDiG process and the SDC's assessment of departmental Sustainable } \\
\text { Development Action Plans (SDAPs). }\end{array}$ \\
\hline
\end{tabular}




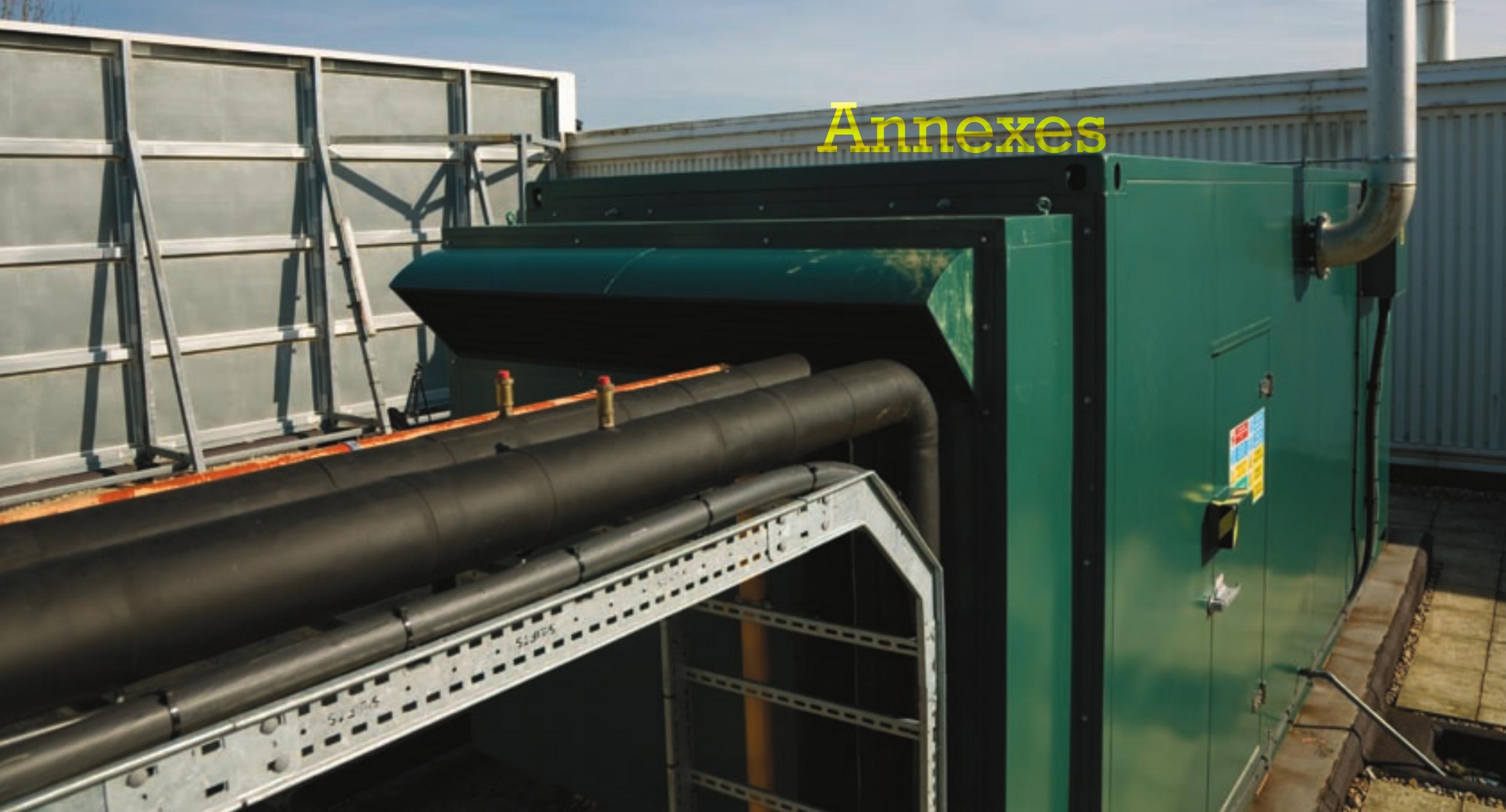




\section{Annex A}

\section{Sustainable Operations on the Government Estate (SOGE) framework}

In 2006, government developed a new framework for assessing the sustainability of its own operations - the Sustainable Operations on the Government Estate (SOGE) framework. This replaced the 2002 Framework for Sustainable Development on the Government Estate (SDGE). The SOGE framework consists of three elements:

- SOGE targets - 14 outcome-orientated performance targets to support delivery of three of the four UK sustainable development strategy's shared priority areas for immediate action. ${ }^{29}$ In addition, two targets have been carried forward from the former SDGE framework, as target dates had not been reached. These targets relate to acquiring electricity from renewable and combined heat and power sources

- Eight 'Government to Mandate' requirements - covering mechanisms that departments should adopt to help deliver the SOGE targets, improve data collection and reporting, and broaden out the targets. One of the eight requirements was to mandate "accepted elements from the Sustainable Procurement Task Force National Action Plan", as subsequently published in the Sustainable Procurement Action Plan (SPAP)
- Commitments from Annex B of the SPAP, covering leadership and accountability on sustainable procurement, budgeting and accounting practice, building capacity, raising standards and supplier engagement.

The first two elements applied to the reporting period April 2006 to March 2007; and the third became applicable on publication of the SPAP in March 2007.

The full list of SOGE requirements is provided in Tables B.1- B.3, mapped against the former targets from the SDGE Framework.

Table B.1 SOGE Targets - Performance Focussed Targets mapped to former Framework Targets

\begin{tabular}{|c|c|c|}
\hline Theme & SOGE targets & Previous SDGE Targets \\
\hline \multirow{4}{*}{ 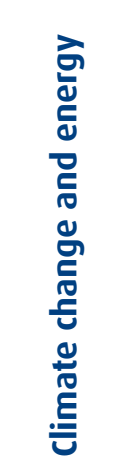 } & \multicolumn{2}{|c|}{ Carbon emissions from offices } \\
\hline & $\begin{array}{l}\text { Reverse the current upward trend in carbon emissions } \\
\text { by April } 2007 .\end{array}$ & N/A \\
\hline & $\begin{array}{l}\text { Reduce carbon emissions by } 12.5 \% \text { by } 2010-11 \text {, } \\
\text { relative to } 1999 / 00 \text { levels. }\end{array}$ & $\begin{array}{l}\text { Government departments to reduce absolute carbon, from fuel and electricity } \\
\text { used in buildings on their estate by } 12.5 \% \text { by } 2010 / 11 \text {, relative to } 1999 / 00 \text {. }\end{array}$ \\
\hline & $\begin{array}{l}\text { Reduce carbon emissions by } 30 \% \text { by } 2020 \text {, relative to } \\
1999 / 00 \text { levels. }\end{array}$ & \\
\hline
\end{tabular}




\section{Carbon emissions from road vehicles}

Reduce carbon emissions from road vehicles used

for government administrative operations by $15 \%$

by $2010 / 11$, relative to $2005 / 06$ levels.

Reduce road transport vehicle $\mathrm{CO}_{2}$ emissions by at least $10 \%$ by 31 March 2006

(against a baseline year of 2002/03), to be achieved through any combination of three options:

- Reducing total business vehicle mileage

- Improving the average fuel efficiency of vehicles and

- Reducing total fuel consumed.

\section{Carbon Neutral}

Central government's office estate to be carbon

neutral by 2012 .

N/A

Energy Efficiency \& Renewables

Departments to increase their energy efficiency per $\mathrm{m}^{2}$ by $15 \%$ by 2010 , relative to $1999 / 00$ levels.

Government departments to increase the energy efficiency of the buildings on their estate, measured in terms of kWh of 1) fuel and 2) electricity use per square metre of building floor area,(1) or estate area, by $15 \%$ by $2010 / 11$ relative to $1999 / 00$.

Departments to increase their energy efficiency per $\mathrm{m}^{2}$ by $30 \%$ by 2020 , relative to $1999 / 00$ levels.

\section{Existing Sustainable Operational Commitments (to continue until completion)}

Departments to source at least $10 \%$ of electricity from renewables (31 March 2008).

Departments to source at least $15 \%$ of electricity from Combined Heat and Power (CHP) (2010).
Government departments are required to source at least $10 \%$ electricity from renewable sources by 31 March 2008 (2010 for the MOD). This will be measured by kilowatt hours for:

- Purchasing of renewable electricity; and

- Self-generation of renewable electricity (excluding CHP).

Source at least 15\% electricity from Good Quality Combined Heat \& Power (GOCHP) by 2010 (with allowances for departments that already purchase 100\% renewable energy).

(1) Due to the diversity of the government estate, departments can report using either the floor area of their buildings, or the total estate area 


\section{Water arisings}

Departments to reduce their waste arisings by $5 \%$ by 2010 , relative to $2004 / 05$ levels.

Departments to reduce their waste arisings by $25 \%$

by 2020 , relative to $2004 / 05$ levels.

\section{Recycling}

Departments to increase their recycling figures to 40\% of their waste arisings by 2010 .

The target for D4 is that as soon as recycling/composting figures from Target D2 have been established at a site or a unit of establishments, departments should increase these rates by at least 5\% per annum with the aim of reaching 75\% recycling/composting rate overall. Where possible, this should be extended to each type of waste arising generated.

Departments to increase their recycling figures to

$75 \%$ of their waste arisings by 2020 . 


\section{Biodiversity}

Departments to meet or exceed the aim of having

$95 \%$ of Sites of Special Scientific Interest (SSSIs) in sole

The $\mathrm{H} 4$ target requires departments that own SSSIs to achieve at least $68 \%$

'favourable' or 'unfavourable recovering' conditions status on sites by 2006,

ownership or control in target condition by 2010.

and $95 \%$ by 2010. 'By 2006' has been interpreted as being by 1 January 2006.

\section{Water consumption}

Reduce water consumption by $25 \%$ on the office and non-office estate by 2020 , relative to 2004 /05 levels.

Reduce water consumption in office buildings where the department is the sole occupier or is billed for water services to an average of $7.7 \mathrm{~m}^{3}$ per person per year by 31 March 2004; and to $7 \mathrm{~m}^{3}$ per person per year for all new buildings and major refurbishments where design commences after 2002.

Reduce water consumption to an average of $3 \mathrm{~m}^{3}$ pe

person/year for all new office builds or major office

refurbishments. (2)

(2) This will be a one off assessment for the first year of occupancy. 


\section{Table B.2 SOGE Government to Mandate Requirements mapped to former SDGE Requirements}

\section{Government to mandate}

Previous SDGE Target

Departments to adopt the Carbon Trust's Carbon

Management Programme - involves the proactive

management of the risks and opportunities relating

to climate change mitigation. (1)

The application of Building Research Establishment Environmental Assessment Method (BREEAM)

excellent standards, or equivalent, to all new builds and major refurbishments. (2)

Departments will incorporate a full range of sustainable development considerations into all new build and major refurbishment construction projects where design commences

on or after 1 December 2005. These projects should incorporate the targets and principles laid out in the government's Common Minimum Standards for the Procurement of Built Environments, and follow the guidance laid out in the OGC Achieving Excellence in Construction Guide 11: Sustainability.

Accepted elements from the Sustainable

Procurement Action Plan (SPAP).

\section{F1 Sustainable Procurement}

Departments were required to draw up either a Sustainable Procurement Strategy or Review in place by 1 December 2005.

\section{F2 Environmental Clauses}

Where legitimate and in accordance with the Joint Note on Environmental Issues in Purchasing, departments must include clauses relating to environmental considerations in all contracts for goods, works and services. These clauses should be for the life of the contract and ensure compliance of the product or service with other sections of the Framework. This target applies to all contracts including partnership contracts. When developing contracts, departments should include the principles laid out in relevant documents.

\section{F3 Training}

Departments should develop and implement appropriate training and awareness programmes on sustainable procurement for procurement staff, senior management and other staff with responsibility for procurement. 
The Office of Government Commerce's (OGC)

Property Benchmarking Scheme - aimed at

$\mathrm{N} / \mathrm{A}$

improving the efficiency and effectiveness of corporate estate management. (3)

Departments to work towards an accredited certified Environmental Management System (EMS) such as IS01401 or EMAS. (4)

There are two different time-scales set depending on the type of estate: For mainly office-based estates:

All main offices (more than 50 staff) - EMS required by 31 March 2004 All other offices/sites (including mixed and non-office sites) by 31 March 2006

For mixed and non-office estates:

40\% estate should be covered by 31 March 2004

$80 \%$ estate should be covered by 31 March 2006

Data collection and reporting - identification of core data to be reported against the new

By April 2003, all departments should have had arrangements in place to report publicly on their sustainable development impacts and to targets. verify their performance data.

All departments to encourage staff to take an active role in volunteering in the community.

All departments to conduct sustainability appraisals of office relocations.

Departments must draw up a strategy by 31 March 2006 that sets out how it will identify, assess and monitor significant social impacts that arise from the management of its land, building and operations. This strategy should include procedures to ensure that proposals to significantly change the management of land and buildings take account of potential impacts on staff and communities. Strategies should be published on departmental websites.

(1) Those departments which have signed up to the Carbon Trust's Energy Efficiency Programme would be viewed as having fulfilled this requirement.

(2) In conjunction with BREEAM guidance, departments are to define what constitutes new build and major refurbishment for their own estate. An environmental assessment process such as BREEAM or an equivalent (e.g. CEEQUAL, DREAM etc.) appropriate to the size, nature and impact of the project must be carried out on all projects. Where BREEAM is used, all new projects are to achieve an "excellent" rating and all refurbishment projects are to achieve at least a "very good" rating, unless site constraints or project objectives mean that this requirement conflicts with the obligation to achieve value for money. Where an alternative environmental assessment methodology is used, projects should seek to achieve equivalent ratings.

(3) The scheme is already collecting data on a government building by building basis - consideration will need to be given how the new targets' data should be collected to avoid duplication of effort.

(4) This does not mean departments must replace their existing EMS. Departments can decide whether to implement an accredited certified EMS for their whole estate, or in selected buildings only. 


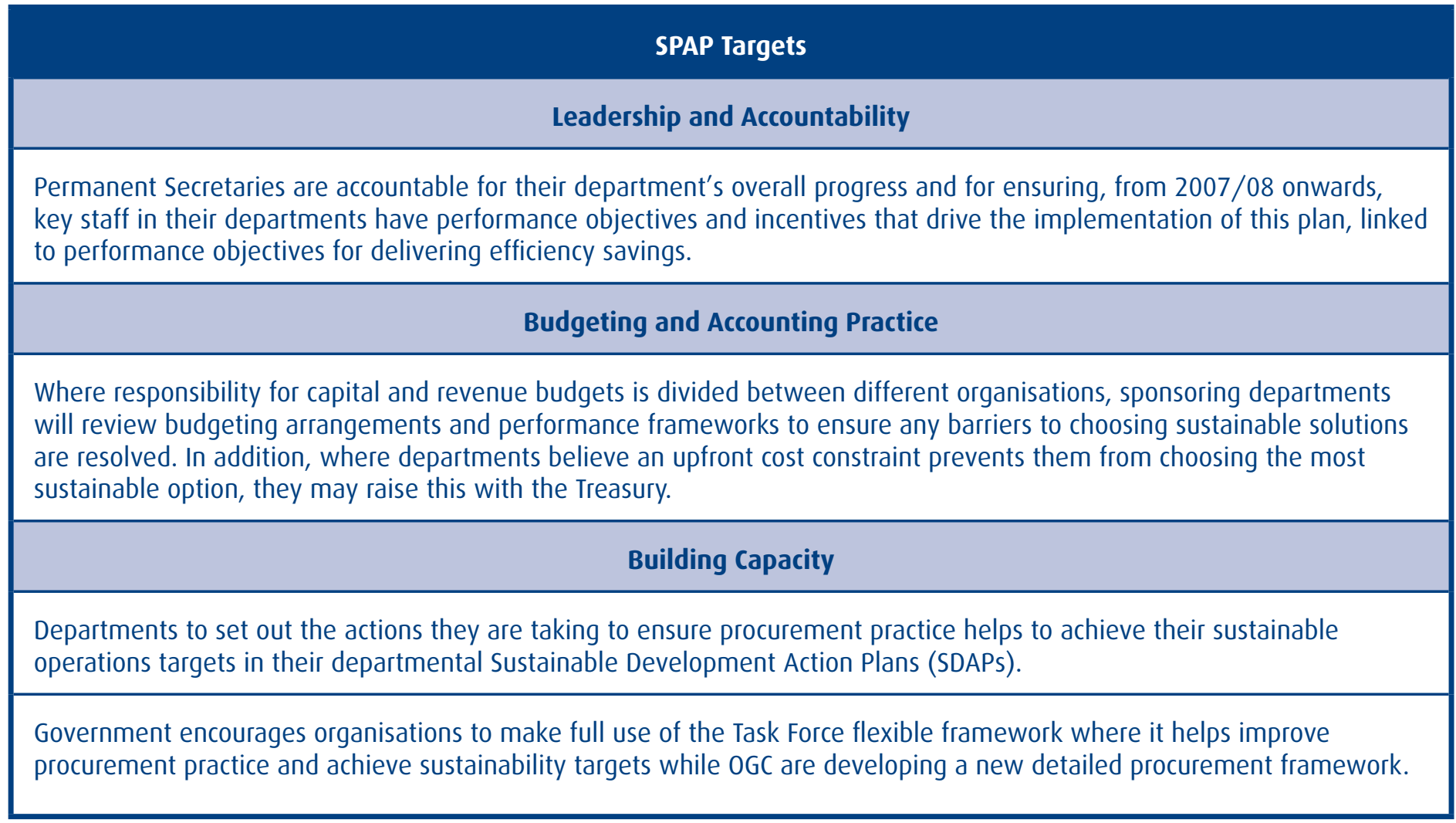


Departments/OGC to take action in respect of central government contracts to meet updated and extended mandatory standards.

Existing contracts will be updated as soon as is practical.

New contracts will be required to meet these standards.

Steps will be taken to remove offers that fall below these standards from framework agreements within 12 months (where permissible under existing contract terms).

Departments will make use of pan-government collaborative contracts in key areas to achieve compliance.

New government contracts, where relevant, will include appropriate requirements for suppliers and sub-contractors to provide products and services that comply with agreed mandatory standards and assist in the delivery of departmental sustainable operations targets.

From 1 April 2009, only timber and timber products originating either from independently verified legal and sustainable sources or from a licensed FLEGT partner will be demanded for use on the government estate - appropriate documentation will be required as proof. From 1 April 2015, only legal and sustainable timber will be demanded.

OGC will help departments achieve their sustainable operations targets through supporting the development of pangovernment procurement of goods and services, required to meet the sustainable operations targets.

\section{Market Engagement and Capturing Innovation}

OGC and government departments will work together to strengthen their strategic engagement with key sectors to ensure key suppliers have plans in place to lower their carbon footprint and that of their supply-chains. 


\section{Annex B - Case studies}

The following case studies were collected from departments and are reproduced verbatim.

\section{Carbon}

\section{Central Science Laboratory (CSL)}

\section{Carbon reduction schemes}

"CSL are committed in our core values to implement sustainable development throughout the core business activities and general operations, and alongside other areas. Carbon reduction is a key priority in achieving this.

In the last reporting year we have proactively implemented a wide array of carbon reduction schemes across our York laboratory site, resulting in savings in carbon dioxide emissions now totalling $10.48 \%$ on the baseline target year of 1999/2000. We have been able to achieve this by establishing an effective structure for enhancing sustainability issues, through committed buy-in from our Chief Executive, collaboration between our Estates team, on-site suppliers, scientific experts and Defra's Built Environment Sustainability Team (BEST).

Along with numerous smaller scale carbon reduction initiatives CSL have implemented 2 major schemes: installing a $230 \mathrm{kWp}$ Combined Heat \& Power (CHP) unit (pictured left and right) and 5 PowerPerfectors. The successfully installed CHP unit is now generating $10 \%$ of the site's electricity load, which is predicted to reduce the site's $\mathrm{CO}_{2}$ emissions by 340 tonnes a year.
In conjunction with the carbon reduction initiatives CSL have also successfully implemented other sustainability schemes, to continually improve our site performance, including:

- Sustainability Awareness Week: holding a Sustainability Awareness Week, using a host of media and guests to prompt staff interaction on energy, water, waste and the environment. This was a real success, leading to many useful suggestions and initiatives on ways of improving sustainability

- Sustainable Catering: being the first Government Agency to use the Defra Public Sector Food Procurement Initiative (PSFPI) toolkit to increase locally sourced food, improve healthy and nutritious choice and reduce waste output

- "Follow-me" Printers: replacing independent photocopiers with efficient centrally located Multi Functional Devices, to include default double-sided printing and 


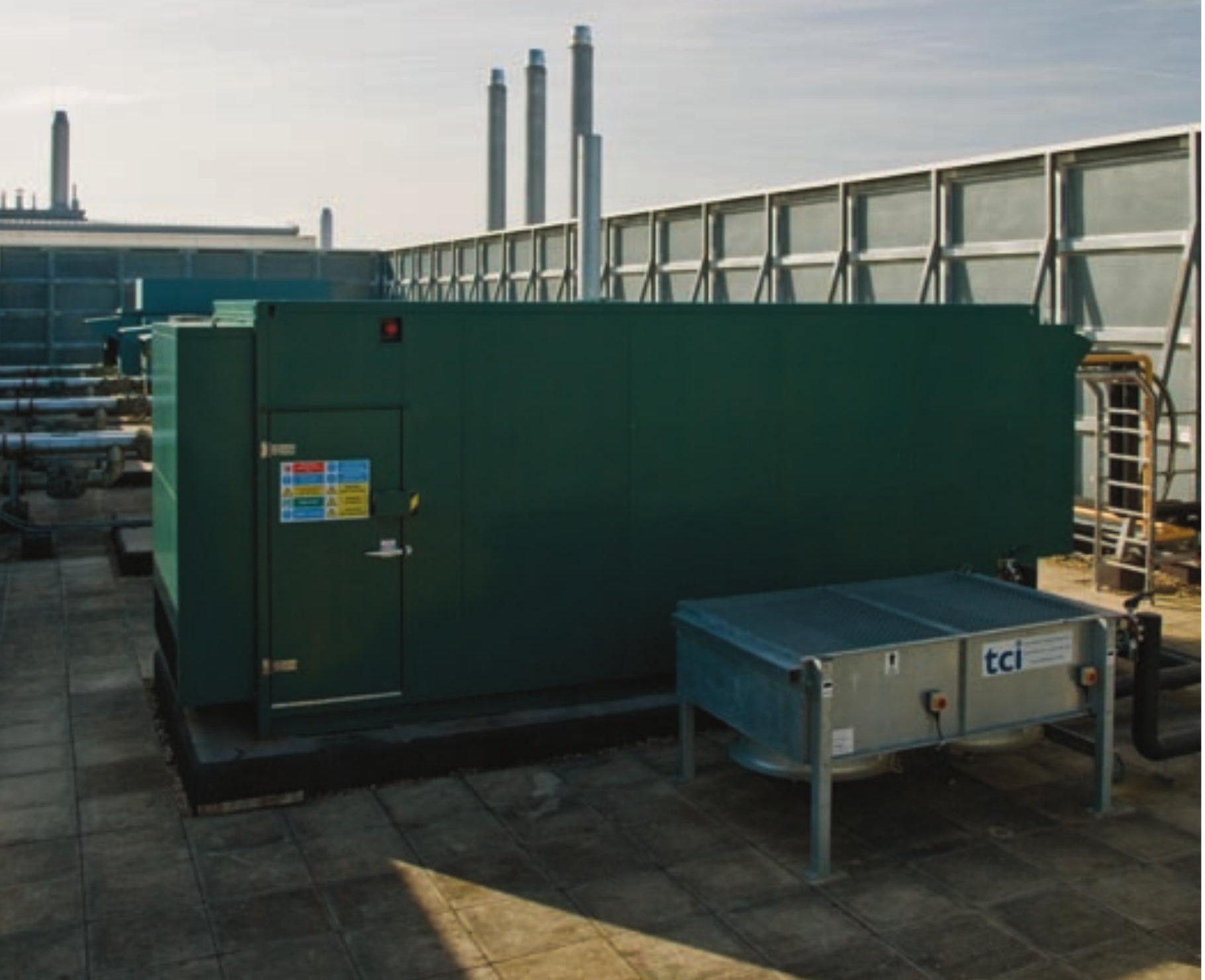

enhanced scanning, enabling staff to input or receive prints across the whole site. These have already shown savings on paper usage of $25 \%$

- Waste Reduction: achieved an $11.58 \%$ reduction in overall waste. This success was attributed to a higher profile campaign of waste sorting and collection

- Waste Recycling: a 7.22\% improvement was achieved by increasing the number of recycling stations around site and by also offering more waste streams for recycling. Integral to the overall site reduction figure was the full utilisation of the site composting facility. A further initiative was the introduction of a small wormery

- Biodiversity Group: established to encourage sustainable site landscaping and wildlife

All of these schemes and initiatives have helped to raise awareness and embed sustainability across site and the Agency as a whole, at the same reducing our site's carbon footprint." 


\section{Energy}

\section{Department for Children, Schools and Families (DCSF)}

\section{Flexible Workspace Project}

"In addition, the majority of waste from the project has been re-used or recycled to minimise environmental impact.

The circa $£ 11 \mathrm{~m}$ contract was awarded to Cofathec by $\mathrm{E} C$ Harris on behalf of DCSF, following an OJEU tender process. Subsequently, the three organisations have worked closely together in partnership to ensure smooth implementation and accommodation of design changes as the project proceeded.

The refurbishment project was instigated to reduce DCSF's carbon footprint while helping to create more efficient and flexible office space within the building and make it easier to accommodate fluid working practices. It has also enabled DCSF to vacate another building and thus reduce its overheads.

Sustainability was a key criterion for the project, in terms of both ongoing energy consumption and the construction process itself. This had to be achieved without replacing central building services plant, while also minimising disruption to DCSF staff in the building.

\section{Barriers}

The major challenges facing the project team were to achieve maximum energy performance within the constraints imposed by the listed status of the building, working with existing systems and ensuring that occupied areas of the building were not disrupted.

As well as requiring control of noise levels, this necessitated detailed co-ordination of every aspect of the project with close liaison between DCSF, EC Harris and Cofathec. For example, materials deliveries were minimised through precise scheduling, thus reducing disruption and the carbon emissions associated with transportation.

This has been achieved by daily, and often more frequent, liaison between all parties, bolstered by a shared commitment to 'get the job done' on time and without contractual wrangling.

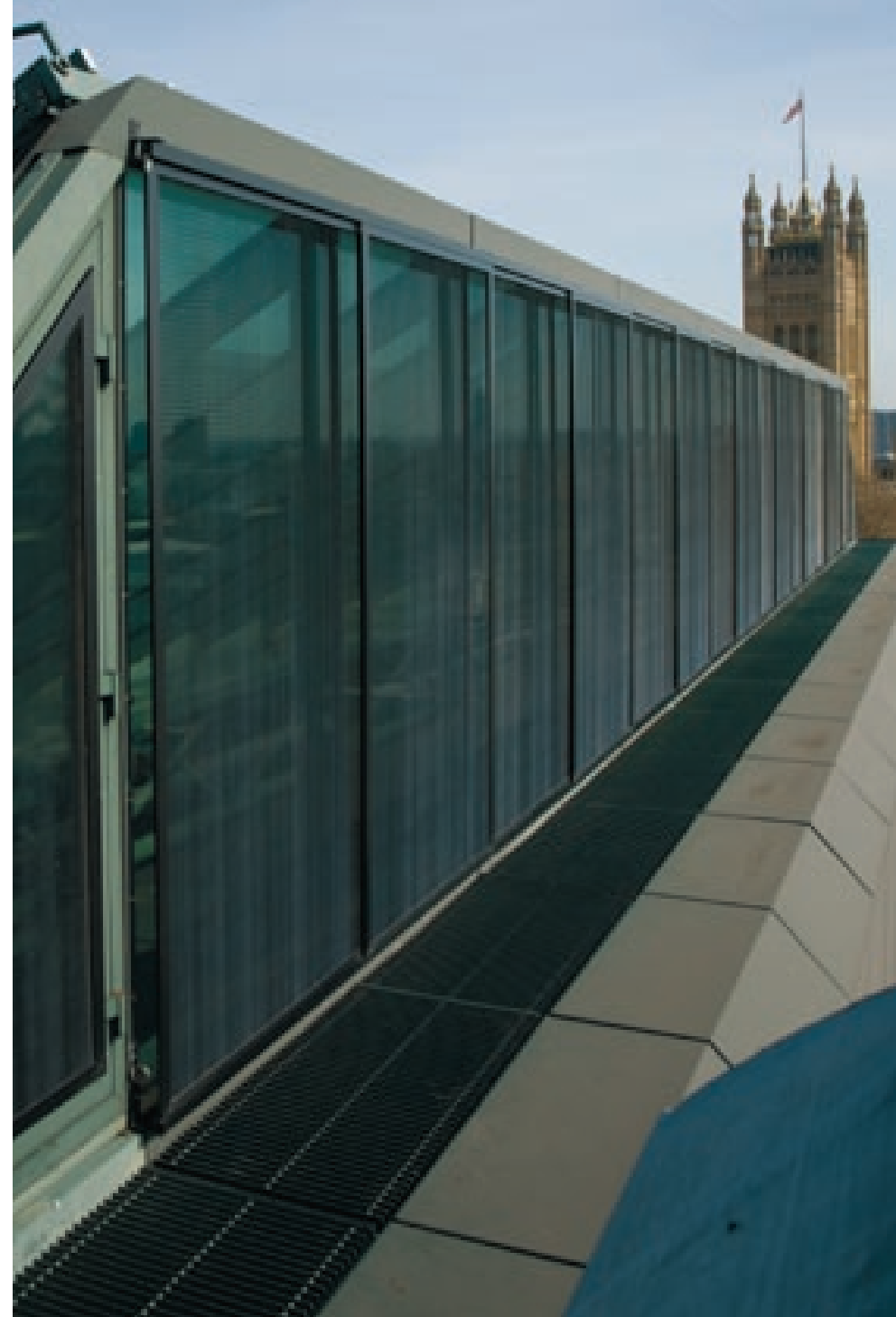




\section{The outcomes and benefits}

The combination of all energy efficiency improvement measures has resulted in significant energy savings, compared to the previous situation, which are summarised in the table, right:

Energy efficiency improvements have been introduced in a number of areas, including:

- Fine-tuning of existing central plant to optimise performance

- Installation of a new building management system (BMS)

- Replacement of existing fan coil system with a more efficient system (pictured right), incorporating DC motors and more precise control through the new BMS, resulting in around 25\% energy reduction, expected to be equivalent to $25,249 \mathrm{kWh}$ per annum

\section{Re-use and recycling}

For example, carpet that was in reasonable condition has been donated to charities for refurbishment and re-use in the UK and overseas, while non-salvageable carpet has been shredded for thermal insulation.

Similarly, metal from the ceiling grids have been recycled, while ceiling tiles have been sent to a ceiling tile manufacturer for shredding and re-introduction into the raw material mix for manufacturing new ceiling tiles.

In the case of furniture, some has been re-used in other DCSF buildings with the remainder being

\begin{tabular}{|r|l|}
\hline Lighting Energy Saving & 39,617 kWh per annum \\
\hline Fan Coil Unit Energy Saving & 25,249 kWh per annum \\
\hline Total Energy Saving & $64,865 \mathrm{kWh}$ per annum \\
\hline $\begin{array}{r}\text { Total } \mathrm{CO}_{2} \text { savings } \\
\text { @ } 0.422 \mathrm{~kg} / \mathrm{kWh}\end{array}$ & $\begin{array}{l}27,373 \mathrm{~kg} \mathrm{CO} \mathrm{CO}_{2} \\
\text { per annum }\end{array}$ \\
\hline
\end{tabular}

- Installation of solar shading to the atrium (pictured left) reducing heat gains to the building interior

- Installation of improved solar blinds to external office windows to reduce solar gain to the building fabric

- Addition of condensate removal system to enable lower chilled water temperatures, so that chillers can run at maximum efficiency with reduced chilled water flow rate and reduced pump energy

sent to Green Works, a not-for-profit organisation specialising in the refurbishment and re-distribution of used office furniture.

All luminaires, lamps and control gear have also been recycled in compliance with the WEEE Directive.

The majority of projects that achieve significant energy savings involve replacement of very old central plant, creating a highly favourable comparison.

We believe this project stands out from the crowd because it has achieved substantial improvements
- Installation of a more efficient lighting system with improved photometrics and using high frequency control gear, resulting in a saving of around 39,617kWh per annum

- Improved zoning of lighting to allow more precise control

- Introduction of PIR occupancy detection to switch lighting off in unoccupied zones.

- Occupancy control of urinal flushing and taps on hand basins

- The refurbishment also included replacement of furniture, ceilings and carpets which, wherever possible were re-used or recycled.

in energy efficiency by paying close attention to every other aspect of the building's services while retaining existing plant. This approach also helped to minimise disruption to staff in the building.

In addition, the Sanctuary Buildings project has broken new ground in the proportions of waste that have been diverted from landfill for re-use and recycling. Many of the principles that have been established in this project are now being applied across Cofathec's portfolio of refurbishment and fitout projects." 


\section{Department of Environment, Food and Rural Affairs (Defra)}

\section{Lion House Alnwick}

- "Lion House in Alnwick, Northumberland is a multi-award winning, $1600 \mathrm{~m}^{2}$, two storey office building. It replaced an existing building and provides office accommodation for the Department for Environment, Food \& Rural Affairs, (DEFRA). The project, named the Zero Emissions Building Renewing Alnwick (ZEBRA) project, is a flagship ultra low-emissions development which is designed to achieve exemplary standards of sustainability and environmental performance. Throughout the design, construction and occupation processes, the focus has been to minimise environmental impact throughout its lifetime.

- It aimed to exceed an excellent (70\%) BREEAM rating under the Offices 2006 rating scheme and achieved a score of $80.72 \%$ at design stage (the highest BREEAM score in the UK in 2008). The building is currently being assessed under the new BREEAM 2008 scheme at post construction review stage with the goal of achieving the new outstanding rating. This building also aimed to be one of the first new zero carbon office buildings in the country, generating enough energy from carbon free energy sources to exceed the carbon emissions from its own operation. The design enables this by minimising energy usage through the use of natural and passive measures wherever possible and the use of highly energy efficient mechanical systems only where necessary.
- The use of renewable (zero carbon) energy technologies are a key feature in achieving a zero carbon design.

- Low carbon and innovative design features of the building include

- $3 \times 15 \mathrm{~kW}$ wind turbines expected to generate $63,000 \mathrm{kWh} / a n n u m$

- $120 \mathrm{~m}^{2} 15 \mathrm{~kW}$ photovoltaic solar shading arrays (replacing brise-soleil) expected to generate $12,000 \mathrm{kWh} /$ annum

- Biomass heating system to meet $90 \%$ of thermal demands

- Solar thermal hot water generation to meet $50 \%$ of hot water demand

- Naturally ventilated office, enhanced with mechanical displacement ventilation with heat recovery when temperature/air quality requires

- Exposed thermal mass to allow for passive night cooling

- Highly efficient energy recovery systems to minimise primary energy usage

- Direct-indirect, daylight dimming and motion sensing background lighting with boosted task lighting at desks
- Insulation levels which go well beyond the Part L 2006 minimum standards (using sheep's wool insulation)

- Real-time energy display in building reception giving details of the performance of the renewable energy technologies, building energy use and annual $\mathrm{CO}_{2}$ emissions

- Traffic light indicators to inform the users as to how the building should be operated for best efficiency

- Very low potable water usage due to low use fittings and rainwater harvesting

- Materials selected for low embodied energy and carbon (glu-lam frame, sheep's wool insulation, cedar cladding, etc)

- Other sustainability issues covered in detail to maximise BREEAM score.

In addition to the BREEAM excellent rating, Lion House has achieved an A+ Energy Performance Asset Rating (scoring 14, the highest possible achievement and the first of its kind on the Government Estate) In January 2009, the Chartered Institute of Building Services Engineers (CIBSE) named it "New Build Project of the Year" in their Low carbon Awards." 


\section{Travel}

\section{Vehicle and Operator Services Agency (VOSA)}

\section{Jam Busting June}

"Jam Busting June challenges commuters in the Bristol area to choose more sustainable modes of transport for getting to work during the month of June. The challenge is very simple: the more days you travel to work using sustainable transport, the greater the chance you have of winning prizes! 2008 was the 4th year that VOSA has taken part. The competition is run by the local councils and allows individuals, groups and companies to compete against one another. Each journey made during June is recorded via an online travel diary which collates the number of points earned and the amount of $\mathrm{CO}_{2}$ saved. Prizes range from pedometers to brand new bikes. The competition promotes the use of sustainable transport encouraging and rewarding both people who try something new and those who do so already. VOSA's main aim was to get more people involved than ever and to beat our corporate position of last year of 31st place out of more than 240 .

\section{The Barriers}

The main barrier was trying to gain new recruits to join up and take part particularly amongst those who do not normally use sustainable transport in the commute to and from work. There were also time limitations on when the event could be promoted as the website for registration was not up and running until mid-May.

To overcome these barriers, the Sustainable Development Unit (SDU) undertook a campaign to promote the competition. This included sending an email to all staff in the area telling them about the competition with links to useful websites such as to cycle paths and bus timetables etc. A case study was also produced and distributed around the sites in the cafeterias and on notice boards. A free "Doctor Bike" surgery was held at our Berkeley House headquarters in May, ensuring that everybody's bike was safe and in good condition for the challenge. Staff were also encouraged to compete in teams of 4 to increase the element of fun and encourage uptake. 


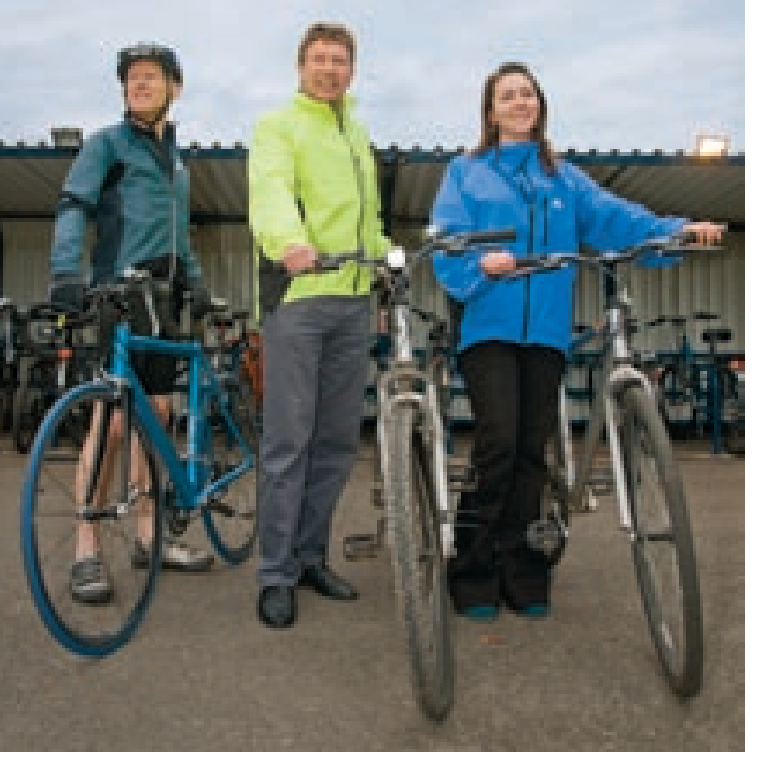

\section{The Outcomes and Benefits}

The competition was a great success. Fourteen extra people signed up taking the total number of VOSA competitors in 2008 to 44 . A massive $1,579 \mathrm{~kg}$ of $\mathrm{CO}_{2}$ was saved and VOSA also managed to beat its corporate position by finishing in $18^{\text {th }}$ place out of 251.

The city-wide approach to promoting the use of sustainable transport helped VOSA to promote and gain easy access to locally focused travel advice and facilities. It also identified more options to help VOSA staff in Bristol choose more sustainable modes of transport.

More action is required to ensure the use of sustainable transport all year round and for the competition to be even more of a success next year. The SDU are planning on running "Doctor Bike" and similar events through the course of the year and are looking into the possibility of providing our own prizes for those who enter Jam Busting June to encourage more staff to try new ways of travelling that can be used all year round."

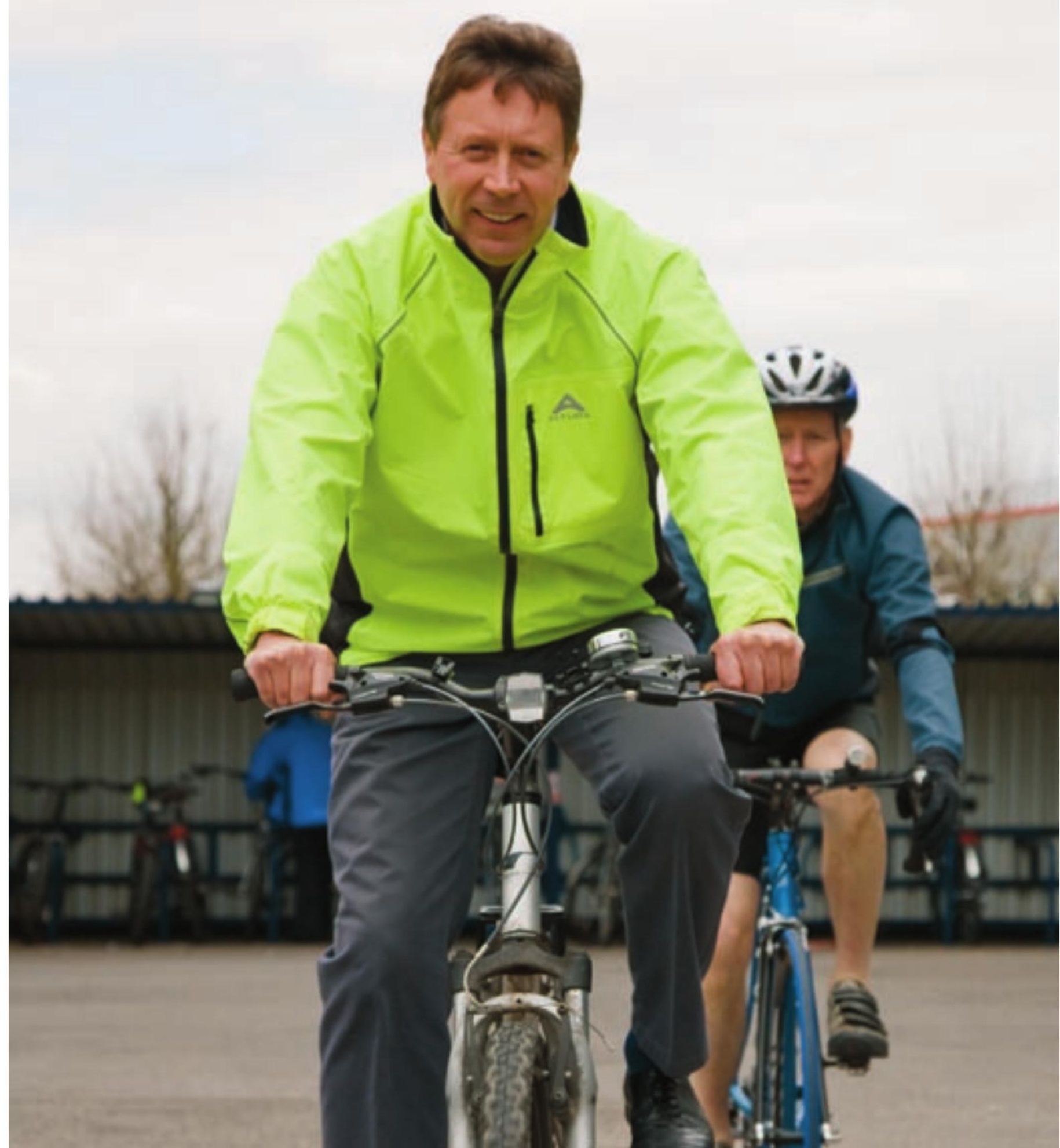




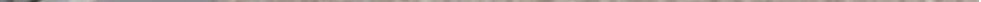

\section{Waste}

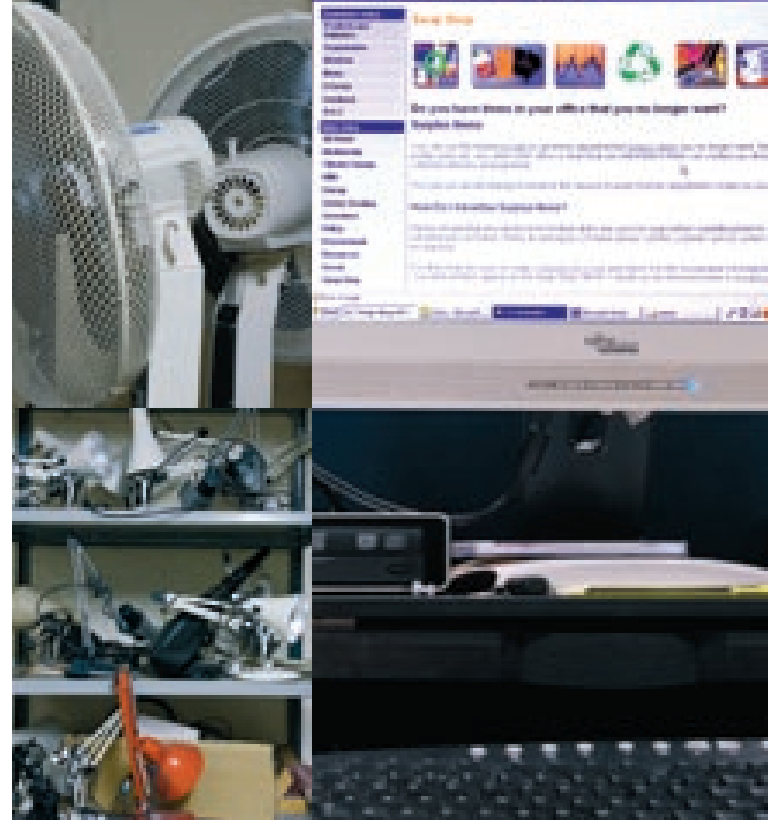

\section{Department for Work and Pensions (DWP)}

\section{Swap Shop}

"Operating over 1132 number of sites, with varying layouts and different in-office administration structures, rationalising this large estate has led to items becoming surplus to original requirements.

The Sustainable Development Team developed the intranet based Swap Shop site (pictured above right) to minimise waste and impact on budgets by ensuring that surplus or unwanted goods were redistributed around the DWP businesses. Other than the small amount of time spent on working up the initial design for the page and the ongoing daily commitment to listing the items, the project has minimal overheads.

An intranet based form is completed and emailed to the SD Team. The advert is checked and styled by the team and then uploaded. Those advertising and those wanting to claim goods deal directly, making their own arrangements to collect, or transport through the Department's courier service. Adverts stay on the system for a month or are removed on request.

The exact weight and number of goods redistributed are difficult to measure due to the diversity, quantity, varying weight and cost of items, ranging from pens to plasma display screens. The fact these items have not gone to landfill and that the need to buy new has been avoided is satisfactory measure enough but we are developing a catch all system to quantify the savings in more detail.

Such has been the success of the scheme that last year wanted pages were introduced. Overall it is an immensely popular scheme and its appeal lies in its simplicity, the feeling of getting something for nothing and not throwing away something which is of use to others. Its popularity and use continues to grow." 


\section{Water}

\section{Vehicle and Operator Services Agency (VOSA)}

\section{Eco-goods vehicle testing station (GVTS)}

"This new build testing station, as part of VOSA's Estate Modernisation Programme, integrates principles and techniques in sustainable construction and environmental management to create a successful, low carbon, low cost business premise. The concept was to design and build a sustainable office block to accompany VOSA's new goods vehicle testing station (GVTS) to serve Bristol and the surrounding area, on a new VOSA site in Avonmouth.

The station and office opened on 7th April 2008 on a full-time operating basis. Both buildings took about a year to construct. vOSA has a dedicated Modernisation Team who work on managing the design construction and finance of all VOSA modernised sites. The site has been developed using

\section{Barriers}

Originally, the design incorporated a wind turbine to be situated on site to increase the sustainability of the premises. However, the planning department of the local council rejected the application due to wildlife concerns. In order to retain the element of renewable energy generation as part of this project, the project team incorporated solar photovoltaic panels into the design instead.

an innovative contracting model - JCT Constructing Excellence (JCT-CE). This is a collaborative contract, unique in the way it engages contractors, consultants and any tier of the supply chain involved in the overall project outcome.

The utility consumption of the site is monitored through the SOGE reporting mechanism and will be used to establish benchmarks for comparisons between GVTSs, to aid monitoring and targeting of initiatives to increase efficiency of consumption. Biodiversity levels are also to be monitored regularly by independent consultants to ensure the protected species on site are thriving in existing and newly created habitats.

\section{Outcomes \& Benefits}

This project adheres to the stringent standards of VOSA's Modernisation Programme: reducing construction waste at site by $50 \%$ compared to conventional construction, recycling is maximised and money is saved in the long term by considering whole life costing. Specifically, this site works in harmony with the surrounding natural environment: it incorporates many features that reduce its environmental impact.

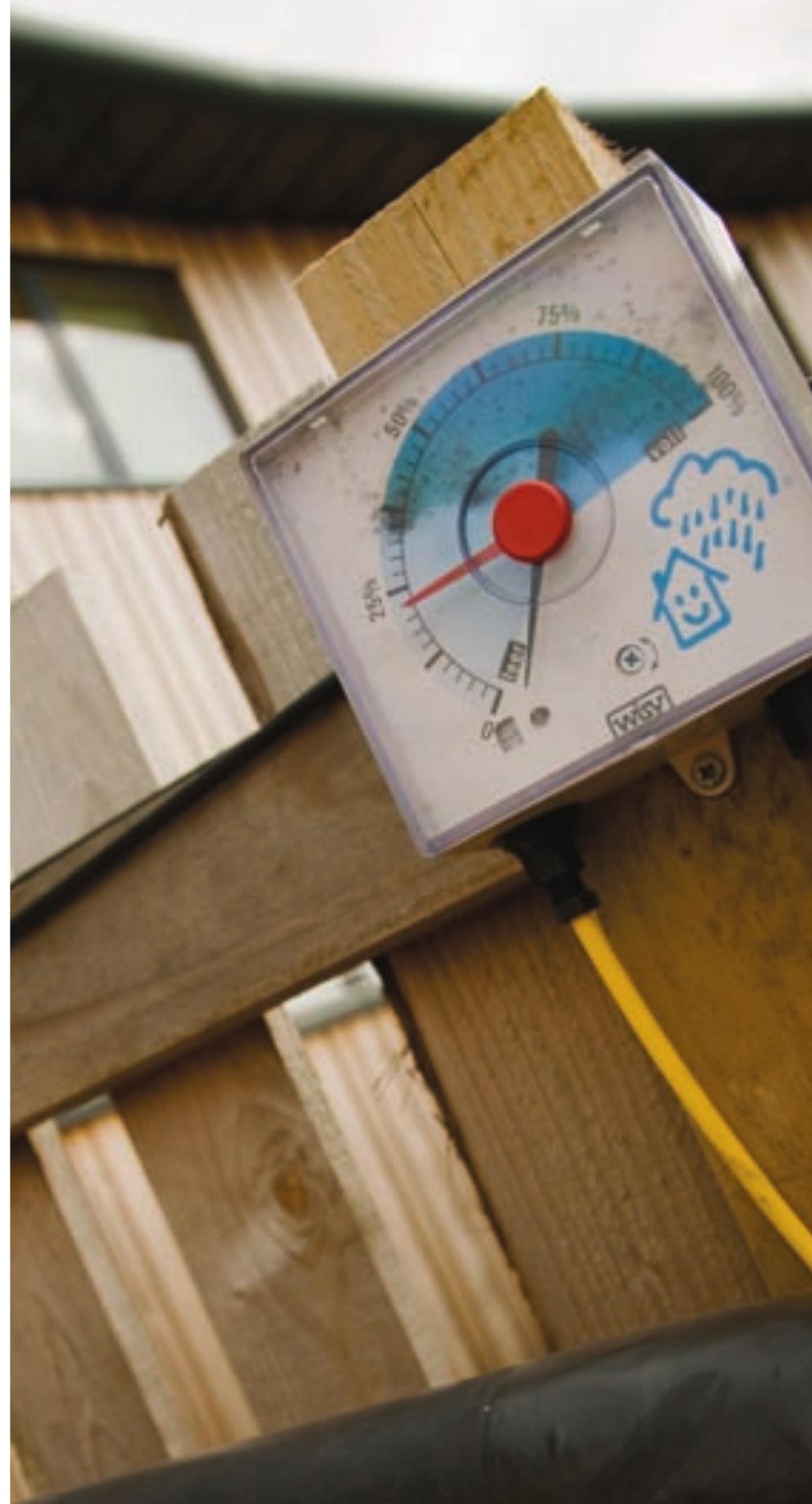


- The office building maximises 'thermal lag' - its high mass means it heats and cools slowly, reducing additional heating or cooling necessary. Passive stack ventilation (pictured above) provides continual air flow through the office.

- Solar photovoltaic (PV) panels installed on the testhall roof generate electricity for use on site - enough to supply the small power and lighting in the office.

- A rainwater-harvesting system (pictured left) installed recycles rainwater, reducing the mains water consumption of the site and burden on discharge processes.
- Habitats rich in biodiversity have been conserved and recreated where necessary to protect the wide range of species inhabiting the site (pictured above)

- Remediation works by VOSA have made this contaminated brownfield site safe for redevelopment.

This particular site is a Constructing Excellence demonstration project and has been visited by local schools who wish to learn about sustainable construction." 


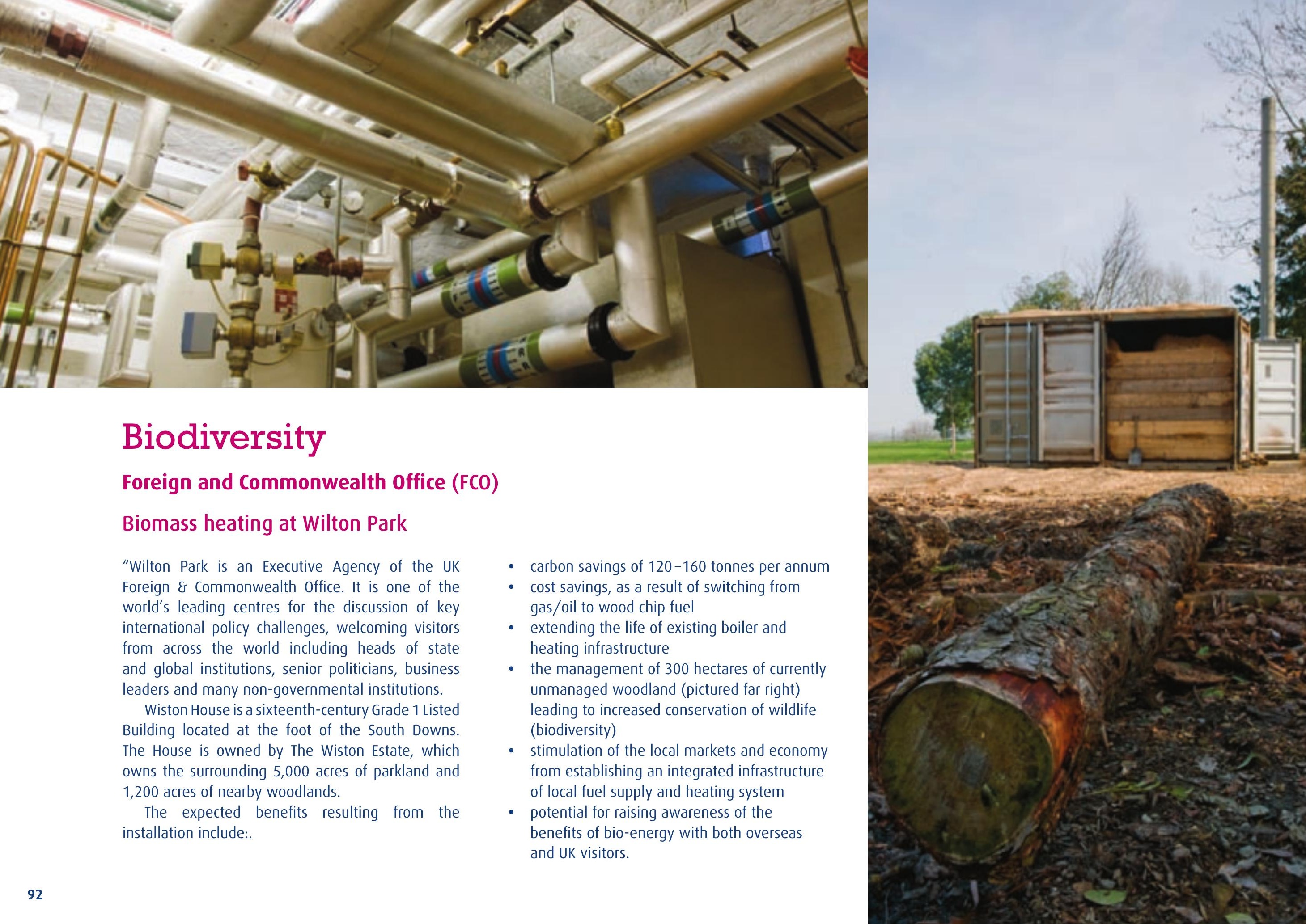




\section{Ministry of Defence (MOD)}

\section{Defence Estates - Biodiversity at Catterick Garrison}

"Catterick Garrison, in North Yorkshire, is the Army's largest base, accommodating approximately an 11,000 military and civilian population. There is currently a $£ 280$ million programme of modernisation and redevelopment at the Garrison with more planned over the next 15 to 20 years. The development will incorporate the principles of sustainable development one of which is to: Protect habitats and species and promote opportunities to enhance and conserve wildlife.

\section{Foxglove Covert Local Nature Reserve}

An area of Willow Carr behind Cambrai Barracks was established as a conservation area in 1992. In April 2001 the area known as Foxglove Covert was declared the first Local Nature Reserve (LNR) on MOD land in the UK and now includes rich wildlife habitat covering an area the size of 38 new Wembley Stadium pitches. The site is managed by representatives from the MOD, Richmondshire District Council, Natural England and volunteers in such a way to retain and enhance the varied habitats but also to allow the local community to enjoy and appreciate it, with a strong emphasis on education at all levels. A purpose-built field centre was constructed in 2002 which provides an excellent and educational base for visitors to the reserve.

\section{New Bat House}

Prior to work commencing on the new sports and leisure facilities at the Garrison an ecology survey was undertaken as part of an Environmental Impact Assessment. The survey identified the presence of bats in the existing library building due for demolition. A licence was obtained from Natural England in order for the existing bat roost to be disturbed, and a suitable replacement home for the bats was required. It was decided that the most appropriate option would be to build a new bat habitat - the bat house. A design was agreed and planning permission was gained for the bat house which was located in a position where other development projects at the Garrison could also have the benefit of a new bat roost if necessary.

\section{Other Biodiversity Solutions at Catterick Garrison include:}

- Retention and enhancement of green areas and corridors for habitat and to allow movements of wildlife throughout the Garrison. The green areas and corridors cover about $30 \%$ of the area of the Garrison.

- Excavations during construction have 45 degree slopes to allow wildlife, including badgers to escape.
- Where possible during construction, trees have been retained. Where trees were removed from the areas to be occupied by buildings then replacement trees have been planted.

- A woodland management plan has been established for the 120ha of woodland at the Garrison." 


\section{Cross-cutting Issues}

\section{Forestry Commission (FC)}

\section{Greenerways programme}

"The Forestry Commission (FC) is the government department responsible for Britain's forests and woodlands. We manage over a million hectares throughout England, Scotland, and Wales, making us the biggest land manager in the UK. We employ over 3000 staff, predominantly in rural locations.

Our 'Greenerways' programme was set up in 2006 to instil a green philosophy to all our business performance. Greenerways promotes an environmental management approach to all our administrative tasks, and places sustainability at the heart of all FC activities. It complements the sustainable management of the forest estate which has been certified under the United Kingdom Woodland Assurance Scheme for many years.

\section{The barriers - meeting the SOGE framework}

The diversity of business interests; geographical spread of the organisation, and rural context, brings unique challenges to the $\mathrm{FC}$ in meeting government targets.

The building stock is ageing, and will require significant investment to achieve high standards of energy efficiency. New builds do not meet BREEAM excellence criteria, as countryside locations cannot meet some requirements of the standard. Despite this, many of our new builds have won awards for sustainability.
With over 600 energy meters, recording was poor, so no measurable baselines existed. Few sites have water meters. There are multiple waste streams with fly tipping and car dumping adding to our business waste.

There has always been a need to travel inherent in our work. Much of this has to be by road, but with air and rail travel needed for managers travelling around the three countries and overseas. Lack of facilities for audio and video conferencing made alternative solutions to travel difficult.

\section{The outcomes and benefits}

Greenerways has changed how we think about delivering the business. It has addressed many of the sustainability challenges within the organisation, and reported under SOGE.

We are now working towards achieving IS014001 in 2010. Our EMS will provide the framework for addressing barriers to progress, specifically data collection, waste and buildings management, travel and procurement. It will also integrate with existing systems for sustainable forest management.

A noteworthy success has been awareness of the environmental impacts of road travel. We began collecting data in 2006 to access our operational and administrative mileage, and the modes of transport favoured. This led to the introduction of an FC travel strategy. We aim to achieve a 5\% carbon reduction from administrative travel each year.
We have reviewed our fleet to reduce engine size and explored dual-fuel vehicles, electric cars, and biodiesel. Cutting the choice of hire cars to favour more efficient options helped our carbon emissions.

We promote cutting back on travel by offering suitable alternatives for meetings. Audioconferencing has proved popular and effective, whilst we are still investigating video-conferencing. When remotely managed meetings are not possible, we have encouraged a programme of holding meetings centrally with good public access links. Main offices are now operating lift share schemes and work patterns have been restructured to reduce travel." 


\section{Defence Estates - Community involvement at Catterick Garrison}

"Catterick Garrison, in North Yorkshire, is the Army's largest base, accommodating approximately an 11,000 military and civilian population. There is currently a $\mathbf{£ 2 8 0}$ million programme of modernisation and redevelopment at the Garrison with more planned over the next $\mathbf{1 5}$ to 20 years. The development will incorporate the principles of sustainable development one of which is to: Promote the MOD as a good neighbour which works with local communities to minimise disturbance and maximise positive social impacts.

\section{Richmond Swale Valley Community Initiative}

The Richmond Swale Valley Community Initiative (RSVCl) is a community group working with the public and private sector to improve the long term prosperity of Richmond and its hinterland. It was formed in 2003 by a merger between the Richmond Partnership and the Richmond Town Centre Forum. DE are represented in the $\mathrm{RSVCl}$ in order to maintain and enhance the relationship between Richmond and the Garrison and allay any concerns of Richmond residents relating to the Garrison development. $\mathrm{DE}$ involvement in the $\mathrm{RSVCl}$ has been highly successful, particularly where it has allowed early involvement and dialogue with the local community regarding future developments at the Garrison and ensuring whenever possible that the needs and opinions of the local population have been considered.
The RSVCl has been critical with regard to the new 7.2ha town centre development especially given the catchment population of around 60,000. The needs of the local community will be catered for by a mixed use scheme, comprising retail, restaurants, cafes, hotel, car parking, public open space, offices, residential and leisure uses all to be designed and constructed in a sustainable way.

\section{Working with Local Schools}

The development of Catterick Garrison is a large project being carried out over a number of years which is for the benefit of the MOD and the local community.

The prime contractor for the project (Carillion Enterprise) visited local schools (ages 7 to 15) to present details of the projects. Pupils and teachers were then invited back to see the construction projects first hand, work placements were also offered to those pupils thinking of pursuing a career in the construction industry.

The site visits and work placements were very well received by the pupils, teachers and project staff. Pupils were given an insight into the opportunities available to them in construction, such as environmental or sustainability managers, as well as the conventional site based jobs. Local schools were made more aware of activities happening around the area and were involved in the activities which help foster relationships between the community and MOD. Safety awareness has also been raised within the local student community, reducing the likelihood of children playing on potentially dangerous construction sites and being aware of additional construction traffic.

\section{Hipswell Lodge}

In a partnership including DE, Carillion, White Rabbit \& Dales Nursery Pre-schools and the Army Welfare Service the Catterick Garrison development team have used their time and resources to provide improvements to the Hipswell Lodge community facility including:

- Construction of planter boxes from recycled pallets for children to work on

- Renovation works to WC

- Construction and marking of new car park

- Shed conversion - installation of windows to make role play areas.

\section{Just the Job}

Around 100 tree trunks were removed from the Catterick Campus 1 project. The tree trunks were donated to the local charity "Just the Job Environmental Enterprises Limited" who provide employment, education and work based training to disadvantaged and special needs people. The tree trunks are processed to provide fuel for off-site biomass boilers." 


\section{Annex C}

\section{Scoring methodology for the Sustainable Development in Government (SDiG) 2008 assessment}

\section{A. Methods of assessment}

The report uses two illustrations of performance assessment: traffic light indicators and overall star ratings. The key findings based on this assessment are drawn out in Chapter 3 - SOGE Framework Performance Assessment - SOGE Targets, Mandated Mechanisms and SPAP Commitments

\section{B. 'Traffic light' indicators of performance}

The scoring framework is outlined in Table C. 1 below. Progress and scoring against each of the SOGE targets is based on four categories:

What constitutes 'excellent', 'good', 'some' or 'no/poor' progress is based on the degree of progress made against the target, considering where a department should be now if the outcomes required are to be achieved by the target date. The scoring methodology is shown in Table C.2. The points awarded for each target area are added together to give an overall percentage of points scored, on which the star rating is based.

\section{Table C.1 Performance traffic light indicators}

\begin{tabular}{|l|l|}
\hline $\begin{array}{l}\text { 'Excellent progress warranting recognition' which could mean } \\
\text { a future target performance level has already been achieved. }\end{array}$ \\
\hline $\begin{array}{l}\text { 'Good progress' which is defined as being on track to hit the target. } \\
\text { 'Some progress' which recognises that some progress has been made, } \\
\text { but is not sufficient to be on track to meet the target. }\end{array}$ \\
\hline $\begin{array}{l}\text { 'No progress or poor progress' where no progress or in our judgement only } \\
\text { slight progress has been made. Red is also used where data was 'not known'. }\end{array}$ \\
\hline Not applicable \\
\hline
\end{tabular}




\section{Table C.2 Core assessment methodology}

\begin{tabular}{|c|c|c|c|c|c|c|c|}
\hline $\begin{array}{l}\stackrel{\mathscr{E}}{E} \\
\stackrel{E}{上}\end{array}$ & Target & $\begin{array}{l}\text { Excellent } \\
\text { progress that } \\
\text { warrants merit } \\
=1.2 \text { points }\end{array}$ & $\begin{array}{l}\text { Very good } \\
\text { progress } \\
=1.1 \text { points }\end{array}$ & $\begin{array}{l}\text { Good progress= } \\
1 \text { point }\end{array}$ & $\begin{array}{l}\text { Some progress } \\
=0.5 \text { points }\end{array}$ & $\begin{array}{l}\text { No progress or } \\
\text { poor progress } \\
=0 \text { points }\end{array}$ & Notes \\
\hline \multirow{4}{*}{ 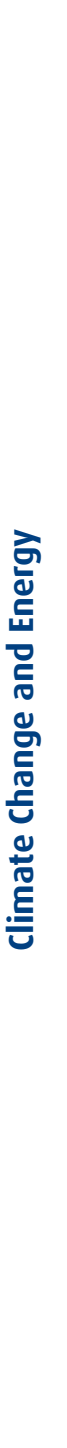 } & $\begin{array}{l}\text { Reduce carbon } \\
\text { emissions by } \\
12.5 \% \text { by } 2010- \\
11 \text {, relative to } \\
1999-00 \text { levels }\end{array}$ & $\begin{array}{l}\text { Carbon emissions } \\
\text { down by } 12.5 \% \\
\text { or more }\end{array}$ & NA & $\begin{array}{l}\text { Carbon emissions } \\
\text { down by } 9.1 \% \text { - } \\
12.4 \%\end{array}$ & $\begin{array}{l}\text { Carbon emissions } \\
\text { down between } \\
0.1 \% \text { and } 9.0 \% \text {. }\end{array}$ & $\begin{array}{l}\text { Carbon emissions } \\
\text { equal or higher } \\
\text { than } 99 / 00 \\
\text { levels }\end{array}$ & $\begin{array}{l}11 \text { years to hit target, } \\
\text { approx } 1.14 \% \text { per } \\
\text { year linear. } 8 \text { years } \\
\text { progressed, so good } \\
\text { performance is } 9.1 \%\end{array}$ \\
\hline & $\begin{array}{l}\text { Reduce carbon } \\
\text { emissions } \\
\text { from road } \\
\text { vehicles used } \\
\text { for Government } \\
\text { administrative } \\
\text { operations by } \\
15 \% \text { by } 2010 / 11 \\
\text { relative to } \\
2005 / 06 \text { levels }\end{array}$ & $\begin{array}{l}\text { Carbon emissions } \\
\text { down by } 15 \% \text { or } \\
\text { more }\end{array}$ & NA & $\begin{array}{l}\text { Carbon emissions } \\
\text { down between } \\
6 \% \text { and } 14.9 \% \text {. }\end{array}$ & $\begin{array}{l}\text { Carbon emissions } \\
\text { down between } \\
0.1 \% \text { and } 5.9 \%\end{array}$ & $\begin{array}{l}\text { Carbon emissions } \\
\text { equal or higher } \\
\text { than } 05 / 06 \\
\text { levels }\end{array}$ & $\begin{array}{l}\text { Linear scale of } \\
\text { progress, } 3 \% \text { per year } \\
\text { up to } 2010 / 11 \text {. } \\
\text { Two years passed for } \\
\text { good performance is } \\
6 \% \text {. }\end{array}$ \\
\hline & $\begin{array}{l}\text { Central } \\
\text { Government's } \\
\text { office estate to } \\
\text { be carbon neutral } \\
\text { by } 2012 \text {. }\end{array}$ & NA & NA & NA & NA & NA & $\begin{array}{l}\text { This is not being } \\
\text { measured this year, } \\
2012 \text { target. This will } \\
\text { be achieved through } \\
\text { the achievement } \\
\text { of other targets } \\
\text { with offsetting of } \\
\text { remainder the last } \\
\text { option. }\end{array}$ \\
\hline & $\begin{array}{l}\text { Departments to } \\
\text { increase their } \\
\text { energy efficiency } \\
\text { per } \mathrm{m}^{2} \text { by } 15 \% \\
\text { by } 2010 \text {, relative } \\
\text { to } 1999 / 00 \\
\text { levels }\end{array}$ & NA & $\begin{array}{l}\text { Energy use per } \\
\mathrm{m}^{2} \text { down by } \\
15 \% \text { or more } \\
\text { compared to } \\
99 / 00 \text { levels }\end{array}$ & $\begin{array}{l}\text { Energy use } \\
\text { per } \mathrm{m}^{2} \text { down } \\
\text { between } 12 \% \\
\text { and } 14.9 \% \\
\text { compared to } \\
\text { 99/00 levels }\end{array}$ & $\begin{array}{l}\text { Energy use } \\
\text { per } \mathrm{m}^{2} \text { down } \\
\text { between } 0.1 \% \\
\text { and } 11.9 \% \\
\text { compared to } \\
99 / 00 \text { levels }\end{array}$ & $\begin{array}{l}\text { Energy use } \\
\text { per m² equal } \\
\text { or higher than } \\
99 / 00 \text { levels }\end{array}$ & $\begin{array}{l}\text { Presuming March } \\
2010.1 .5 \% \text { per year } \\
\text { for } 8 \text { years }=12 \% \text {. }\end{array}$ \\
\hline
\end{tabular}




\begin{tabular}{|c|c|c|c|c|c|c|c|}
\hline 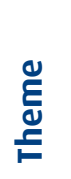 & Target & $\begin{array}{l}\text { Excellent } \\
\text { progress that } \\
\text { warrants merit } \\
=1.2 \text { points }\end{array}$ & $\begin{array}{l}\text { Very good } \\
\text { progress } \\
=1.1 \text { points }\end{array}$ & $\begin{array}{l}\text { Good progress= } \\
1 \text { point }\end{array}$ & $\begin{array}{l}\text { Some progress } \\
=0.5 \text { points }\end{array}$ & $\begin{array}{l}\text { No progress or } \\
\text { poor progress } \\
=0 \text { points }\end{array}$ & Notes \\
\hline \multirow{2}{*}{ 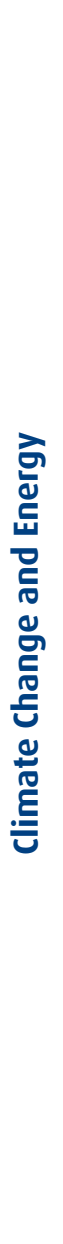 } & $\begin{array}{l}\text { Departments to } \\
\text { source at least } \\
10 \% \text { of electricity } \\
\text { from renewables } \\
\text { (by } 31 \text { March } \\
2008 \text { ). }\end{array}$ & NA & $\begin{array}{l}50 \% \text { or more } \\
\text { of electricity } \\
\text { sourced from } \\
\text { renewable } \\
\text { sources }\end{array}$ & $\begin{array}{l}10 \% \text { or more } \\
\text { of electricity } \\
\text { derived from } \\
\text { renewable } \\
\text { sources }\end{array}$ & NA & $\begin{array}{l}\text { Less than 10\% } \\
\text { of electricity } \\
\text { derived from } \\
\text { renewable } \\
\text { sources }\end{array}$ & $\begin{array}{l}\text { Target date this } \\
\text { year, } 10 \% \text { means } \\
\text { department has hit } \\
\text { target. Additional } \\
\text { credit for } 50 \% \text { or } \\
\text { greater. No points } \\
\text { for not achieving } \\
\text { target. MOD have } \\
\text { been scored based } \\
\text { upon a linear scale of } \\
\text { performance as they } \\
\text { have an extension } \\
\text { until } 2010 \text { to achieve } \\
\text { this target. }\end{array}$ \\
\hline & $\begin{array}{l}\text { Departments to } \\
\text { source at least } \\
15 \% \text { of electricity } \\
\text { from Combined } \\
\text { Heat and Power } \\
\text { (CHP) (by 2010) } \\
\text { except where } \\
100 \% \text { is procured } \\
\text { as renewable } \\
\text { energy. }\end{array}$ & NA & $\begin{array}{l}15 \% \text { of electricity } \\
\text { generated from } \\
\text { CHP (target } \\
\text { achieved) }\end{array}$ & $\begin{array}{l}11.3 \%-14.9 \% \\
\text { of electricity } \\
\text { derived from CHP }\end{array}$ & $\begin{array}{l}5 \%-11.2 \% \\
\text { of electricity } \\
\text { derived from CHP }\end{array}$ & $\begin{array}{l}\text { Less than } 5 \% \\
\text { of electricity } \\
\text { derived from CHP }\end{array}$ & $\begin{array}{l}\text { Target date is defined } \\
\text { as the } 31 \text { st of } \\
\text { March } 2010 \text {. Linear } \\
\text { extrapolation of } \\
\text { progress, so far } 6 \\
\text { out of } 8 \text { years. } \\
\text { The } 5 \% \text { for } 0.5 \text { points } \\
\text { is consistent with } \\
\text { the assessment for } \\
2005 / 06 \text {. Target } \\
\text { is not applicable } \\
\text { where greater than } \\
85 \% \text { is procured as } \\
\text { renewable energy. }\end{array}$ \\
\hline
\end{tabular}




\begin{tabular}{|c|c|c|c|c|c|c|c|}
\hline 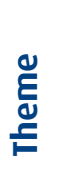 & Target & $\begin{array}{l}\text { Excellent } \\
\text { progress that } \\
\text { warrants merit } \\
=1.2 \text { points }\end{array}$ & $\begin{array}{l}\text { Very good } \\
\text { progress } \\
=1.1 \text { points }\end{array}$ & $\begin{array}{l}\text { Good progress } \\
=1 \text { point }\end{array}$ & $\begin{array}{l}\text { Some progress } \\
=0.5 \text { points }\end{array}$ & $\begin{array}{l}\text { No progress or } \\
\text { poor progress } \\
=0 \text { points }\end{array}$ & Notes \\
\hline \multirow{3}{*}{ 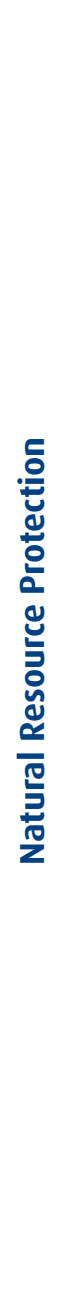 } & $\begin{array}{l}\text { Departments } \\
\text { to meet or } \\
\text { exceed the aim } \\
\text { of having } 95 \% \\
\text { of SSSIs in sole } \\
\text { ownership in } \\
\text { target condition } \\
\text { by } 2010\end{array}$ & $\begin{array}{l}95 \% \text { or more of } \\
\text { SSSIs in target } \\
\text { condition }\end{array}$ & NA & $\begin{array}{l}\text { Between } 68 \% \\
\text { and } 94.9 \% \text { of } \\
\text { SSSIs in target } \\
\text { condition }\end{array}$ & $\begin{array}{l}\text { Between } 50 \% \\
\text { and } 67.9 \% \text { of } \\
\text { SSSIs in target } \\
\text { condition }\end{array}$ & $\begin{array}{l}\text { Less than } 50 \% \\
\text { of SSSIs in } \\
\text { target condition }\end{array}$ & $\begin{array}{l}\text { Not a linear scale as there } \\
\text { is no baseline year. Good } \\
\text { progress determined by } \\
\text { previous framework target of } \\
68 \% \text {. If target has been hit } \\
\text { early a bonus will be applied. } \\
50 \% \text { minimum cut off. }\end{array}$ \\
\hline & $\begin{array}{l}\text { Reduce water } \\
\text { consumption } \\
\text { by } 25 \% \text { on the } \\
\text { office and non- } \\
\text { office estate by } \\
2020 \text {, relative } \\
\text { to } 2004 / 05 \\
\text { levels. }\end{array}$ & $\begin{array}{l}\text { Water } \\
\text { consumption } \\
\text { reduced by } \\
12.5 \% \text { or more } \\
\text { compared to } \\
2004 / 05 \text { levels }\end{array}$ & NA & $\begin{array}{l}\text { Water } \\
\text { consumption } \\
\text { reduced } \\
\text { between } 5 \% \\
\text { and } 12.4 \% \\
\text { compared to } \\
2004 / 05 \text { levels }\end{array}$ & $\begin{array}{l}\text { Water } \\
\text { consumption } \\
\text { reduced } \\
\text { between } 0.1 \% \\
\text { and } 4.9 \% \\
\text { compared to } \\
2004 / 05 \text { levels }\end{array}$ & $\begin{array}{l}\text { Water use equal } \\
\text { or higher than } \\
2004 / 05 \text { levels }\end{array}$ & $\begin{array}{l}\text { Target date defined as } \\
\text { March } 2020 \text {. Indication of } \\
\text { progress determined by linear } \\
\text { extrapolation for } 2007 / 08 \\
\text { compared to } 2004 / 0515 \\
\text { years to hit target, } 3 \text { years } \\
\text { out of } 15=5 \% \text {. Any overall } \\
\text { reduction is rewarded with } \\
\text { half a point if target has been } \\
\text { hit. Excellent progress defined } \\
\text { as being half way towards } \\
2020 \text { target }(12.5 \%) \text {. }\end{array}$ \\
\hline & $\begin{array}{l}\text { Reduce water } \\
\text { consumption } \\
\text { to an average } \\
\text { of } 3 \mathrm{~m}^{3} \text { per } \\
\text { person/year for } \\
\text { all new office } \\
\text { builds or major } \\
\text { refurbishment } \\
\text { projects }\end{array}$ & NA & NA & $\begin{array}{l}\text { All new builds } \\
\text { or major } \\
\text { refurbishments } \\
\text { achieving } \\
\text { consumption of } \\
3 \mathrm{~m}^{3}\end{array}$ & NA & $\begin{array}{l}\text { All new builds } \\
\text { or major } \\
\text { refurbishments } \\
\text { not achieving } \\
\text { consumption of } \\
3 \mathrm{~m}^{3}\end{array}$ & $\begin{array}{l}\text { Straight forward hit or miss } \\
\text { target. Only applies to new } \\
\text { builds where } 2007 / 08 \text { is the } \\
\text { first year of occupancy. }\end{array}$ \\
\hline
\end{tabular}




\begin{tabular}{|c|c|c|c|c|c|c|c|}
\hline$\underset{\mathscr{E}}{\stackrel{\mathscr{E}}{E}}$ & Target & $\begin{array}{l}\text { Excellent } \\
\text { progress that } \\
\text { warrants merit } \\
=1.2 \text { points }\end{array}$ & $\begin{array}{l}\text { Very good } \\
\text { progress } \\
=1.1 \text { points }\end{array}$ & $\begin{array}{l}\text { Good progress } \\
=1 \text { point }\end{array}$ & $\begin{array}{l}\text { Some progress } \\
=0.5 \text { points }\end{array}$ & $\begin{array}{l}\text { No progress or } \\
\text { poor progress } \\
=0 \text { points }\end{array}$ & Notes \\
\hline \multirow{2}{*}{ 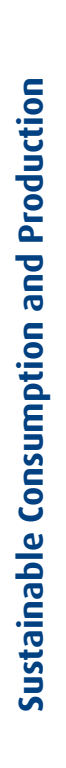 } & $\begin{array}{l}\text { Departments } \\
\text { to reduce their } \\
\text { waste arisings } \\
\text { by } 5 \% \text { by } 2010 \text {, } \\
\text { relative to } \\
2004 / 05 \text { levels }\end{array}$ & NA & $\begin{array}{l}\text { Waste arisings } \\
\text { down by } 5 \% \text { or } \\
\text { more compared } \\
\text { to } 04 / 05 \text { levels }\end{array}$ & $\begin{array}{l}\text { Waste arisings } \\
\text { down between } \\
3 \% \text { and } 4.9 \% \\
\text { compared to } \\
04 / 05 \text { levels }\end{array}$ & $\begin{array}{l}\text { Waste arisings } \\
\text { down between } \\
0.1 \% \text { and } 2.9 \% \\
\text { compared to } \\
04 / 05 \text { levels }\end{array}$ & $\begin{array}{l}\text { Waste arisings } \\
\text { equal or higher } \\
\text { than } 04 / 05 \\
\text { levels }\end{array}$ & $\begin{array}{l}\text { Target date defined as the } \\
31 \text { st March } 2010 \text {. Linear } \\
\text { scale of progress, } 1 \% \text { per } \\
\text { year since } 2004 / 05 \text {. Any } \\
\text { overall reduction in waste is } \\
\text { rewarded with half a point. } \\
\text { If target has been hit early a } \\
\text { bonus will be applied. }\end{array}$ \\
\hline & $\begin{array}{l}\text { Departments to } \\
\text { increase their } \\
\text { recycling figures } \\
\text { to } 40 \% \text { of their } \\
\text { waste arisings } \\
\text { by } 2010\end{array}$ & NA & $\begin{array}{l}\text { Recycling rate } \\
\text { of } 40 \% \text { or more }\end{array}$ & $\begin{array}{l}\text { Recycling rate } \\
\text { of } 30-39.9 \%\end{array}$ & $\begin{array}{l}\text { Recycling rate } \\
\text { of } 20-29.9 \%\end{array}$ & $\begin{array}{l}\text { Recycling rate } \\
\text { of less than } \\
19.9 \%\end{array}$ & $\begin{array}{l}\text { Not a linear scale as there is } \\
\text { no baseline year. Category } \\
\text { boundaries determined by } \\
\text { judgement reflecting on } \\
\text { last years performance and } \\
\text { understanding of what should } \\
\text { be achievable. If target has } \\
\text { been hit early a bonus will be } \\
\text { applied. }\end{array}$ \\
\hline
\end{tabular}

One target, the reversal of the upward trend in carbon emissions, has not been assessed as it is no longer applicable. Additional bonus points, aside from those offered for 'excellent progress', are available for good coverage, including that of any Executive Agencies, and for external verification of data as shown in Table C.3. These complement the performance assessment by recognising the importance of coverage in line with government's requirements. The verification bonus is available to encourage better data quality.
Table C.3 Bonus points

\begin{tabular}{|l|l|l|}
\hline \multicolumn{3}{|c|}{ Bonus points } \\
\hline $\begin{array}{l}\text { Executive } \\
\text { Agency's } \\
\text { coverage }\end{array}$ & $100 \%$ coverage of EAs & $\begin{array}{l}0.25 \text { point bonus if } \\
\text { reporting 100\% of EAs }\end{array}$ \\
\hline Verification & $\begin{array}{l}\text { Independent } \\
\text { verification of all data }\end{array}$ & 1 point bonus \\
\hline
\end{tabular}




\section{C. 'Star Rating' of performance}

The SOGE Performance 'Star Rating' indicates the progress made by departments against all 14 SOGE performance

targets. It is based on the overall percentage of available target points achieved, as detailed in Table C.4.

\section{Table C.4 Star rating scoring thresholds}

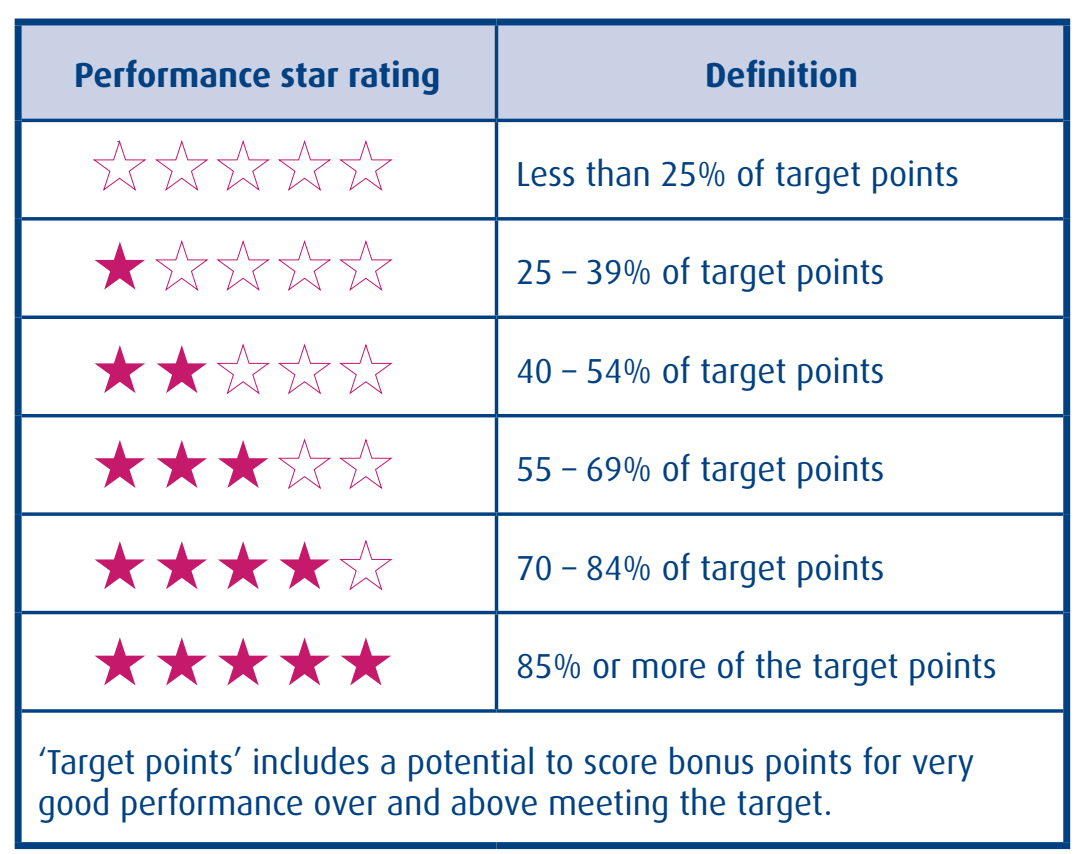

\section{Table C.5 Mechanisms - Traffic light indicators}

\begin{tabular}{|l|l|}
\hline & Mechanism is fully achieved \\
\hline & Mechanism is partially achieved \\
\hline & Mechanism has not been achieved \\
\hline & Not applicable \\
\hline
\end{tabular}

\section{Traffic light indicators for mechanisms to deliver sustainability}

In addition to the key 'outcome driven' SOGE targets, there are a number of mechanisms and supporting processes which the UK government has mandated departments to implement in order to support delivery of the sustainable operations targets. The SDC has assessed the extent to which departments are utilising these mechanisms, to gauge compliance with government requirements, but more importantly to establish whether departments are using the tools they have at their disposal to enable them to achieve future performance improvements.

The scoring framework is outlined in Table C.5. Progress and scoring against each of the mechanisms/supporting processes is based on three categories shown in Table C.6. 
Table C.6 Mechanisms scoring methodology

\begin{tabular}{|c|c|c|c|c|c|}
\hline Theme & Target or Driver & $\begin{array}{l}\text { Good progress } \\
=1 \text { point }\end{array}$ & $\begin{array}{l}\text { Some progress } \\
=0.5 \text { points }\end{array}$ & $\begin{array}{l}\text { No progress or poor } \\
\text { progress }=0 \text { points }\end{array}$ & Notes \\
\hline $\begin{array}{l}\text { Building } \\
\text { Research } \\
\text { Establishment } \\
\text { Environmental } \\
\text { Assessment } \\
\text { Methodology } \\
\text { (BREEAM) }\end{array}$ & $\begin{array}{l}\text { Application of BREEAM } \\
\text { 'excellent' standards } \\
\text { or equivalent to } \\
\text { all new buildings, } \\
\text { and 'very good' or } \\
\text { 'excellent' for major } \\
\text { refurbishments. }\end{array}$ & $\begin{array}{l}100 \% \text { of projects } \\
\text { achieving appropriate } \\
\text { BREEAM standard }\end{array}$ & $\begin{array}{l}80-99 \% \text { of projects } \\
\text { achieving appropriate } \\
\text { BREEAM standard }\end{array}$ & $\begin{array}{l}\text { Less than } 80 \% \text { of } \\
\text { projects achieving } \\
\text { appropriate BREEAM } \\
\text { standard }\end{array}$ & $\begin{array}{l}\text { These percentage thresholds are } \\
\text { consistent with those used for } \\
\text { the comparable target last year. }\end{array}$ \\
\hline $\begin{array}{l}\text { Sustainability } \\
\text { Appraisal }\end{array}$ & $\begin{array}{l}\text { Conduct sustainability } \\
\text { appraisals of all office } \\
\text { relocations }\end{array}$ & $\begin{array}{l}100 \% \text { of projects } \\
\text { with sustainability } \\
\text { appraisals conducted }\end{array}$ & $\begin{array}{l}80-99 \% \text { of projects } \\
\text { with sustainability } \\
\text { appraisals conducted }\end{array}$ & $\begin{array}{l}\text { Less than } 80 \% \\
\text { of projects with } \\
\text { sustainability } \\
\text { appraisals conducted }\end{array}$ & $\begin{array}{l}\text { These percentage thresholds are } \\
\text { consistent with the approach for } \\
\text { BREEAM assessments for o ffice } \\
\text { relocations. }\end{array}$ \\
\hline Carbon Trust & $\begin{array}{l}\text { Adopt the Carbon Trust } \\
\text { Carbon Management } \\
\text { Programme or Energy } \\
\text { Efficiency Programme }\end{array}$ & $\begin{array}{l}\text { Adopted Carbon Trust } \\
\text { CMP or EEP with broad } \\
\text { coverage }\end{array}$ & $\begin{array}{l}\text { Adopted CT CMP or EEP } \\
\text { with limited coverage, } \\
\text { and/or a commitment } \\
\text { to broadly adopt } \\
\text { programme in the } \\
\text { near future. }\end{array}$ & $\begin{array}{l}\text { Poor coverage or no } \\
\text { programme }\end{array}$ & $\begin{array}{l}\text { This is a subjective judgement } \\
\text { based largely upon information } \\
\text { provided by departments in } \\
\text { response to contextual questions. } \\
\text { In general, broad coverage is } \\
\text { defined as the vast majority or all } \\
\text { of the estate. Limited coverage } \\
\text { may be just one building (e.g. } \\
\text { HQ) or one part of department } \\
\text { with clear omissions. }\end{array}$ \\
\hline
\end{tabular}




\begin{tabular}{|c|c|c|c|c|c|}
\hline Theme & Target or Driver & $\begin{array}{l}\text { "Good progress" } \\
=1 \text { point }\end{array}$ & $\begin{array}{l}\text { "Some progress" } \\
=0.5 \text { points }\end{array}$ & $\begin{array}{l}\text { "No progress or poor } \\
\text { progress" = } 0 \text { points }\end{array}$ & Notes \\
\hline $\begin{array}{l}\text { Environmental } \\
\text { Management } \\
\text { Systems (EMS) }\end{array}$ & $\begin{array}{l}\text { Departments to work } \\
\text { towards an accredited } \\
\text { certified EMS i.e. } \\
\text { IS014001 or EMSAS. }\end{array}$ & $\begin{array}{l}80-100 \% \text { staff or } \\
\text { sites covered by EMS }\end{array}$ & $\begin{array}{l}50-79 \% \text { staff or sites } \\
\text { covered by EMS }\end{array}$ & $\begin{array}{l}\text { Less than } 50 \% \text { staff or } \\
\text { sites covered by EMS }\end{array}$ & $\begin{array}{l}\text { The wording of this target is } \\
\text { slightly different to previous } \\
\text { years. As such, a sliding scale } \\
\text { approach has been adopted to } \\
\text { reflect this. }\end{array}$ \\
\hline $\begin{array}{l}\text { Permanent } \\
\text { Secretary (PUS) } \\
\text { Sustainability } \\
\text { Objectives }\end{array}$ & $\begin{array}{l}\text { Permanent Secretaries } \\
\text { are accountable for } \\
\text { the department's } \\
\text { overall progress. } \\
\text { Therefore they should } \\
\text { have sustainability } \\
\text { integrated into their } \\
\text { operating objectives. } \\
\text { Source: SDiG } 2006 \\
\text { and SPAP. }\end{array}$ & $\begin{array}{l}\text { PUS has sustainability } \\
\text { written in performance } \\
\text { agreement / contract }\end{array}$ & $\begin{array}{l}\text { NA - Red or Green } \\
\text { score only }\end{array}$ & $\begin{array}{l}\text { PUS does not have } \\
\text { sustainability written } \\
\text { into performance } \\
\text { agreement/contracts }\end{array}$ & $\begin{array}{l}\text { This was a key recommendation } \\
\text { from last years Sustainable } \\
\text { Development in Government } \\
2006 \text { report, and is important } \\
\text { for the achievement of SPAP } \\
\text { mandate elements now and in } \\
\text { the future. While this mechanism } \\
\text { is a yes or no question for } \\
\text { departments, the SDC has } \\
\text { made the assessment that this } \\
\text { mechanism has been partially } \\
\text { achieved across government. }\end{array}$ \\
\hline $\begin{array}{l}\text { Sustainable } \\
\text { Development } \\
\text { Action Plans } \\
\text { (SDAPs) }\end{array}$ & $\begin{array}{l}\text { Self assessment } \\
\text { rating on the extent } \\
\text { to which sustainable } \\
\text { development is } \\
\text { embedded in the } \\
\text { organisation's } \\
\text { operations. }\end{array}$ & $\begin{array}{l}\text { Rating of 'On Course' } \\
\text { or 'Fully Integrated' }\end{array}$ & $\begin{array}{l}\text { Rating of 'Some } \\
\text { Progress' }\end{array}$ & Rating of 'Starting Out' & $\begin{array}{l}\text { Departments are required } \\
\text { to develop and implement } \\
\text { a Sustainable Development } \\
\text { Action Plan (SDAP). Progress } \\
\text { against SDAPs was reported } \\
\text { by departments and a self } \\
\text { assessment rating of how well } \\
\text { sustainable development has } \\
\text { been embedded into operations } \\
\text { was provided. }\end{array}$ \\
\hline
\end{tabular}




\section{E. Mechanisms star rating}

The overall performance of departments, in terms of the extent to which they are using the mandated mechanisms and achieving any standards required, is illustrated by the star ratings in Table C.7.

Table C.7 Mechanisms scoring methodology

\begin{tabular}{|c|c|}
\hline Performance star rating & Definition \\
\hline$\hat{\omega} \hat{\imath}$ & Less than $25 \%$ of target points \\
\hline$\star \boldsymbol{\lambda}$ & $25-39 \%$ of target points \\
\hline 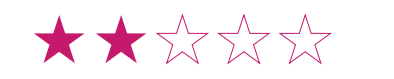 & $40-54 \%$ of target points \\
\hline$\hat{x} \boldsymbol{x} \hat{\boldsymbol{t}} \vec{\psi}$ & $55-69 \%$ of target points \\
\hline 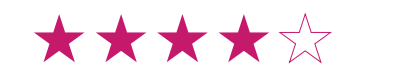 & $70-84 \%$ of target points \\
\hline $\boldsymbol{t} \boldsymbol{t}$ & $85 \%$ or more of the target points \\
\hline
\end{tabular}

\section{F. Traffic light indicators for Sustainable Procurement Action Plan (SPAP) commitments}

The SPAP is government's action plan for embedding sustainability in its procurement practices. The commitments cover leadership and accountability on sustainable procurement; budgeting and accounting practice; building capacity; raising standards; and supplier engagement.

The scoring framework is outlined in Table C.8. Progress and scoring against each of the SPAP commitments is based on three categories shown in Table C.9.
Table C.8 SPAP Commitments - Traffic light indicators

\begin{tabular}{|l|l|}
\hline & Commitment is fully achieved \\
\hline & Commitment is partially achieved \\
\hline & Commitment has not been achieved \\
\hline & Not applicable \\
\hline
\end{tabular}


Table C.9 Mechanisms scoring methodology

\begin{tabular}{|c|c|c|c|c|c|c|}
\hline & Target & Scope & $\begin{array}{l}\text { Good progress } \\
=1 \text { point }\end{array}$ & $\begin{array}{l}\text { Some progress } \\
=0.5 \text { points }\end{array}$ & $\begin{array}{l}\text { No progress } \\
\text { or poor progress } \\
=0 \text { points }\end{array}$ & Notes \\
\hline & $\begin{array}{l}\text { Permanent secretary(ies) has } \\
\text { the SOGE targets and SPAP } \\
\text { commitments incorporated into their } \\
\text { personal performance objectives }\end{array}$ & All Dept & Yes & $\begin{array}{l}\text { NA - Red or Green } \\
\text { score only }\end{array}$ & No & \\
\hline & $\begin{array}{l}\text { Staff with operations and/ } \\
\text { or procurement responsibilities } \\
\text { have the sustainable operations } \\
\text { targets and/or SPAP commitments } \\
\text { incorporated into their personal } \\
\text { performance objectives }\end{array}$ & Core dept only & $100 \%$ staff & $\begin{array}{l}\text { NA - Red or Green } \\
\text { score only }\end{array}$ & $\begin{array}{l}\text { Less than 100\% } \\
\text { staff }\end{array}$ & \\
\hline & $\begin{array}{l}\text { Department's Sustainable } \\
\text { Development Action Plan (SDAP) is } \\
\text { delivering procurement actions }\end{array}$ & Core dept only & Yes & $\begin{array}{l}\text { NA - Red or Green } \\
\text { score only }\end{array}$ & No & \\
\hline \multirow[b]{2}{*}{$\frac{n}{\frac{n}{3}}$} & $\begin{array}{l}\text { Including clauses for Quick Wins/ } \\
\text { extended mandatory product } \\
\text { standards (for all relevant contracts } \\
\text { - new and existing): }\end{array}$ & Core dept only & Yes & $\begin{array}{l}\text { NA - Red or Green } \\
\text { score only }\end{array}$ & No/NK & \\
\hline & $\begin{array}{l}\text { Removing offers that fall below } \\
\text { Quick Wins/extended mandatory } \\
\text { product standards from framework } \\
\text { agreements (where permissible } \\
\text { under existing contract terms)." }\end{array}$ & Core dept only & Yes & $\begin{array}{l}\text { NA - Red or Green } \\
\text { score only }\end{array}$ & $\begin{array}{l}\text { No/NK } \\
\text { Note: This is } \\
\text { related to previous } \\
\text { question. If all } \\
\text { contracts include } \\
\text { Quick Wins then } \\
\text { there are none } \\
\text { to be removed, } \\
\text { therefore } \\
\text { considered to } \\
\text { be NA. }\end{array}$ & $\begin{array}{l}\text { "Maximum available } \\
\text { is } 1 \text { point for both } \\
\text { of these questions. } \\
\text { However application of } \\
\text { this score is subjective } \\
\text { and although generally } \\
\text { follows this method, } \\
\text { any context provided } \\
\text { by department has } \\
\text { been considered and } \\
\text { reflected in the scores. }\end{array}$ \\
\hline
\end{tabular}




\begin{tabular}{|c|c|c|c|c|c|}
\hline Target & Scope & $\begin{array}{l}\text { Good progress } \\
=1 \text { point }\end{array}$ & $\begin{array}{l}\text { Some progress } \\
=0.5 \text { points }\end{array}$ & $\begin{array}{l}\text { No progress or } \\
\text { poor progress } \\
=0 \text { points }\end{array}$ & Notes \\
\hline $\begin{array}{l}\text { Engagement with key suppliers } \\
\text { on sustainable development, the } \\
\text { sustainable operations targets } \\
\text { and the SPAP commitments }\end{array}$ & Core dept only. & Yes & $\begin{array}{l}\text { NA - Red or } \\
\text { Green score } \\
\text { only }\end{array}$ & No & \\
\hline $\begin{array}{l}\text { Use of the Sustainable } \\
\text { Procurement Task Force Flexible } \\
\text { Framework }\end{array}$ & Core dept only. & $\begin{array}{l}\text { Progress to } \\
\text { Level } 2 \text { 'Embed' } \\
\text { across all five } \\
\text { areas }\end{array}$ & $\begin{array}{l}\text { Progress to } \\
\text { Level } 1 \\
\text { 'Embed' across } \\
\text { all five areas }\end{array}$ & $\begin{array}{l}\text { Progress to } \\
\text { Level } 1 \text { 'Embed' } \\
\text { in less than } 5 \\
\text { areas }\end{array}$ & $\begin{array}{l}\text { Last year's approach follows the } \\
\text { sustainable procurement task force } \\
\text { recommendation that departments } \\
\text { reach level one or above across the } \\
\text { five themes by April } 2007 \text {. Some } \\
\text { progress is subjectively set for three } \\
\text { or four themes. }\end{array}$ \\
\hline
\end{tabular}

\section{G. SPAP commitments star rating}

The overall performance of departments, in terms of the extent to which they are achieving the SPAP commitments and achieving any standards required, is illustrated by the star ratings in Table C.10.
Table C.10 SPAP commitments scoring methodology

\begin{tabular}{|c|c|}
\hline Performance star rating & Definition \\
\hline$\hat{w} \hat{\psi} \hat{w}$ & Less than $25 \%$ of target points \\
\hline $\boldsymbol{x} \hat{\psi}$ & $25-39 \%$ of target points \\
\hline$\hat{\boldsymbol{x}} \boldsymbol{\wedge} \hat{\psi} \hat{\psi} \hat{\psi}$ & $40-54 \%$ of target points \\
\hline 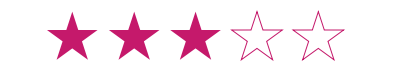 & $55-69 \%$ of target points \\
\hline 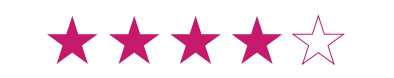 & $70-84 \%$ of target points \\
\hline 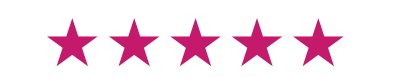 & $85 \%$ or more of the target points \\
\hline
\end{tabular}




\section{Annex D}

\section{Assumptions relating to the recommendation for the potential of self-generated renewables on the government estate}

The recommendations from the Carbon Thematic Area Analysis, Chapter 2 looked at the potential for two types of renewable energy; wind turbine and photovoltaics (PV). The assumptions used to explore the potential for applying these technologies to the government estate are:

\section{Wind}

- Figures taken from the Department for Business, Enterprise and Regulatory Reform (BERR) report, The growth potential for onsite renewable electricity generation in the non domestic sector in England, Scotland and Wales $^{30}$

- Cost figures taken at 2010 price estimates

- BERR estimates total capacity from onsite wind turbines in connection with the UK nondomestic stock at $13 \mathrm{GW}$ with a potential to generate $>16$ TWh per year

- SDC have assumed the UK government estate can generate $10 \%$ of $13 \mathrm{GW}=1330 \mathrm{MW}$ of the BERR projections for the total non domestic sector in the UK

- BERR estimates that of the total capacity for wind 31\% will come from small, $23 \%$ from medium and 46\% from large turbines
- Annual yield in GWh assumes load factors in line with BERR and the British Wind Energy Association (BWEA) of 15\% for small, 30\% for medium and large turbines

- Solar technologies are part of British Gas 2009 estimates, and each kWh produced onsite offsets $0.568 \mathrm{kgCO}$

- Costings are based on installed cost per kW. Payback periods will be significantly impacted by policy choices around Renewable obligation Certificates (ROCs) and feed-in tariffs

- Costing for technology are expected to decrease by $2 \%$ per year but may be countered in the short time by increasing rates for labour due to skill shortages. 


\section{Photovoltaics}

- Figures taken from the Department for Business, Enterprise and Regulatory Reform (BERR) report, The growth potential for onsite renewable electricity generation in the non domestic sector in England, Scotland and Wales $^{31}$

- Cost figures taken at 2010 price estimates

- Figures refer to an average across medium (10-100kW) and large (>100kW) PV systems

- SDC have assumed the UK government estate can generate $1 \%$ of the non economically constrained potential for PV in the non domestic sector, i.e. $1 \%$ of $33 \mathrm{GW}=330 \mathrm{MW}$

- BERR estimates PV produces 850 kWh/kWp/ year for UK installations

- $\quad$ BERR costing for PV for 2010 given as $£ 3,408$ per kW installed

- Solar technologies are part of British Gas 2009 estimates, and each kWh produced onsite offsets $0.568 \mathrm{kgCO}$

- Costings are based on installed cost per kW. Payback periods will be significantly impacted by policy choices around Renewable obligation Certificates (ROCs) and feed-in tariffs

- BERR estimates cost for technology to drop 5-7\% annually but his may be countered in the short term by increasing rates of labour due to skill shortages. 


\section{Endnotes}

1 HM Government, Securing the Future - Delivering the UK Sustainable Development Strategy, March 2005

2 The SDC has a formal role as the UK Government's sustainable development watchdog, reporting to the Prime Minister. In Northern Ireland, Scotland and Wales the SDC's role as the government's advisor on sustainable development is being agreed separately, with Memorandums of Understanding (MoUs) being developed between the SDC and each of the respective devolved governments.

3 www.defra.gov.uk/sustainable/government/gov/ estates/index.htm

4 ibid.

5 Ibid.

6 SOGE Framework - www.defra.gov.uk/sustainable/ government/gov/estates/targets.htm

7 The priority areas covered are climate change and energy, sustainable consumption and production, and natural resource protection. The fourth priority area, sustainable communities, is not covered by the SOGE targets and therefore is not discussed in the SDiG Report. Refer to Securing the Future for more detail on the priority areas for immediate action.

8 In 2006 government developed the new framework for assessing the sustainability of its operations, the SOGE framework, which replaced the 2002 SDGE framework.

9 BRE Environmental Assessment Method: www.breeam.org

10 Tyndall Centre for Climate Change Research: www.tyndall.ac.uk

11 P. 28, Sustainable Development in Government (SDiG) 2007, Sustainable Development Commission, March 2007.

12 The Climate Change Act has committed the UK to reducing its carbon emissions by $80 \%$ by 2050 . Budget 2008 announced the government's ambition that new public sector non-domestic buildings would be zero carbon from 2018, and other new nondomestic buildings would be zero carbon from 2019.
13 For further information on the scopes (or operational boundaries) of a carbon footprint, please see: www. ghgprotocol.org/files/ghg-protocol-revised.pdf

14 www.salixfinance.co.uk/thecompany.htm

15 For details on the assumption made in calculating the figures in Table 1, please see Annex D.

16 www.decc.gov.uk/en/content/cms/consultations/ open/carbon_neutrality/carbon_neutrality.aspx

17 Source: Defra metrics

18 As an indication on the impact of ICT in data centres, please see: http://ec.europa.eu/information_ society/activities/sustainable_growth/docs/ com 2008241 i en.pd

19 www.communities.gov.uk/planningandbuilding/ theenvironment/energyperformance/ publiccommercialbuildings/displayenergycertificates/

20 A definition of Good Quality CHP can be found at the CHP Quality Assurance programme site: https:// www.chpqa.com/guidance notes/GUIDANCE NOTE_10.pdf

21 P. 7, Cabinet Office, Greening Government ICT: Efficient, Sustainable, Responsible, July 2008.

22 www.energysavingtrust.org.uk/business/Business/ Transport-in-business

23 SDiG 08 data collected from departments indicate a government fleet size of 23,556 vehicles. As a proxy for ultra-low carbon vehicles, we have used the 2009 Ford Fiesta ECOnetic, which the government's Act on $\mathrm{CO}_{2}$ website lists as the most fuel efficient new car (www.direct.gov.uk/actonCO2) at $98 \mathrm{gCO} / \mathrm{km}$. If $100 \%$ replacement is assumed, and using the current price of the Fiesta ECOnetic of $£ 12 \mathrm{~K}$ as a per unit estimate, the cost of such a programme would be $£ 283 \mathrm{~m}$.

24 Defra's Water Strategy, 2007

25 Figures are based on discussions with water experts, and very roughly use $£ 0.50$ to $£ 1$ per person relative to the intensity of water usage at each site e.g. offices at low end of the spectrum compared to hospitals and prisons at the high end.
26 The SOGE Performance 'Star Rating' indicates the progress made by departments against the SOGE performance targets. It is based on the overall percentage of available target points achieved as allocated by scoring thresholds, outlined in Table 2 .

27 The mechanisms star rating indicates the extent to which departments are utilising these tools and is a gauge of compliance with government requirements as well as establishing whether departments are using the tools at their disposal to further improve performance. It is based on the overall percentage of available target points achieved as allocated by scoring thresholds, outlined in Table 2.

28 The sustainable development performance of the scottish Government, including consideration of its own operational performance, has been assessed and reported by the SDC in Sustainable Development: A review of progress by the Scottish Government, SDC, November 2008.

29 Climate change and energy, sustainable consumption and production, and natural resource protection. The fourth priority area, sustainable communities, is not covered by the SOGE targets and therefore is not discussed in the SDiG report. Refer to Securing the Future for more detail on the priority areas for immediate action.

30 The growth potential for on-site renewable electricity generation in the non domestic sector in England, scotland and Woles, BERR, 2008. www.berr.gov.uk/ files/file48018.pd

31 Ibid 

Published by the Sustainable Development Commission @ May 2009

Prepared by Farooq Ullah, Anne-Marie Shields and Jennifer Crees of the SDC Watchdog Team

With special thanks to Minas Jacob, Rebecca Willis, Andrew Lee, Jonathon Porritt, Kay West, Rhian Thomas, Mariam Saleemi, Matt Greaves, Tom Rumsey, Christina Wadley,

Fiona MacKenzie, Elena Olloqui and Sarah Skinner.

Art Direction Andy Long, Design Awake Imaging

Photography @ Jerome Dutton 
Sustainable

Development Commission

www.sd-commission.org.uk

\author{
England \\ (Main office) \\ 55 Whitehall \\ London SW1A 2HH \\ 02072708498 \\ enquiries@sd-commission.org.uk
}

Scotland

Osborne House

1 Osbourne Terrace, Haymarket

Edinburgh EH12 5HG

01316251880

Scotland@sd-commission.org.uk

www.sd-commission.org.uk/scotland
Wales

Room 1, University of Wales,

University Registry, King Edward VII Avenue,

Cardiff, CF10 3NS

02920376956

Wales@sd-commission.org.uk

www.sd-commission.org.uk/wales

\section{Northern Ireland}

Room E5 11, OFMDFM

Castle Buildings, Stormont Estate,

Belfast BT4 3SR

02890520196

N.Ireland@sd-commission.org.uk

www.sd-commission.org.uk/northern_ireland 